\title{
Vegetation-environment relationships of an inland boreal salt pan
}

\author{
by
}

CHARLES A. BURCHILL

A thesis presented to the University of Manitoba in partial fulfillment of the requirements for a degree of Master of Science in the Faculty of Graduate Studies

Department of Botany

University of Manitoba

Winnipeg, Manitoba R3T 2N2

(c) C.A. Burchill, 1991 
Canadian Theses Service Service des thèsés canadiennes

Otlawa. Canada

KIA ON4

The author has granted an irrevocable nonexclusive ficence allowing the National Library of Canada to reproduce, loan, distribute or sell copies of his/her thesis by any means and in any form or format, making this thesis available to interested persons.

The author retains ownership of the copyright in his/her thesis. Neither the thesis nor substantial extracts from it may be printed or otherwise reproduced without hiș/her permission.
L'auteur a accordé une licence irrévocable et non exclusive permettant à la Bibfiothèque nationale du Canada de reproduire, prêter. distribuer ou vendre des coples de sa thèse de quelque manière et sous quelque forme que ce soit pour mettre des exemplaires de cette thèse à ta disposition des personnes intéressées.

L'auteur conserve la propriété du droit d'auteur qui protège sa thèse. Ni la thèse ni des extraits substantiels de celle-ci ne doivent être imprimés ou autrement reproduits sans son autorisation.

ISBN $\quad 0-315-76672-7$

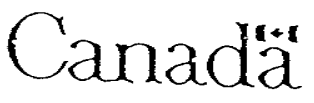




\title{
VEGETATION-ENVIRONMENT RELATIONSHIPS OF AN \\ INLAND BOREAL SALT PAN
}

BY

CHARLES A. BURCHILL

\begin{abstract}
A thesis submitted to the Faculty of Graduate Studies of the University of Manitoba in partial fulfilment of the requirements of the degree of
\end{abstract}

\section{MASTER OF SCIENCE}

\section{() 1991}

Permission has been granted to the LIBRARY OF THE UNIVERSiTY OF MANITOBA to lend or sell copies of this thesis. to the NATIONAL LJBRARY OF CANADA to inicrofilm this thesis and to lend or sell copies of the film, and UNIVERSITY MICROFILMS to publish an abstract of this thesis.

The author reserves other publication rights, and neither the thesis nor extensive extracts from it may be printed or otherwise reproduced without the author's written permission. 


\section{Contents}

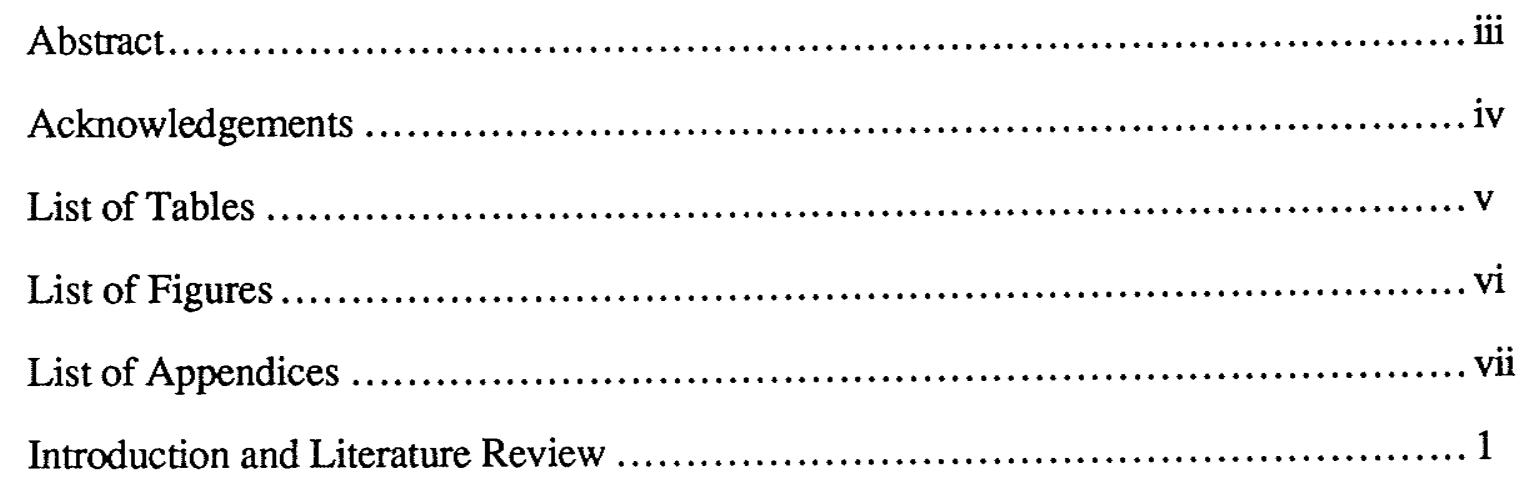

1.1 Distribution and Characterization of Inland Saline Ecosystems in North

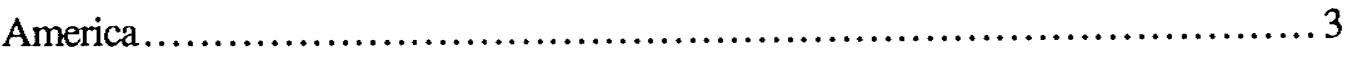

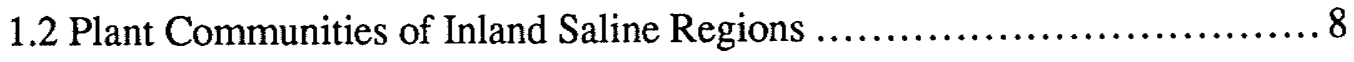

1.2.1 Succulent Communities ...................................... 9

1.2.2 Graminoid Communities .................................... 9

1.2.3 Shrub Communities..................................................12

1.2.4 Saline Lakes and Ponds ..................................... 13

1.3 Temporal Dynamics of Inland Saline Plant Communities ................. 13

1.4 Vegetation Zonation .................................................. 16

1.5 Salt tolerance .......................................................... 17

1.5.2 Accumulation and Compartmentalization of Salts.................20

1.5.3 Accumulation of Organic Solutes ............................. 22

Study area, Survey Design and Data Analysis................................... 28

2.1 Saline Areas of Manitoba .............................................. 28

2.1.1 Hudson Bay Coastline..................................................28

2.1.2 Salt Pans and Flats in South-Western Manitoba........................ 28

2.1.3 Sodium Chloride Seeps and Springs of the Winnipegosis and

Dawson Bay Formations .......................................... 29 


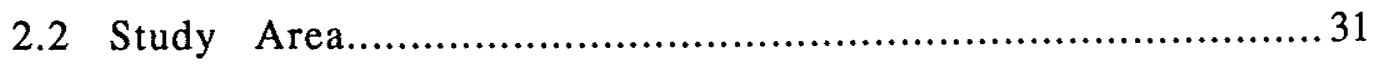

2.2.1 Site Description........................................................ 31

2.2 .2 Climate ...................................................... 34

2.2.3 Vegetation and Physiognomy.......................................... 34

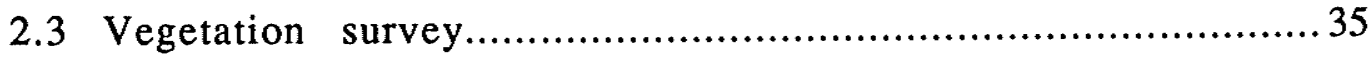

2.4 Soil Sample Collection and Analysis.................................... 37

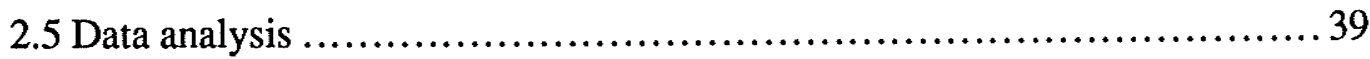

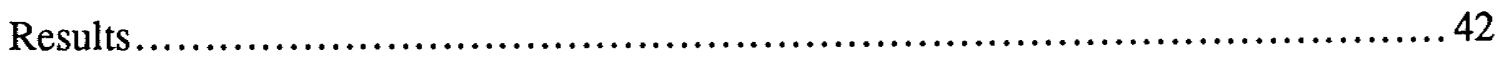

3.1 Vegetation Associations..................................................... 42

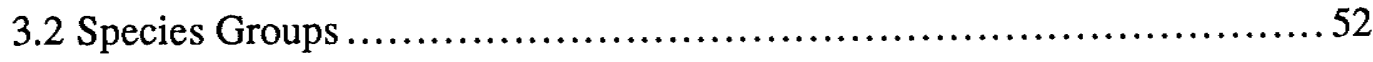

3.3 Relationship Between Vegetation Associations and Species Groups........... 53

3.4 Vegetation-Environment Relationships ................................ 54

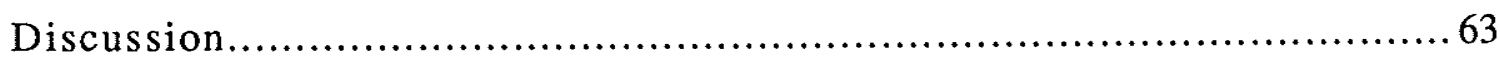

4.1 Plant Communities of Inland Saline Sites .............................6 63

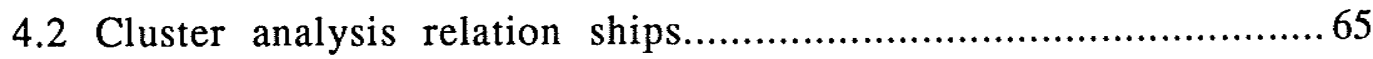

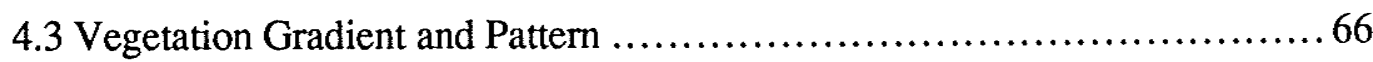

4.4 Trends in Species Richness and Diversity Along the Salinity Gradient.......69

4.5 Spatial and Temporal Dynamics of Inland Saline Habitats ................. 71

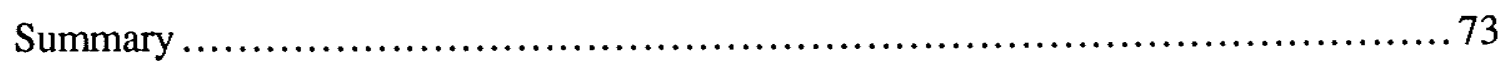

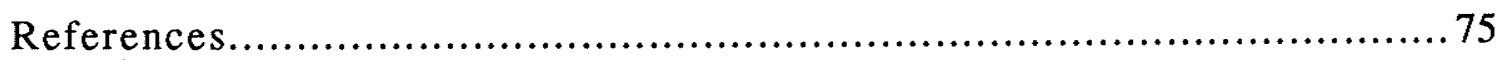




\begin{abstract}
Vegetation composition and community structure of boreal inland salt pans near the shore of Dawson Bay, Lake Winnipegosis, Manitoba were examined. Eight vegetation associations and eight species groups were described from the site. Most of the associations were dominated by a single species. Non-metric multidimensional scaling was used to ordinate the vegetation data, the resulting two dimensional ordination was compared to eight environmental variables using canonical correlation analysis. Salinity was found to be the over-riding factor causing a strong vegetation gradient. However soil factors could only account for part of the change in vegetation pattern around the salt flats. It is suggested that further ordering and formation of vegetation boundaries could arise through interspecific competition and displacement mediated by differences in salt tolerance.
\end{abstract}




\section{Acknowledgements}

I would like to thank C. Wilkes, R. Garrod, G. Jones, A. Mcllraith and Dr. T. Booth for help in collecting and processing the data; the staff of the Overflowing River service station for their hospitality and support; Rob Eilers from Soil survey of Manitoba for his input and interest; the academic and support staff of the Department of Botany for help with equipment and ideas. This research was supported by an NSERC operating grant to N.C. Kenkel and two Northern Studies travel grants. I would especially like to thank Kathy for putting up with me during all the times I spent in the field. I would like finally to say that working on a thesis is a very long difficult job with many rewards, the least of which is getting a degree at the end. 


\section{List of Tables}

1.1 Presence-absence data for 37 species in 10 different saline areas of North America ... 6

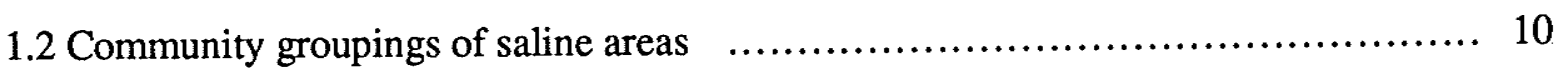

1.3 Optimal salinities $(\mathrm{NaCl})$ for growth of a variety of halophytes .................. 19

1.4 Occurrence of suspected osmotica in coastal halophytes .................................. 24

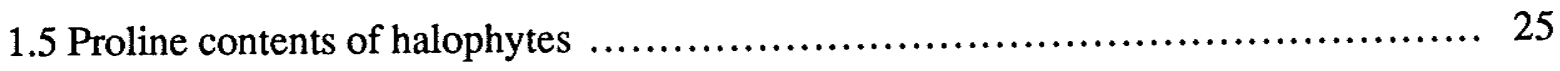

3.1 Soil and environmental factors (means \pm 1 s.d.) for the eight vegetation associations . 45

3.2 Vegetation characteristics (means \pm 1 s.d.) for the eight vegetation associations ...... 46

3.3 Results of Scheffe's multiple comparison test .............................. 51

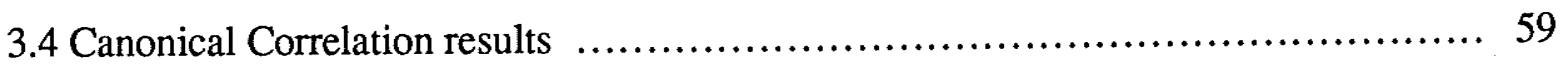




\section{List of Figures}

1.1 Saline sites studied in North America ......................................... 5

1.2 Cluster analysis of 10 different saline areas around North America..................... 7

2.1 Approximate extent of salt deposits in western Canada.............................. 30

2.2 Overview of Site I ...................................................... 32

2.3 Lakes Winnipeg, Manitoba and Winnipegosis................................... 33

2.4 Enlarged view of the study area with the baseline trasects marked................... 36

3.1 Sum of squares agglomerative cluster analysis of the 1176 quadrats ................ 44

3.2 Mean percent cover ( \pm 1 s.e.) of species in each of the eight vegetation associations

3.3 The relationship between mean species richness and mean soil salinity .............. 49

3.4 Sum of squares agglomerative cluster analysis of the 37 species...................... 56

3.5 Two-dimensional concentration analysis ordination of the eight vegetation associations and eight species groups ........................................... 57

3.6 Two-dimensional nonmetric multidimensional scaling ordination of 135 quadrats ..... 58

3.7 Boxplots summarizing salinity variation among associations $\ldots \ldots \ldots \ldots \ldots \ldots \ldots \ldots \ldots .60$

3.8 Mean percent cover ( \pm 1 s.e.) vs. soil salinity class for the nine most frequently

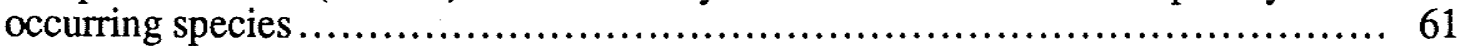

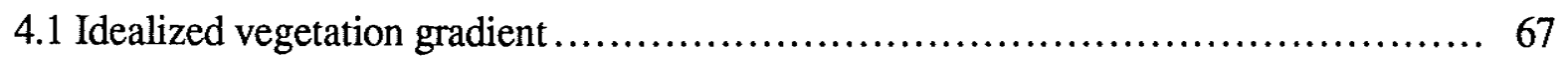

4.2 Theoretical model of how three species would respond with out competition under salinity stress and with competition and salinity stress 


\section{List of Appendices}

Appendix A. Halophyte communities of North America........................... 82

Appendix B. Proposed successional sequences of saline vegetation .................. 89

Appendix C. Complete species list of the saline community and surrounding area......... 95

Appendix D. Summary of environmental variables among associations ................. 98 


\section{Chapter 1 \\ Introduction and Literature Review}

Although the coastal salt marshes of North America have been intensively studied (Haines \& Dunn 1976, Odum 1988), inland saline systems have received comparatively little attention. In any saline environment, plants must adapt osmotically to high concentrations of certain ions in the soil (Jefferies 1981, Yeo 1983). However, a major difference in environmental conditions between coastal and inland systems arises from the absence of tidal effects in the latter. Plant species of coastal marshes must adapt to predictable tidal rhythms which impose strong environmental gradients (Haines \& Dunn 1976), those of inland habitats are subject to highly variable soil salinity concentrations and periods of desiccation (Ungar 1967, 1970, 1972, 1974a). This is particularly true in continental regions where annual precipitation is low, limited to particular seasons, and shows considerable variation from year to year (Borchert 1971). Inland halophytes are also subjected to occasional submergence following spring runoff or heavy rains. The environment of an inland saline habitat is therefore somewhat less predictable than that of most coastal salt marshes, both seasonally and from year to year.

North American inland saline habitats are most commonly encountered in areas where potential evapotranspiration exceeds precipitation (McKell, Goodin \& Jefferies 1986). In the United States, the plant communities of saline environments have been described from both prairie and desert regions (Ungar 1974a Brotherson and Rushforth 1987). In Canada, saline soils occur in the drier, southern prairies (McKell, Goodin \& Jefferies 1986). The only published surveys of associated plant communities are from southern Alberta (Keith 1958) and Saskatchewan (Dodd \& Coupland 1966). Most of the North American studies

are descriptive in nature, with plant communities being delineated either by visual inspection or using a preexisting classification system. All have suggested that species are distributed along a salinity gradient in a manner reflecting their degree of salt tolerance, but 
few studies have included detailed quantitative soil analyses. Furthermore, multivariate statistical methods have rarely be used to objectively delineate vegetation types, describe trends, and examine vegetation-environment relationships. More detailed studies of these ecosystems are required, using random sampling and multivariate methods to objectively delineate vegetation types, describe spatial trends, and examine vegetation-environmental relationships. Furthermore, the saline ecosystems of Canada (particularly those of northern regions) deserve greater attention.

These ecosystems appear to be characterized by dynamic vegetation change, with plant communities and vegetation zones advancing and retreating in response to changes in soil salinity over time. A linear successional sequence involving successive replacement of salttolerant species by less tolerant ones appears to be less common, and can only be expected to occur in areas where salts are removed from the soil through leaching or by some other mechanism. The clear vegetation zonation often seen in inland saline ecosystems in North America is probably a result of competitive interactions between species, with more salttolerant species being relegated to more saline areas through competitive exclusion (Kenkel, McIraith,Burchill \& Jones 1990).

The majority of inland saline habitats in Canada are internal drainage basins where evaporation results in surficial salt deposits. Seepage of saline groundwater into such depressions may also occur, and dryland farming practices may further increase soil salinity (McKell, Goodin \& Jefferies 1986). The resulting salt pans or 'playas' are common throughout the prairie. The salts are generally sodium and magnesium sulphates, though specific ionic composition varies widely (Henry, Harron \& Flaten 1987). Surficial salts may also occur naturally in areas where saline groundwater percolates to the surface. A number of studies have described the vegetation of artesian saltwater discharge sites in the United States (e.g. Chapman Dunevitz \& Kuhn 1985; Brotherson and Rushforth 1987). Saline springs also occur in Canada, but the vegetation of such sites has not been investigated in detail. Spring-fed saline flats are particularly well developed near the 
western shore of Lake Winnipegosis in west-central Manitoba, and along the Slave and Athabasca Rivers in northeastern Alberta (Pearson 1963).

Several undisturbed salt pans near Dawson Bay, Lake Winnipegosis, Manitoba were investigated. The objectives of this study were (a) to provide an objective classification for the vegetation associations in a saline community; (b) to describe the dominant species groups; (c) to relate the vegetation associations and species distributions to existing environmental gradients; and (d) to propose testable hypotheses regarding the distribution and zonation patterns of species in inland saline habitats.

\subsection{Distribution and Characterization of Inland Saline Ecosystems in North America}

Within a site, the spatial distribution of inland halophytic species appears to be determined primarily by soil salinity, with species grading from the most salt-tolerant to the least salt-tolerant. In many areas soil moisture plays a secondary role. Although halophytes are limited to saline environments, their range extends from dry desert to moist forest ecosystems (Ungar 1974b). This suggests either a requirement for salts or a tolerance to salt coupled with an inability to compete with glycophytic species. Halophyte communities have been reasonably well documented in the western United States, with some studies being conducted in the midwestern U.S.A and the Canadian prairies. This section summarizes previous studies of the plant communities of inland saline regions in North America. Community composition, temporal dynamics, and vegetation zonation are considered.

A survey of the literature indicated that inland saline systems in the United States are generally restricted to drier regions west of the Mississippi River (Figure 1.1). Plant communities of saline areas have been described from Utah (Schaffner 1889; Flowers 1934; Bolen 1964;Ungar 1967, 1968; Skougard \& Brotherson 1979; Shupe, Brotherson \& Rushforth 1986), Kansas (Ungar 1965, 1967), Nebraska (Ungar, Hogan \& McClelland 
1969), Oklahoma (Ungar 1968), Colorado (Ungar 1974), California (Brotherson \& Rushforth 1987), and South Dakota (Ungar 1970). Inland saline regions in Canada are generally restricted to drier regions of the prairie provinces, particularly in Alberta (Keith 1958) and Saskatchewan (Dodd \& Coupland 1966; Dodd, Rennie \& Coupland 1964). The only description of inland saline vegetation east of the Mississippi-Red River basin is from Michigan (Chapman, Dunevitz, \& Kuhn 1985).

Data on the frequency of occurrence of thirty seven vascular plant species in 18 different North American sites was collated and summarized at 10 different geographical locations (Table 1.1) The data was obtained from Ungar (1974) and from the current study. This data was used to examine the similarity and differences between many of the saline areas in North America. Species included in this collation exhibited at least a 50\% relative frequency in the described communities. A sum of squares cluster analysis (SAS 1985) using the Ochiai coefficient (Kenkel \& Booth 1987) was used to delineate major divisions between the saline sites. Cluster analysis revealed four main site groups (Figure 1.2): 1. Nebraska, Kansas, Oklahoma; 2. Colorado, Utah, California; 3. North Dakota, South Dakota, Saskatchewan; 4. Manitoba. Manitoba comes out as an individual group when compared to other studied saline sites of north America. Species such as Poa arida, Sporobolus airoides, S. texanus and Tamarix pentandra were found only on the southern sites. Spartina gracilis, Triglochin maritima, Puccinellia nuttalliana, and Sonchus arvensis are more common on northern sites. Two species that are very common on the Manitoba site but have not been recorded in the other inland saline sites are Calamagrostis inexpansa and Agropyron trachycaulum. These two species may occur in other sites but may be rare. 


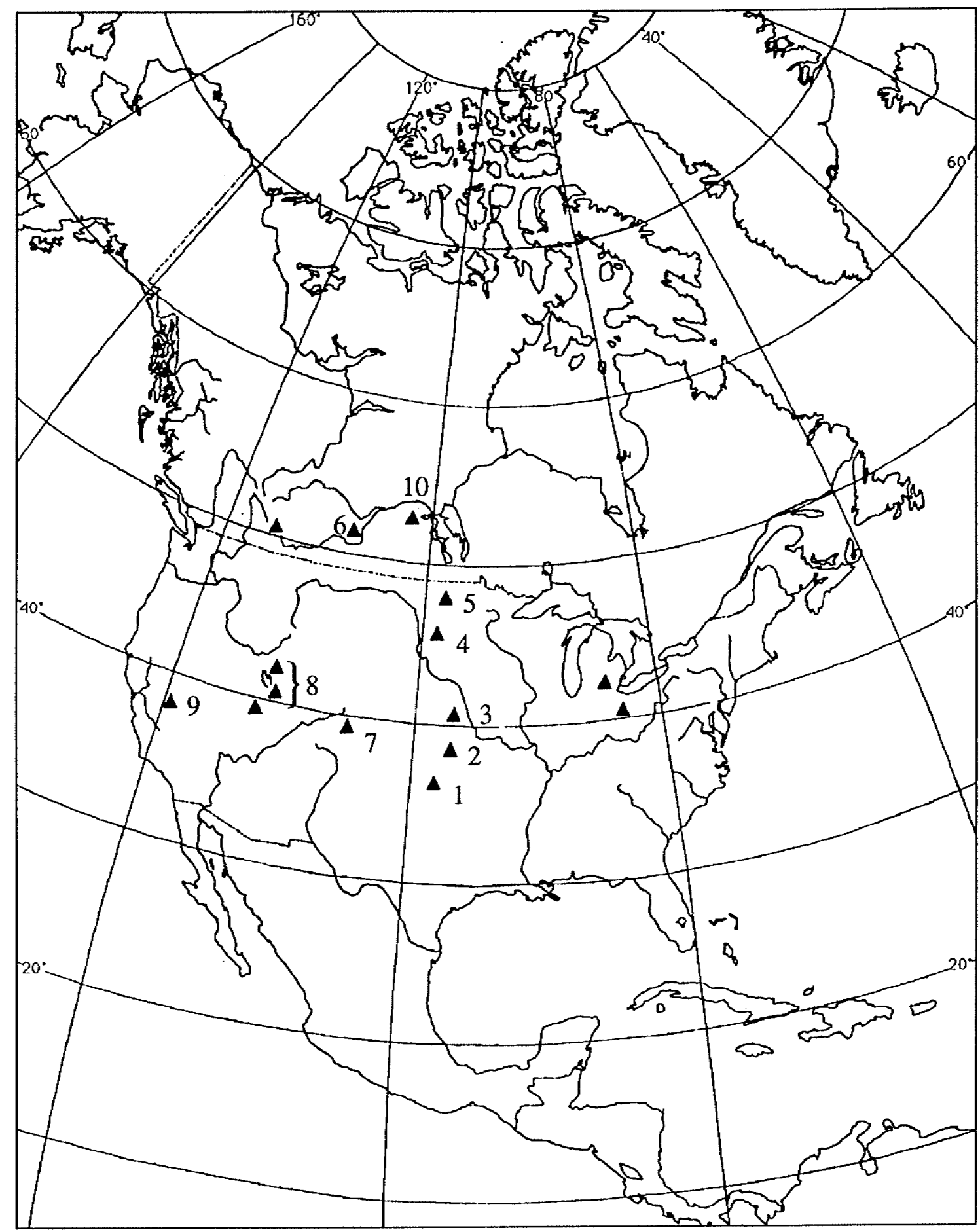

Figure 1.1 Saline sites studied in North America (triangles represen locations). Adapted from Booth 1971 
Table 1.1 Presence-absence data for 37 species in 10 different saline areas of North America. Species with over 50\% cover in any individual community (association) are included. Data from Ungar (1974)

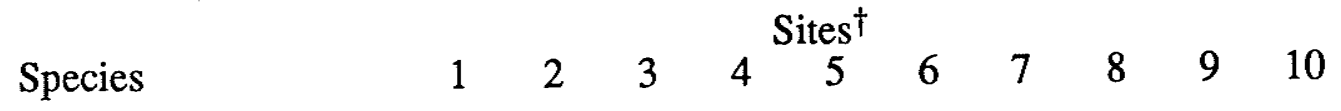

\begin{tabular}{|c|c|c|c|c|c|c|c|c|c|c|}
\hline Agropyron smithii & 1 & 1 & 1 & 1 & 1 & 1 & 1 & 0 & 0 & 0 \\
\hline Agropyron trachycaulum & 0 & 0 & 0 & 0 & 0 & 0 & 0 & 0 & 0 & 1 \\
\hline Allenrolfea occidentalis & 0 & 0 & 0 & 0 & 0 & 0 & 0 & 1 & 1 & 0 \\
\hline Ambrosia artemesifolia & 0 & $\mathbf{0}$ & 1 & 1 & 0 & 0 & 1 & $\mathbf{0}$ & 1 & 0 \\
\hline Ambrosia psilostachya & 0 & 1 & 0 & 0 & 1 & 0 & 1 & 0 & 1 & 1 \\
\hline Atriplex artentea & 1 & 1 & 1 & 1 & 1 & 1 & 1 & 1 & 1 & 0 \\
\hline Atriplex patula var. hastata & 0 & 1 & 1 & 1 & 1 & 1 & 1 & 1 & 1 & 1 \\
\hline Calamagrostis inexpansa & 0 & 0 & 0 & 0 & 0 & 0 & 0 & 0 & 0 & 1 \\
\hline Chenopodium rubrum & 0 & 0 & 0 & 1 & 0 & 1 & 1 & 1 & 1 & 0 \\
\hline Distichlis stricta & 1 & 1 & 1 & 1 & 1 & 1 & 1 & 1 & 1 & 1 \\
\hline Eleocharis palustris & 1 & 1 & 1 & 1 & 1 & 1 & 1 & 1 & 1 & 1 \\
\hline Hordeum jubatum & 1 & 1 & 1 & 1 & 1 & 1 & 1 & 1 & 1 & 1 \\
\hline Iva annua & 0 & 1 & 1 & 1 & 1 & 0 & 0 & 0 & 0 & 0 \\
\hline Kochia scoparia & 1 & 1 & 1 & 1 & 1 & 0 & 1 & 0 & 0 & 0 \\
\hline Phragmites communis & 0 & 0 & 1 & 1 & 1 & 1 & 1 & 1 & 1 & 1 \\
\hline Poa arida & 1 & 1 & 1 & 1 & 1 & 0 & 1 & 0 & $\mathbf{0}$ & $\mathbf{0}$ \\
\hline Polygonum aviculare & 1 & 1 & 1 & 1 & 1 & 0 & 1 & 0 & 1 & 0 \\
\hline Potamogeton pectinatus & 1 & 1 & 1 & 1 & 1 & 1 & 1 & 1 & 1 & 0 \\
\hline Puccinellia nuttalliana & 0 & 0 & 0 & 1 & 1 & 1 & 1 & 1 & 1 & 1 \\
\hline Ranunculus cymbalaria & 0 & 0 & 0 & 1 & 1 & 1 & 1 & 0 & 1 & 1 \\
\hline Rumex crispus & 0 & 1 & 1 & 1 & 1 & 0 & 1 & 1 & 1 & 0 \\
\hline Rupia maritima & 1 & 1 & 1 & 1 & 1 & 1 & 1 & 1 & 1 & 0 \\
\hline Salicornia rubra & 0 & 1 & 1 & 1 & 1 & 1 & 1 & 1 & 1 & 1 \\
\hline Scirpus americanus & 1 & 1 & 1 & 1 & 1 & 1 & 1 & 1 & 1 & 1 \\
\hline Scirpus paludosus & 1 & 1 & 1 & 1 & 1 & 1 & 1 & 1 & 1 & 1 \\
\hline Sesuvium verrucosum & 1 & 1 & 0 & 0 & 0 & 0 & 1 & 1 & 1 & 0 \\
\hline Sonchus arvensis & 0 & 0 & 0 & 1 & 1 & 1 & 1 & 0 & 0 & 1 \\
\hline Spartina gracilis & 0 & 0 & 0 & 0 & 1 & 1 & 1 & 1 & 1 & 1 \\
\hline Spartina pectinata & 0 & 1 & 1 & 1 & 1 & 1 & 1 & 1 & 0 & 0 \\
\hline Sporobolus airoides & 1 & 1 & 1 & 0 & 0 & 0 & 1 & 1 & 1 & 0 \\
\hline Sporobolus texanus & 1 & 1 & 1 & 0 & 0 & 0 & 1 & 1 & 0 & 0 \\
\hline Suaeda depressa & 1 & 1 & 1 & 1 & 1 & 1 & 1 & 1 & 1 & 1 \\
\hline Tamarix pentandra & 1 & 1 & 0 & 0 & 0 & 0 & 1 & 0 & 1 & 0 \\
\hline Triglochin maritima & 0 & 0 & 0 & 0 & 1 & 1 & 1 & 1 & 1 & 1 \\
\hline Typha angustifolia & 1 & 1 & 1 & 1 & 1 & 1 & 1 & 1 & 1 & 0 \\
\hline Typha latifolia & 1 & 1 & 1 & 1 & 1 & 1 & 1 & 1 & 1 & 0 \\
\hline Aster spp. & 1 & 1 & 1 & 1 & 1 & 1 & 1 & 1 & 1 & 1 \\
\hline
\end{tabular}

† Sites: 1. Oklahoma, 2. Kansas, 3. Nebraska, 4. South Dakota, 5. North Dakota, 6. Saskatchewan, 7. Colorado, 8. Utah, 9. California, 10. Manitoba 


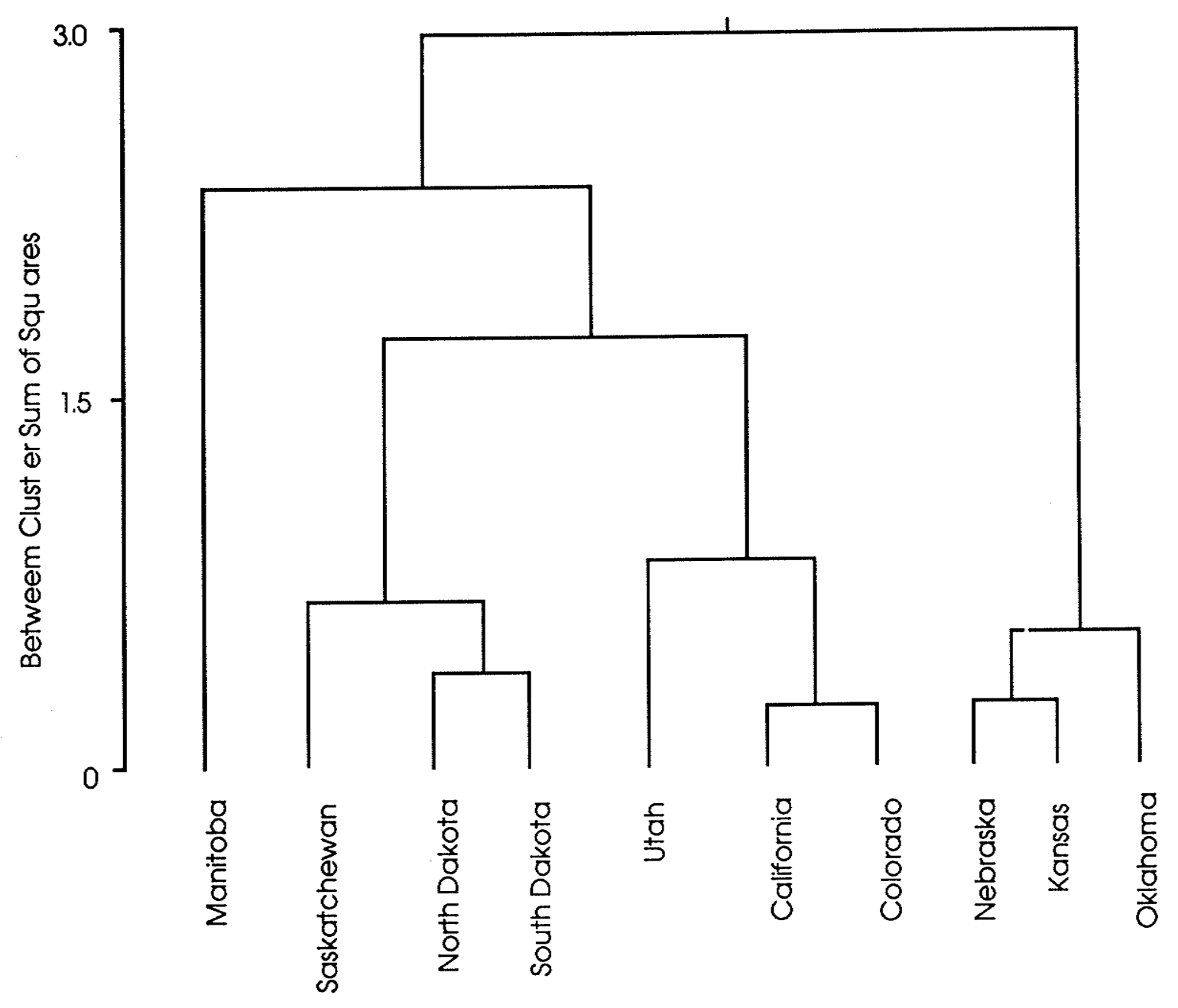

Figure 1.2 Cluster analysis of 10 different saline areas around North America. 


\subsection{Plant Communities of Inland Saline Regions}

It should be noted from the outset that most studies dealing with plant communities of inland saline areas are descriptive. Most have described the communities in terms of species occurrence (presence-absence) and/or species 'associations'. The plant communities themselves have generally been delineated either by visual inspection (c.f. the Braun-Blanquet school of vegetation science see Mueller-Dumbois \& Ellenberg 1974) or by using a classification system suggested by other workers (that is, previously established community types). Only a few of these studies have included quantitative analyses of soil salinity and chemistry.

A complete list of plant communities of inland saline regions in North America which have been described over the last 90 years can be found in Appendix 1. In general there is a clear sequence of communities from high to low salt levels. The highly salt tolerant communities tend to be dominated by therophytes, and have a very low species richness (usually 1-3 species) and plant density (Ungar 1972). With decreasing salinity, hemicryptophytes and cryptophytes show increased dominance and there is a dramatic

increase in species richness and plant density (Dodd \& Coupland 1966; Ungar 1965, 1967, $1968,1972,1974 a)$.

Although soil salinity appears to have the greatest influence on species distribution, soil moisture may also be important in some areas (Ungar 1972). According to Ungar (1972), the type of salt does not appear to be as important as the overall osmotic potential of the soil. Competition between saline species in conjunction with soil salinity may be the major factor in determining the spatial arrangement of species and communities in saline areas.

Ungar (1974) suggested a general classification of North American saline communities based on four broad categories: succulent communities, graminoid communities, shrub 
communities, and submerged communities (Table 1.2). These general community groupings are discussed in more detail below.

\subsubsection{Succulent Communities}

Such communities have low species richness, and are usually dominated by plants exhibiting the therophyte life-form (Ungar 1965, 1972). Since the osmotic potential of many salt flat systems can be extremely variable over the growing season (Ungar 1970, 1972), these areas are typically dominated by annual plants with highly salt tolerant seeds and high germination rates under optimal (low salinity) conditions. Dominant species include Salicornia spp., Suaeda depressa, Allenrolfrea occidentalis, and Sesuvium verrucosum. Several authors have indicated that the seed of many of the species remain viable even after long periods at high salinity (Macke \& Ungar 1971; Ungar 1962, 1967, 1982, 1987). Species richness in these areas generally varies between 1 and 3 species, although Dodd \& Coupland (1966) include 12 species as growing within this zone. Salt content of the soils vary between $1.9 \%$ and $6.26 \%$ (total salts per unit dry mass of soil).

\subsubsection{Graminoid Communities}

These communities are usually dominated by grasses (the exceptions being the Triglochin and Scirpus communities) and have low to moderate species richness. Hemicryptophytes and cryptophyte life forms predominate. Salt levels vary widely (<.05\% to 6.96\%) among this group of communities. Soil salinity levels within graminoid communities are less seasonally variable than those in the succulent communities. Ungar (1972) includes six different communities in this group, as outlined below. 
Table 1.2 Community groupings of saline areas (taken from Ungar 1974a)

1. Succulent communities

Allenrolfrea occidentalis

Salicornia rubra

Suaeda depressa

Sesuvium verrucosum

2. Graminoid communities

Distichlis stricta

Puccinellia nuttalliana

Triglochin maritima

Sporobolus airoides

Hordeum jubatum

Scirpus paludosus

3. Shrub communities

Tamarix pentandra

Sarcobatus vermiculatus

Atriplex confertifolia

Kochia sp.

Eurotia lanata

Chrysothamnus nauseousus

4. Submerged communities

Potamogeton-Chara-Ruppia 
Distichlis stricta often forms monodominant communities when the soil salinity is very high (Ungar 1974). At lower salinities it may associate with Hordeum jubatum (Ungar 1967,1968, 1970), Puccinellia nuttalliana (Dodd, Rennie \& Coupland 1964), Agropyron smithii (Dodd Rennie \& Coupland 1964; Ungar 1970), Spartina pectinata (Ungar 1965) and Scirpus paludosus (Ungar 1965). D. stricta is widely distributed in North America, occurring from the Gulf of Mexico to northern Alberta, and is reported to be one of the most salt tolerant grasses. It has been found growing in soils with salinities ranging from a high of $0.03 \%$ (Ungar 1970) to $6.96 \%$ (Bolen 1964). In highly saline soils a dwarf form of the species has been noted (Ungar 1965).

The Puccinellia nuttalliana community is also widely distributed, but occurs most frequently in the western and northern areas of the North American great plains. This species is also highly salt tolerant; usually Salicornia rubra, Suaeda depressa, and Triglochin maritima are the only species that grow in more saline soils. This community type generally consists of almost pure stands of $P$. nuttulliana, although small amounts of Salicornia rubra, Distichlis stricta , Agropyron smithii, Triglochin maritima, Hordeum jubatum and Suaeda depressa may also occur. Macke \& Ungar (1971) have shown that while this species is stimulated by low salt levels, it nonetheless thrives under non-saline conditions. Puccinillia nuttalliana communities usually occur on soils with salinities ranging from $0.7 \%$ to $2.8 \%$.

The Triglochin maritima community is included in the graminoid group because its growth habit is similar to that of grasses. It is generally found in areas with a high water table, and occurs on both saline and non-saline soils. The community has a higher species diversity than any of the other communities (Ungar 1974). Community associates include Distichlis stricta, Hordeum jubatum, Eleocharis palustris, Poa canby, Chenopodium rubrum, Suaeda erecta, Atriplex hastata, Halerpestes cymbalaria, Glaux maritima, Juncus ater, and Sonchus uliginos (Ungar 1974; Dodd \& Coupland 1966). This community-type generally forms on soils with salt contents of 1.6 to $2.1 \%$. 
Sporobolus airoides usually grows in non-saline areas but may be a secondary invader of saline soils, particularly in high water years when soil salinity is decreased. The roots then form a hummock which is invaded by prairie species. This pattern may be cyclical if the salinity increases again or may be the first stage in a secondary succession to prairie vegetation (Ungar 1974).

Hordeum jubatum communities occur on moderately saline soils throughout western North America. It may occur in relatively pure stands or with co-dominants Distichlis stricta, Atriplex patula var. hastata, and Iva annua (Keith 1958; Dodd \& Coupland 1966; Ungar 1965, 1967; Ungar, Hogan \& McClelland 1969). Ungar (1974a) notes that some Hordeum jubatum communities show a seasonal aspect. For example, in Kansas and Nebraska $H$. jubatum often dominates in the spring, but by late summer or fall Iva annua and Atriplex patula var. hastata become increasingly dominant. Hordeum. jubatum communities generally occur on soils ranging in salinity from zero to $1.1 \%$.

The final graminoid group is dominated by Scirpus paludosus. Like Triglochin, this species is not a grass but has a similar growth form. This community is mainly restricted to the borders of saline lakes and wet depressions and shallow ponds in western North America (Lieffers 1981, Lieffers \& Shay 1982); it does not occur in drier areas. It generally occurs in nearly pure stands, but may be found with Distichlis stricta, Scirpus americanus, Suaeda depressa, Atriplex patula var. hastata, and Hordeum jubatum (Ungar 1974). The limiting soil salinity appears to be $1.5 \%$.

\subsubsection{Shrub Communities}

On saline soils in North America halophytic shrubs are mainly limited to the salt deserts of the southern and central United States. These communities are dominated by woody salt tolerant species such as Tamarix pentandra, Sarcobatus vermiculatus, Atriplex confertifolia, Kochia sp., Eurotia lanata, and Chrysothamnus nauseousus (Ungar 1972). 
The shrub S. vermiculatus was found in southern Saskatchewan by Dodd and Coupland (1966), but they did not distinguish a separate shrub community.

\subsubsection{Saline Lakes and Ponds}

Inland saline lakes and ponds contain few vascular plants. They are often dominated by the algae Chara, Nitella, and Tolypella. The only fully submerged vascular plants usually found in saline waters are Ruppia maritima and Potamogeton spp. (Ungar 1974). In Canada saline lakes are found in southern Saskatchewan and southern Alberta (Hammer 1978).

\subsection{Temporal Dynamics of Inland Saline Plant Communities}

A number of authors have proposed successional sequences for plant communities on saline soils in western North America (see Appendix B). Most of the schemes are unidirectional and proceed in a linear sequence from higher to lower salinity over time. Retrogressive schemes (proceeding from low to higher salinity) have also been proposed, but more recent schemes have largely abandoned the concept of a unidirectional successional sequence in favour of dynamic schemes in which the vegetation tracks changes in environmental conditions over time.

Ungar (1972) proposed a broad-based dynamic scheme for all North American inland saline regions (Appendix B) which attempted to incorporate most of the descriptive work done on inland salt marshes prior to 1972 . There are two pioneer, or initial, stages: the salt pan and the salt pond. A series of wet years may result in a decrease in the salinity of a salt pan, resulting in replacement of less salt-tolerant communities and the eventual formation of a non-saline prairie. However, communities may regress back to those characteristic of salt pans if salinity increases. This could occur, for example, following a period of dry years. 
The salt pond will change in a similar way, forming a non-saline marsh which gradually fills in and develops into a non-saline prairie community.

Pioneer successional species on inland saline pans are usually annual succulents in the genera Sesuvium, Suaeda, Salicornia and Allenrolfrea (Flowers 1934; Dodd \& Coupland 1966; Ungar 1965,1966,1967,1968,1970; Ungar, Hogan \& McClelland 1969). Salt tolerant grasses such as Distichlis stricta or Puccinellia nuttalliana may also be primary invaders. The highly salt tolerant Distichlis stricta is often associated with Atriplex patula var. hastata, Atriplex argentea, Hordeum jubatum, Poa arida and Aster exilis (Flowers 1934; Ungar 1965, 1967,1968, 1970). In the southwestern United States Sporobolus airoides and $S$. texanus may be prominent secondary invaders (Ungar 1965,1968). Associated with S. airoides are D. stricta, Ambrosia psilostachya, Aster ericoides, Chenopodium leptophyllum, Tamarix pentandra and Hordeum jubatum. In more northern areas Puccinellia nuttalliana dominates the pioneer communities of moist, saline soils (Dodd \& Coupland 1966; Ungar 1970). Associated species include Salicornia rubra, D. stricta, H. jubatum, and Suaeda depressa. Triglochin maritima is prevalent in the northern and western parts of the prairies in low moist areas and is commonly associated with $P$. nuttalliana, D. stricta and and H. jubatum (Keith 1958; Dodd \& Coupland 1966; Ungar 1974). Triglochin maritima will grow in areas with high salinities, but is also found on wet non-saline soils.

In northern regions a further reduction in soil salinity results in the formation of a prominent zone dominated by Hordeum jubatum and its associates D. stricta, Iva annua or Atriplex patula var. hastata (Keith 1958; Dodd \& Coupland 1966). In areas of still lower salinity, less salt-tolerant species such as Agropyron spp. dominate (Dodd \& Coupland 1966). In southern areas of the prairie, hummocks formed by Sporobolus airoides are invaded by prairie species to form a terminal successional stage (Ungar 1965, 1968). In the southern salt deserts Distichlis stricta meadows are later invaded by 
Sporobolus spp. or salt-tolerant shrubs, eventually leading to mixed shrub and bunch grass communities (Flowers 1934).

In western North America saline lakes are dominated by Potamogeton pectinatus and Ruppia maritima (Flowers 1934; Ungar 1965; Ungar, Hogan \& McClelland 1969). As the lake fills in or dries, this submerged stage is replaced by a emergent macrophyte stage in which Scirpus paludosus, Scirpus americanus, Eleocharis spp. and other species dominate (Ungar 1972). Further reductions in salinity and soil water levels eventually lead to the development of a climax prairie community (Ungar 1965,1970,1972).

Seed banks may play an important role in the development and perpetuation of communities in areas of high and variable salinity (Ungar 1987,1988). Interestingly, however, there appears to be no consistent relationship between the existing species composition of a given saline area and the corresponding seed bank (Ungar 1987). In general, communities dominated by annual halophytes contain a much larger seed bank than do perennial communities. This is not surprising, since seed dormancy is the only mechanism by which populations of annuals can be maintained over periods of adverse climatic conditions. This is important since there may be one or more very dry growing seasons in which little or no seed is set. Ungar (1982) found that seeds from one vegetation zone occurred in the seed banks of all other zones. Based on this observation, he hypothesized that with a change in soil salinity the community composition could change rapidly.

To conclude, most of the earliest proposed successional schemes were uni-directional, beginning with a pioneer community of succulent annuals on salt flats and eventually developing into a prairie community as soil salinity decreased. Regressional sequences, in which saline areas develop from non-saline or low-salinity prairie, are also possible (see Keith 1958). Such a sequence may occur if human activity causes an increase in salt levels, if a new source of salts develops, or under drought conditions. The scheme hypothesized and developed by Ungar $(1968,1972,1974)$ in which saline systems show a dynamic 
rather than a uni-directional sequence, particularly in the salt flats and highly salt-tolerant grass communities, appears to be the most realistic model of vegetation dynamics in these environments.

\subsection{Vegetation Zonation}

Most studies of the vegetation of inland saline areas in North America have noted the occurrence of clearly demarcated vegetation zones or edges, particularly in the more saline and species-poor areas of a salt pan. Interestingly, these marked discontinuities between plant communities often occurred in the absence of dramatic changes in soil or other environmental parameters (Ungar 1973,1974a). This differs from the situation in coastal salt marshes, in which tidal influences cause environmental edges at which abrupt changes in degree of inundation, salinity, and accumulation of organic wrack occur. In these situations, vegetational discontinuities may closely correspond to environmental edges (Bertness \& Ellison 1987). In inland salt pans, vegetation zones are usually dominated by one or two species, and communities are ordered in a sequence related to the salt tolerance of these dominants (Ungar 1979). With a reduced salinity across the gradient, halophytic species, which generally have a low intrinsic growth rate (Jefferies \& Rudwick 1984), are replaced by faster-growing glycophyte species, probably through the process of competitive exclusion (Ungar 1973). It has been noted that vegetation zonation in inland saline areas becomes less pronounced at low salinities (e.g. Flowers 1934; Ungar 1968, 1967, 1974; Skougard \& Brotherson 1979). This may be related to the increase in species diversity at lower salinities, which give rise to a continuum of vegetation variation along the gradient.

If environmental discontinuities are not the cause of vegetational discontinuities, then it seems likely that biotic processes may be involved. Recent models have indicated that competitive interactions may lead to the development of vegetational discontinuities along a 
continuous environmental gradient (e.g. Czaran 1989; Smith \& Huston 1989). A number of authors have suggested that competition may be an important factor in the development of vegetational discontinuities in saline ecosystem (Silander \& Antonovics 1982, Snow \& Vince 1984, Bertness \& Ellison 1987). Few studies have attempted to test this hypothesis. McMahon \& Ungar (1978) tested the effects of competition at a salt pan in Ohio using transplants of Atriplex triangularis . Seedlings were transplanted into cleared and uncleared plots in a Hordeum jubatum meadow and an adjacent salt pan. The growth of the salt pan transplants was greatly reduced, a result they attributed to high salt levels. Transplants in the cleared meadow plots had significantly higher survival rates than those from the uncleared meadow plots, leading the authors to conclude that the absence of $A$. triangularis in the untreated meadow stemmed from competition with Hordeum jubatum. Ungar, Benner \& McGraw (1979) investigated the factors influencing the distribution of Salicornia europaea in salt pans. This annual succulent species was transplanted into cleared and uncleared plots in five communities occurring along a salinity gradient: 'Pan', 'Salicornia', 'Atriplex', 'Hordeum', and 'Meadow' (order is from highest to lowest salinity). It was found that transplants into the 'Pan' and 'Meadow' zones had the highest mortality. Lowest seedling mortality and highest above-ground biomass production occurred in cleared plots from the 'Atriplex' and 'Hordeum' zones. Based on these results, they concluded that interspecific competition played a role in determining both the level of plant production and the distribution of species along the salinity gradient.

\section{$1.5 \underline{\text { Salt tolerance }}$}

Halophytic species generally employ a combination of mechanisms that allow them to survive and grow in saline environments. These mechanisms fall into two broad categories: (a) the avoidance of salt through regulation of the amount entering the plant through the endodermis: and (b) the accumulation of salts and/or osmotica to maintain an osmotic 
potential higher than that of the soil. The latter may be accomplished either by increasing the amount of solute within the cytoplasm or through the accumulation of ions within the vacuole and/or inter-cellular spaces. Production of organic solutes and accumulation of ions within the cell vacuole appears to be the most common method for maintaining an equilibrium between tissue osmotic potential and soil water potential.

Flowers, Troke \& Yeo (1977) indicate that many halophytes show an optimal growth rate in slightly to moderately saline culture solutions, suggesting a possible requirement for salts (Table 1.3). Although some studies suggest that halophytes show an increase in intrinsic growth rate in the presence of low salt levels, there are no known 'obligate' halophytes; all known salt tolerant higher plants retain the ability to grow and complete their life cycle in the absence of added salts (Barbour 1970; Flowers, Troke \& Yeo 1977). Greenway \& Osmond (1972) noted that higher plant cell enzymes show reduced activity when exposed to high levels of salts. Therefore in higher plants salts must be avoided or comparti.tentalized in intercellular spaces or vacuoles. 
Table 1.3. Optimal salinities $(\mathrm{NaCl})$ for growth of a variety of halophytes (after Flowers, Troke \& Yeo 1977).

\begin{tabular}{lc}
\hline \hline \multicolumn{1}{c}{ Species } & $\begin{array}{c}\text { Optimal salinity } \\
(\mathrm{mM})\end{array}$ \\
\hline Salicornia bigelovii & $\approx 170$ \\
S. europaea & $136-340$ \\
Suaeda depressa & 170 \\
S. maritima & $170-400+$ \\
S. vulgaris & 170 \\
Atriplex halimus & $6-120$ \\
A. hastata & 100 \\
A. inflata & 50 \\
A. nummularia & $100-200$ \\
A.plycarpa & 233 \\
A. vesicaria & 20 \\
Avicennia marina & 340 \\
Aster tripolium & $136-170$ \\
Mesembryanthemum crystallinum & $100-200$ \\
Sacrcobatus vermiculatus & 50 \\
Puccinellia nuttalliana & 128 \\
Distichlis spicata & 170 \\
Diplanthera wrightii & $\approx 680$ \\
Ruppia maritima & $\approx 60$ \\
Potamogeton pectiratus & $\approx 119$ \\
P.perfoliatus & $\approx 71$ \\
\hline & \\
&
\end{tabular}




\subsubsection{Avoidance of Salts}

Salt avoidance commences with root selectivity through reduced passive membrane permeability and/or improved carrier specificity for transport of ions out of the root across the endodermis (Yeo 1983). If ions (usually $\mathrm{Na}^{+}$) do reach the xylem, they eventually find their way to stem and leaf veins.

Albert (1975) points out that salt avoidance may also take the form of dilution, deposition, or extrusion of salts. For example, some grasses combine salt extrusion across root membranes with increased tissue water content, which helps dilute the salts which do accumulate. An alternative mechanism, used by many annual and perennial succulent halophytes, is to combine high water content in plant tissues with the shedding of lower, salt-saturated leaves. However, some species which renew their leaves continuously throughout the growing season (e.g. Triglochin maritima and Plantago maritima) are characterized by only small changes in water content. Presumably the shedding of old leaves is an important salt regulation mechanism in these species (Albert 1975).

\subsubsection{Accumulation and Compartmentalization of Salts}

Accumulation and compartmentalization of salts appears to be an important mechanism for species growing in areas where soil salinity is highly variable. Glenn (1987) studied the effect of salinity on ion accumulation in fourteen species from the nine genera Sporobolus, Acluropus, Leptochloa, Paspalum, Puccinnellia, Hordeum, Elymus, Distichlis and Spartina. With the exception of Distichlis palmeri, all showed the greatest intrinsic growth rate in the non-saline treatment. Sodium $\left(\mathrm{Na}^{+}\right)$and potassium $\left(\mathrm{K}^{+}\right)$ions could account for $75 \%$ of the osmotic potential at all salinities, indicating that organic solutes were not important in osmotic adjustment. Grasses co-ordinated $\mathrm{Na}^{+}$uptake and water loss to 
maintain an equilibrium of osmotic potential between shoot tissues and the external solution.

Glenn \& O'Leary (1984) found that water content and cation accumulation in euhalophytes (species showing optimal growth with some salts) maintained a constant osmotic potential gradient from shoot tissues to the external solution. Furthermore, euhalophytes accumulated more mineral cations than miohalophytes (species occurring in saline soils but showing optimal growth without additional salt). No correlation was found between mineral content and degree of salt tolerance. All species increased their water content when watered with solutions up to $180 \mathrm{mM} / \mathrm{L} \mathrm{NaCl}$. However, when watered with solutions between 180 and $720 \mathrm{~mol} / \mathrm{m}^{3} \mathrm{NaCl}$ tissue water content decreased or remained stable. The only exception was Salicornia torreyana in which water content continued to increase. Since species with the highest mineral content also had the highest water content, the authors concluded that euhalophytes were able to maintain a constant osmotic potential between shoot tissues and the external solution by accumslating ions. This conclusion is supported by Riehl \& Ungar $(1982,1983)$ who found that shoot water potentials of Salicornia europaea and Atriplex triangularis varied in direct proportion to soil water potentials, and were usually more negative.

Breins \& Larher (1982) classified sixteen coastal marsh species into three groups on the basis of tissue water and inorganic ion content. The first group included species which accumulate less than $20 \%$ inorganic ions on a dry weight basis, and in which tissue water content remains low through the growing season. These species showed the lowest salt tolerance. A second group contained species which accumulated high levels of inorganic ions in their shoots ( 20 to $35 \%$ of the dry weight) and had high levels of tissue water (450$800 \%$ of the dry weight). Species in this group, which include Triglochin maritima, Plantago maritima, Atriplex hastata, and Aster tripolium, tolerated moderate to relatively high salt levels. The third group, which included the genera Salicornia and Suaeda, had a 
large capacity to store inorganic ions (50\% of the dry weight) and water (1000\% of dry weight). These were the most salt-tolerant species.

Species which accumulate salts must have mechanisms which prevent salts from disrupting metabolic processes, since most halophyte enzymes are as sensitive to salts as those of glycophytes (e.g. Flowers, Troke \& Yeo 1977; Jefferies 1981). Whereas many glycophytes merely redistribute $\mathrm{Na}^{+}$as the plant grows, halophytes are able to store $\mathrm{Na}^{+}$in older leaves and stems in an immobile form; halophytic species appear to be able to compartmentalize salts away from the meristems and cytoplasm of the plant. Halophytes also have the ability to transport ions in the plant at rates up to ten times faster than the rate in glycophytes (Yeo 1983). This ability may enable halophytes, especially those found in areas subject to large and rapid salinity changes, to cope with changing soil salinity levels.

\subsubsection{Accumulation of Organic Solutes}

High levels of organic solutes are often found in halophytes, especially when grown under high salinity regimes (Jefferies 1980). Because such solutes are normally uncommon in plants, it is thought that they are important in osmotic adjustment. The most common solutes are amino acids (specifically proline), some polyols, methylated quaternery ammonium compounds (e.g. glycinebetaine), and several carbohydrates (Table 1.4). Amino acids are more common, and are thought to be more effective as osmotica (organic solutes used to adjust for osmotic difference between the cell and intercellular spaces) than are sugars and carbohydrates (Jefferies 1980). For example, Salicornia europaea does not accumulate mono or disaccharides, but uses highly soluble nitrogenous compounds as osmotica. It is thought that large amounts of sugar would be required to raise osmotic potentials, and that high concentrations of sugars may decrease the rate of enzyme activity in plants. Salts probably accumulate in cell vacuoles since enzyme systems 
in halophytes are salt sensitive, whereas organic solutes accumulate in the cytoplasm with the result that the osmotic potential across the tonoplast is minimized.

Stewart \& Lee (1974) studied ten halophytic species and found that, excepting Plantago maritima, proline content was over $30 \%$ of the total amino acid pool (Table 1.5) This percentage is markedly higher than that found in glycophytes. Some species, such as Triglochin maritima, Ruppia maritima and Armeria maritima, accumulated proline only when grown under saline conditions. Proline appeared to have no inhibitory effect on enzyme action, whereas $\mathrm{NaCl}$ had a marked effect, even in halophytes. This led the authors to suggest that proline was used as an osmoticum.

Cavalieri \& Huang (1979) studied Limonium carloinianum, Juncus roemerianus, Spartina alterniflora, Spartina patens, Distichlis spicata, Salicornia virginica, Salicornia bigelovii and Borrichia frutescens. Above a certain (species-specific) salinity threshold all eight species accumulated proline. Water stress from polyethylene glycol (a biologically inert carbohydrate) also induced proline accumulation. Proline accumulation occurred in $L$. carloinianum and Juncus roemerianus at $0.25 \mathrm{M} \mathrm{NaCl}$. In the succulent halophytes $S$. bigelovii, S. virginica and $B$. frutescens proline did not accumulate until the watering solution reached $0.7 \mathrm{M} \mathrm{NaCl}$, at which time the leaves showed signs of chlorosis. The authors concluded that proline accumulation was an important mechanism of salinity tolerance in L. carloinianum and J. roemerianus, but that it was not in S. bigelovii, $S$. virginica and $B$. frutescens .

Bar-Nun \& Poljakoff-Mayber (1977) examined the effect of proline accumulation in the glycophyte Pisum sativum and the halophytic shrub Tamarix tetragyna. Increases in salinity induced an increase of free proline in both species. Externally supplied proline was absorbed by the pea roots more effectively than by $T$. tetragyna, but $T$. tetragyna was more efficient at producing proline under natural conditions. The authors concluded that proline was probably an important cytoplasmic osmoticum in T. tetragyna, but that it must have other uses in the plant as well. 
Table 1.4. Occurrence of suspected osmotica in coastal halophytes (after Jefferies 1980).

Methlyated quaternary ammonium:

Atriplex hastata

Atriplex patula

Beta maritima

Halimione portulacoides

Salicornia europaea

Suaeda maritima

Proline:

Cochlearia officinalis

Glaux maritima

Juncus maritimus

Puccinellia distans

Puccinellia maritima

Spergularia marina

Spergularia media

Triglochin maritima

Proline and methylated quaternary ammonium:

Agrostis stolonifera

Armeria maritima

Aster tripolium

Festuca rubra

Limonium vulgare

Spartina anglica

Proline and miscellaneous solute:

Distichlis spicata

Juncus roemerianus

Limonium carolinianum

Spartina alterniflora

Spartina patens

Sorbitol:

Plantago maritima 
Table 1.5 Proline Contents of Halophytes (after Stewart \& Lee 1974).

\begin{tabular}{lc}
\hline \hline Species & $\begin{array}{c}\text { Proline as \% } \\
\text { of the amino acid pool }\end{array}$ \\
\hline & \\
Aster tripolium & 71 \\
Glaux maritima & 52 \\
Halimione portulacoides & 31 \\
Limonium vulgare & 35 \\
Plantago maritima & 3 \\
Puccinellia maritima & 71 \\
Salicornia europaea & 38 \\
Spartina anglica & 45 \\
Spergularia marina & 49 \\
Suaeda maritima & 58 \\
Triglochin maritima & 73 \\
\hline
\end{tabular}


Jefferies (1980) noted that of the methylated quaternary ammonium compounds, glycinebetaine appeared to be the most widespread, although other betaines do occur. Glycinebetaine is produced at particularly high levels in the Gramineae and Chenopodiaceae. Jefferies, Rudmik \& Dillon (1979) showed that quaternary ammonium compound concentration rose in the shoots of Limonium vulgare when treated with increasing levels of salts or polyethylene glycol.

In a study of ion and organic solute accumulation, Ahmad, Larher \& Stewart (1979) found that Plantago maritima maintained a relatively high water content when grown with high levels of $\mathrm{NaCl}(400 \mathrm{mM} \mathrm{NaCl})$ possibly diluting the salt in the tissues. Salinity stress also caused it to accumulates sorbitol. Jefferies, Rudmik \& Dillon (1979) found that sorbitol concentrations in P. maritima increased in both the roots and shoots when grown under saline conditions and in the presence of polyethylene glycol. The concentration of sorbitol was directly related to decreases in tissue water.

Briens \& Larher (1982) indicate that a number of other organic compounds may reach high levels in species grown under saline conditions. Sucrose accumulates in the Juncus maritima, Phragmites communis and Scirpus maritimus. Maltose is found in Atriplex hastata, and rhamnose in Plantago maritima roots. Polyols have been found in Aster tripolium, J. maritima, P. maritima and P. communis. However, Flowers, Troke \& Yeo (1977) state that the role of carbohydrates is unclear, and question their investment in osmoregulation in higher plants.

The production of organic solutes for osmoregulation may only be important in areas where soil salinity levels are constant or where salinity changes only slightly over the growing season. If rapid changes in salinity occur, production rates of organic solutes may be inadequate for them to be effective as osmotica (Jefferies, Rudmik \& Dillion 1979). The ability to accumulate ions may therefore be more important in osmotic regulation for plants growing in areas of variable salinity. 
In conclusion, halophytes utilize a variety of methods and mechanisms to tolerate saline soil conditions. No single mechanism appears to operate for all species in all situations. Instead, a complex system of salinity tolerance mechanisms have evolved which allow halophytes to grow and reproduce under conditions which would kill or severely retard the growth of other species. 


\section{Chapter 2}

\section{Study area, Survey Design and Data Analysis.}

\subsection{Saline Areas of Manitoba}

Three different types of saline ecosystem occur in Manitoba. Northern subarctic salt marshes are found along the coast of Hudson Bay. In the south-western portion of the province, salt pans or playas typical of dry continental regions of North America occur. The third type consists of sodium chloride seeps and springs. Which occur near the west shore of Lake Winnipegosis and the north-western shore of Lake Manitoba, and are the focus of this study.

\subsubsection{Hudson Bay Coastline}

A number of studies have indicated that soil salinity plays an important role in determining vegetation patterns in the saline marshes along the coast of Hudson Bay (e.g. Kershaw 1975; Ewing \& Kershaw 1986; Glooschenko \& Martini 1987). Studies of salt marshes at La Perouse Bay, Manitoba have indicated that grazing by snow geese is also important in determining vegetation composition and structure (Jefferies, Jensen \& Abraham 1979; Cargill \& Jefferies 1984). The species characteristic of these marshes are generally not found in the south.

\subsubsection{Salt Pans and Flats in South-Western Manitoba}

These generally form in areas where evaporation exceeds precipitation, and are characteristic of the semiarid and subhumid regions of the Canadian prairie provinces and 
adjacent United States. They are more common in areas with internal drainage basins. Spring meltwater accumulates in poorly drained depressions and later evaporates, concentrating salts at the soil surface. In Manitoba, salt pans are most frequently found in the dryer south-west. They are more common in southern Saskatchewan and Alberta (Dodd \& Coupland 1966; Hammer 1978). Salts are generally sodium and magnesium sulphates, though the ionic composition varies widely (Waite 1986).

\subsubsection{Sodium Chloride Seeps and Springs of the Winnipegosis and Dawson Bay Formations}

The Manitoba lowland, which includes Lakes Winnipegosis and Manitoba, is the drainage basin for Manitoba's western uplands and is the main discharge area for formation waters from the western Canadian sedimentary basin. Saline groundwater percolation from the Winnipegosis and Dawson Bay formations created a series of salt seeps and springs occur along the west shore of Lake Winnipegosis. Most of these salts are probably derived from the Prairie Evaporite formation, which was laid down during the middle Devonian and covers an extensive area beneath the Canadian prairies (Pearson 1963, Fig. 2.1). Some of the salts in the springs around Lake Winnipegosis may also come from Sulurian and Ordovician formations underlying the Winnipegosis formation (van Everdingen 1971).

Many of the springs are closely associated with reefs in the Winnipegosis formation, and the folding and faulting of rock overlying these reefs has created favorable conditions for groundwater discharge. Chemical analyses of the water from 24 springs in the Lake Winnipegosis area have indicated that sodium and chloride are the dominant ion, though others are found in smaller amounts (see van Everdingen 1971). Sodium and chloride ions are also the dominate in the soils of saline flats in the area, although sulfate, carbonate, calcium and magnesium ions also occur (Eilers1986). 


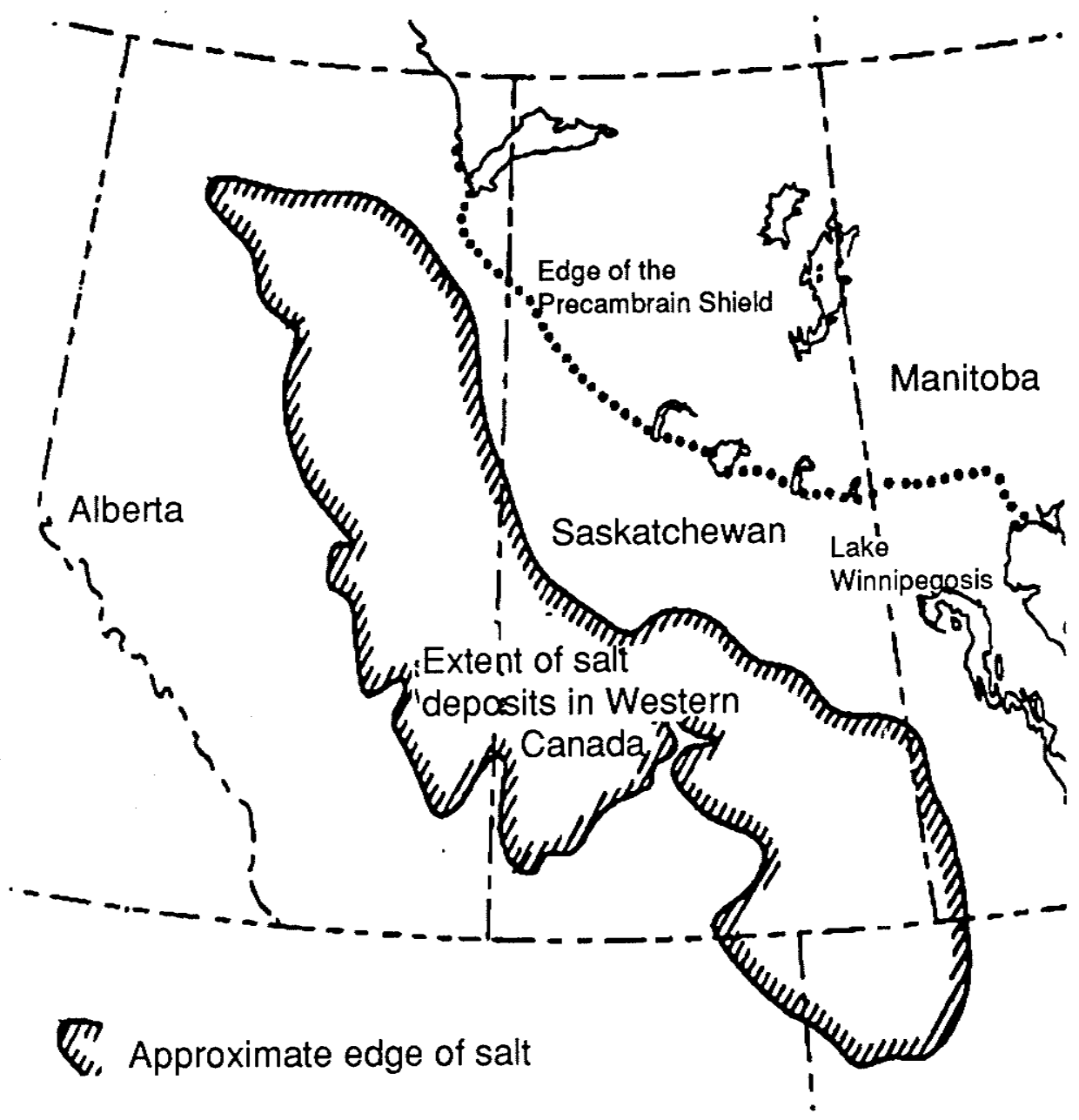

Figure 2.1 Approximate extent of salt deposits in western Canada (from Pearson 1963). 


\subsection{Study Area}

\subsubsection{Site Description}

Many of the saline flats in the Lake Winnipegosis region are disturbed, particularly in the more populated southern areas. Most of this disturbance is the results from cattle grazing on marginal farmland or the haying of saline meadows. However, a series of readily accessible saline flats located approximately $15 \mathrm{~km}$ south of Overflowing River, Manitoba were found virtually undisturbed (Figure 2.1) This area was therefore chosen for further study.

The flats were located between Highway No. 10 and the shore of Dawson Bay, Lake Winnipegosis at approximately $53^{\circ} 05^{\prime} \mathrm{N}$ and $101^{\circ} 07^{\prime} \mathrm{W}$ (Fig. 2.3). Soil salinity in the area result from extensive seeps of saline groundwater. Although no individual springs were found in the areas studied, springs did occur at several nearby locations. Soils in the saline flats were a heavy, dense silt, with occasional intervening gravel ridges. There was extensive logging in the area, but the salt flats and neighboring spruce stands were left untouched. The highway, completed in 1939 and rebuilt in 1960, appears to have had little influence on the structure and physiognomy of the flats. Aerial photographs from 1929, 1945,1981 and 1986 indicate that the overall shape of the flats and possibly the plant associations have changed little over a 60 -year period.

One of the large salt flats in the sampling area occured along the lake shore. However, daily water level records from Dawson Bay, Manitoba indicate that the water level had been high enough to cover the lowest reaches of the flat on only 19 days since 1970 , eighteen of which were in 1974. Three years of observation at the site indicated that wrack from storms does occasionally occur on the lower, muddy portions of the flat next to the lake, but it never reached the vegetated portions of the flats. 
Figure 2.2 Overview of Site I 







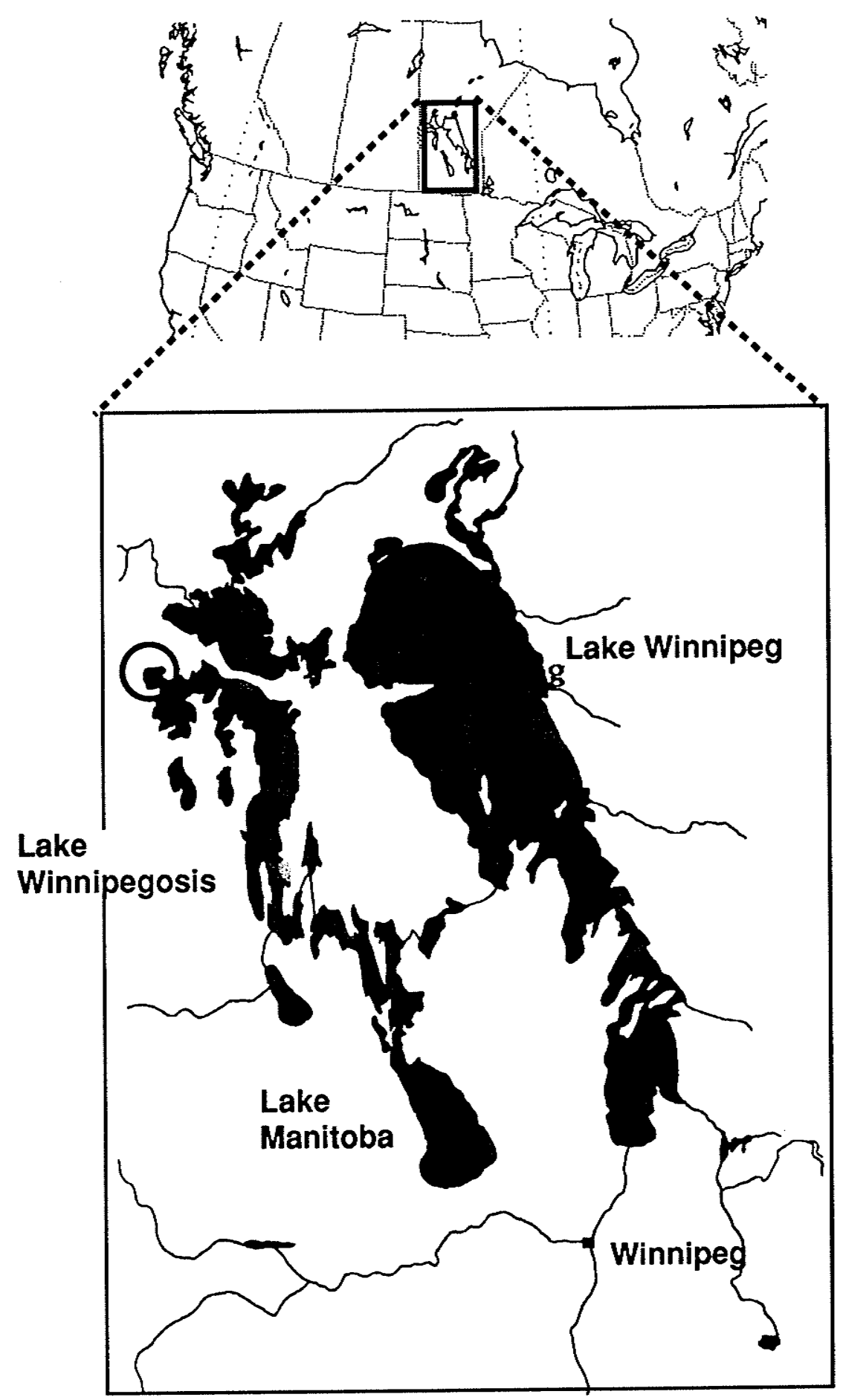

Figure 2.3. Lakes Winnipeg, Manitoba and Winnipegosis. Circle indicates approximate location of study site. 


\subsubsection{Climate}

The climate of west-central Manitoba is continental. Mean annual precipitation at The Pas, Manitoba (100 km north of the study site) is about $50 \mathrm{~cm}$, with $17 \mathrm{~cm}$ falling as snow and $33 \mathrm{~cm}$ as rain. Approximately $61 \%$ of total annual precipitation occurs from May to September. The mean annual temperature is $-0.3^{\circ} \mathrm{C}$, and ranges from a mean January low of $-22.7^{\circ} \mathrm{C}$ to a high of $18.0^{\circ} \mathrm{C}$ in July. The Pas receives an average of 2167.5 hours of bright sunshine per year (Campbell-Stokes recorder), 59\% of which occurs between May and September (all means are computed for the years 1951-1980, Environment Canada 1982).

\subsubsection{Vegetation and Physiognomy}

The study area lies within the Boreal fore:t of the Manitoba lowlands (Rowe 1972) and the Subhumid Mid-Boreal (MBs) ecoclimatic region (Ecoclimatic Working Group, 1989). The region lies south of a large terminal morain separating the Saskatchewan River and Lake Winnipegosis watersheds and is characterized by a very flat relief and poor drainage. Extensive black spruce (Picea mariana) bogs and tamarack (Larix laricina) fens have developed on the mesisol soils of these poorly-drained areas. Upland sites consisting of moderately calcareous glacial till or alluvial deposits are generally dominated by white spruce (Picea glauca) and trembling aspen (Populus tremuloides).

Extensive freshwater marshlands occur along the shore of Dawson Bay. Phragmites australis dominates most of the marshes, forming reedbeds that extend a considerable distance into the shallow waters of the lake. Saline springs and seeps which bring salt water to the surface occur locally near the lake shore. A vegetation dominated by halophytic species has developed in these areas. The combination of saline groundwater input and 
summer evaporation from the soil surface maintains high salinity levels. It should be noted that most saline areas were surrounded by stands of Picea glauca.

\subsection{Vegetation survey}

A survey of the vegetation around two large salt flats and a smaller saline meadow was conducted (Fig 2.4). All three sites were located between Highway 10 and the shore of Lake Winnipegosis. Site I, the largest of the two salt flats, was approximately $800 \mathrm{~m}$ long and $400 \mathrm{~m}$ wide and was adjacent to the lake. The other salt flat (site II) was separated from site I by a gravelly ridge dominated by $P$. glauca. This salt flat was approximately $200 \mathrm{~m}$ long and $100 \mathrm{~m}$ wide. The saline meadow, site III, was located just north of the other two sites. It was approximately $200 \mathrm{~m}$ long and $50 \mathrm{~m}$ wide.

An inventory of all of plant species occurring in and around the saline sites was taken during May and June 1987, and again in the summer of 1988. In total 79 vascular plant species were identified, and voucher specimens were deposited in the University of Manitoba herbarium (WIN). Forty-nine additional species were recorded from the forests adjacent to the salt flats. A complete species list is given in Appendix C.

Baselines for sampling transects were located parallel to the vegetation front in each of the two salt flats. Baseline 1 was located on the north side of site I, baseline 2 along its west side, and baseline 3 on the south side. Baseline 4 was located across the longest length of site II. A fifth baseline was positioned through the middle of the saline meadow at site III (Fig. 2.3). Each baseline was divided into $10 \mathrm{~m}$ segments, and a transect located at random within each segment. Each transect was perpendicular to its baseline and extended into the vegetation to the nearest height in land (usually the middle of a rosedominated gravel ridge). A total of 54 transects, ranging in length from 20 to $110 \mathrm{~m}$, were positioned in this way. During June 1987 elevations above sea level were measured at two 


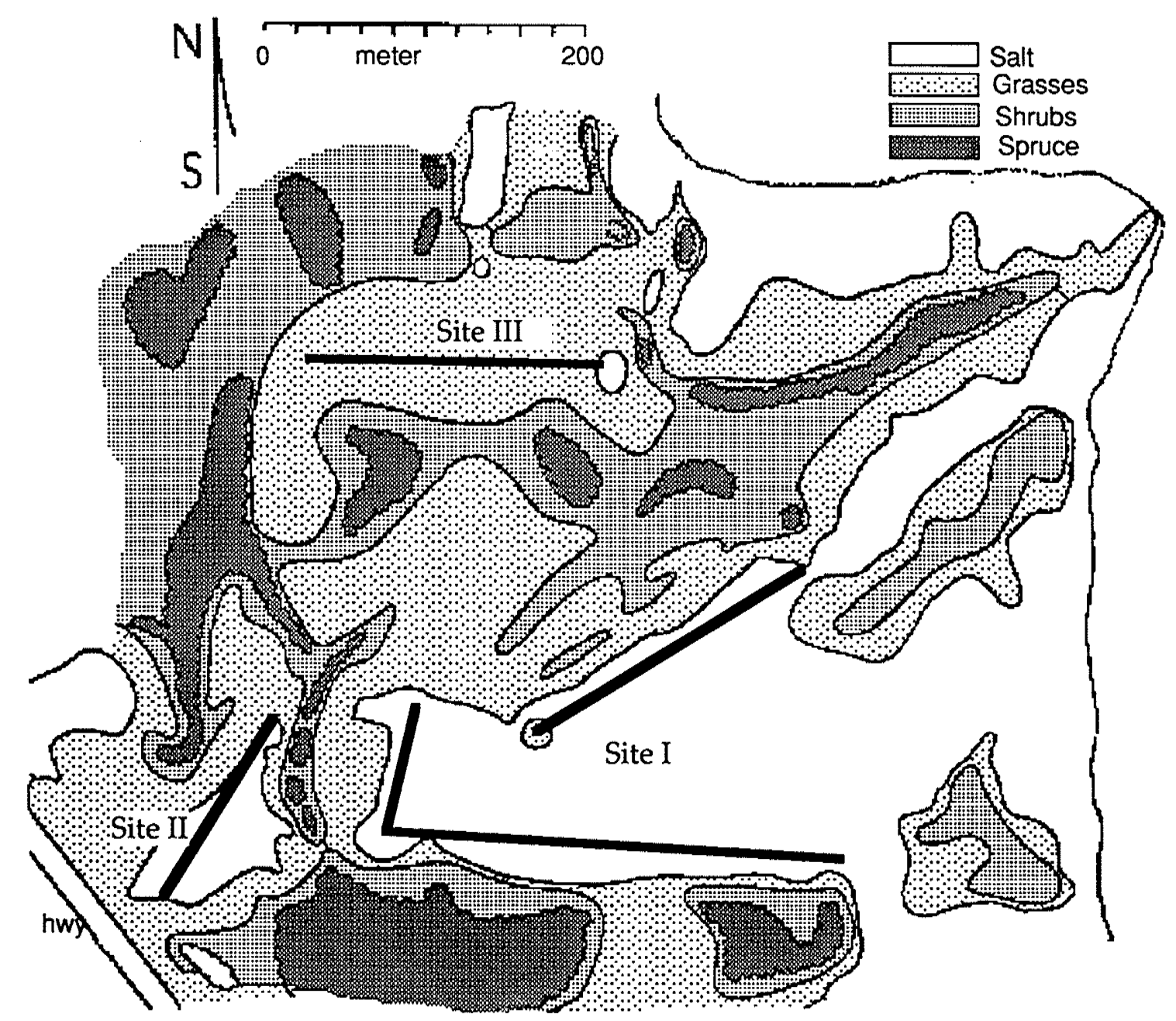

Figure 2.4 Enlarged view of the study area with the baseline trasects marked. 
meter intervals along each transect using a surveyor's level and rod. Readings were first converted to elevation above the lake level as measured on June 8,1987 . However, because the study area slopes gently toward the lake, the highest elevations of some transects were actually lower than the starting elevation of others. Elevation measurements were therefore relativized to elevations above the muddy unvegetated portion of each salt flat.

The vegetation was sampled from August 9 to 21,1987 using $0.5 \times 0.5$ m quadrats located at $2 \mathrm{~m}$ intervals along each transect. A total of 1176 quadrats were sampled. In each quadrat, percent cover of species was estimated in 5\% increments. In vegetation with little vertical structure, percent cover estimates yield reasonably consistent values that are highly correlated with aboveground biomass (Hermy 1988). For a given investigation, the size and shape of the quadrat should be determined by considerations of vegetation physiognomy and the objectives of the study (Kenkel, Juhasz-Nagy \& Podani 1989). Since the objectives of this study were to describe the vegetation and examine vegetationenvironment relationships, a small isodiametric quadrat was considered appropriate.

\subsection{Soil Sample Collection and Analysis}

A soil sample was taken in every second quadrat for a total of 686 soil samples. Samples were taken with a soil corer $6 \mathrm{~cm}$ in diameter and $10 \mathrm{~cm}$ deep. Each core was airdried in the field and later taken to the University of Manitoba where it was stored in a cold room at $4^{\circ} \mathrm{C}$. In the fall of 1987 they were further dried at $80^{\circ} \mathrm{C}$. Each dry sample was ground with a mortar and pestle and passed through a $1.7 \mathrm{~mm}$ sieve to remove gravel.

Soil bulk density was determined by weighing each dried samples before sieving, and then dividing soil mass by the volume of soil collected. Density was measured for 480 of the cores. Soil $\mathrm{pH}$ and conductivity $(\mathrm{vS})$ were measured using a 1:5 (w/v) soil to water suspension (Agarwal, Das, \& Mehrotra 1961). Because of the highly absorbant nature of 
the soil, a lower ratio of soil to water could not be used. Ten grams of dry soil and fifty grams of water were mixed for one hour in $125 \mathrm{ml}$ Erlenmeyer flasks using a mechanical shaker. The $\mathrm{pH}$ and conductivity of the slurry were measured immediately after mixing.

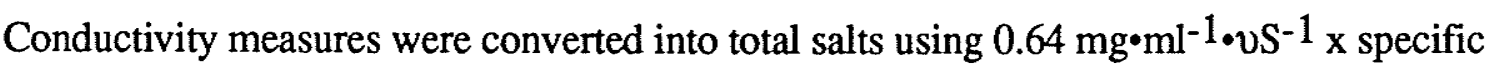
conductivity in vS as a conversion factor (Chang, Sommerfeldt, Carefoot $\&$ Schaalje 1983). This constant was verified in the lab by evaporation of extract samples $\left(\mathrm{r}^{2}=0.99\right)$. Organic matter was determined by ashing approximately $10 \mathrm{~g}$ of soil at $430^{\circ} \mathrm{C}$ for 18 hours, and was expressed as a percentage of the initial dry mass of the soil. Davies (1974) found, for soils fired at $430^{\circ} \mathrm{C}$, that the presence of $\mathrm{CaCO}_{3}$ did not affect the magnitude of the ignition-loss and provided a reliable estimation of soil organic matter.

Nitrogen, phosphate, potassium and sulfate levels were determined for 149 of the soil samples at the Manitoba Soil Testing Laboratory. To determine the levels of extractable nitrate-nitrogen and available phosphorus, 2.5 grams of soil, $1.0 \mathrm{gm}$ activated charcoal and $50 \mathrm{ml} 0.5 \mathrm{M} \mathrm{NaHCO}_{3}(\mathrm{pH} 8.5)$ in a $125 \mathrm{ml}$ Erlenmeyer flask was shaken for $30 \mathrm{~min}$ on a reciprocating shaker on slow speed. The soil extract was filtered through Whatman No. 30 paper into $125 \mathrm{ml}$ beakers. A reagent blank and standard soil sample were included with each set of 48 samples. The extracts were analyzed for $\mathrm{N}$ and $\mathrm{P}$ using a Tunicon Auto Analyzer system. Available potassium was extracted using $2.5 \mathrm{gm}$ soil in $25 \mathrm{ml}$ of neutral $1 \mathrm{~N} \mathrm{NH}_{4} \mathrm{OAc}$ shaken for 30 minutes and filtered through Whatman No. 1 paper. The Potassium concentration was determined by flame photometry using lithium as an internal standard. $\mathrm{SO}_{4}$ was extracted from $25 \mathrm{gm}$ with $50 \mathrm{ml}$ dilute $\mathrm{CaCl}_{2}$ solution and filtered through Whatman No. 42 filter paper. The $\mathrm{S}_{4}$ concentration was determined colorimetrically in an Auto Analyzer II system using $\mathrm{BaCl}_{2}$ as an indicator. All of the samples were pretested with $\mathrm{BaCl}_{2}$ to determine if the Sulfate concentration was above 10 parts per million. If it was over this level then Sulphur is not a limiting element and the sample was not run through the Auto Analyzer. All of the soil samples tested had sulphur levels over 10 parts per million, which is beyond the limits of the analysis; therefore they have not been 
reported. In addition, carbonate content was assessed by placing a drop $(<1.0 \mathrm{ml})$ of $0.05 \% \mathrm{HCl}$ solution on $5 \mathrm{~g}$ of soil. Reaction was recorded on a four-point ordinal scale from low to very high.

Total salt and nutrient measurements were originally measured on a per unit mass basis. However, since extreme variability in soil bulk density occurred within the sites, values were converted to per unit volume measurements to better reflect nutrient availability and salinity conditions in the rooting zone (Mehlich 1973; Gosselink, Hatton, \& Hopkinson 1984).

\subsection{Data analysis}

Data were entered into the University of Manitoba Amdahl mainframe computer as a matrix of 1176 quadrats (rows), 49 species, and 8 environmental variables (57 columns). All of the species with a frequency of less than $0.5 \%$ were removed from the data set, leaving 37 species.

Cluster analysis (SAS Institute, 1985) was used to classify the 1176 quadrats into vegetation 'associations', and the 37 species into 'species groups'. For both cluster analyses a chord distance matrix was used as the input dissimilarity matrix in sum of squares agglomerative cluster analysis (Orlóci 1967). Dendrograms were used to represent results and in choosing cut-off levels for groups. Vegetation associations and species groups were defined by the dominant species in each group. Species groups and vegetation associations were ordered as closely as possible, without having to break or cross branches, to the order produced by a one dimensional non-metric multidimensional scaling ordination of the species and quadrats.

For each vegetation association, means and variances were calculated for the following soil variables: $\mathrm{pH}$, percentage organic matter, available potassium, total nitrogen-nitrate, available phosphate, bulk density, and total salts. Mean elevation above the salt pan (in 
meters), total number of annuals and perennials, and mean number of species per quadrat were also computed for each association. It should be noted, however, that per quadrat measures of species diversity are only meaningful at the spatial scale of the chosen quadrat size (Kenkel, Juhász-Nagy, \& Podani 1989). This can lead to erroneous interpretations when comparisons are made between communities (Juhász-Nagy \& Podani 1983). One alternative is to use jacknife or bootstrap techniques to obtain estimates of community species richness, but these have recently been shown to give biased results (Palmer 1990). We used the following approach. A computer program was written to take a random sample of size $\underline{\underline{n}}=25$ from the 'population' of quadrats from a given vegetation association. From this sample, three vegetation parameters were computed: ShannonWeaver diversity and evenness (Pielou 1977), and species richness. The procedure was repeated 1000 times, and the mean and variance computed for each parameter. This was done for each vegetation association.

Concentration analysis (Feoli \& Orlóci 1979) was used to examine relationships within and between vegetation associations and species groups. The method begins by ordering (or 'blocking') the data matrix by species group and vegetation association. The number of occurrences of species within a given group in each of the vegetation associations is then computed. The resulting $r \times c$ contingency table (where $r=$ no. of species groups, and $c=$ no. of vegetation associations) is subjected to correspondence analysis (Hill 1974) after adjusting for differences in block size. The result is a simultaneous ordination of vegetation associations and species groups through a partitioning of the total contingency chi-squared.

All of the quadrats with complete environmental information (135) were ordinated using a non-metric multidimensional ordination (NMDS) specifying a two dimensional solution. An NMDS ordination was used because of the non-linear nature of data associated with strong vegetation trends. Since the data structure was highly non linear, the input distance measure was Euclidean chord distance modified using flexible shortest path adjustment (Bradfield \& Kenkel 1987). This method attempts to find an arrangement 
of individuals in fewer dimensions than the original data such that the interspecific distances are as similar as possible to the distances calculated in the raw data set. A major advantage of the method is that it is not limited to summarizing linear variation in data (Kenkel \& Orlóci 1986). The resulting two dimensional output of the NMDS ordination configuration summarized the strongest trends in the vegetation. Principal components analysis and correspondence analysis were also used to ordinate the vegetation data but yielded uninterpretable results, presumably because of the non-linear nature of the data.

Vegetation-environment relationships were examined using a canonical correlation analysis (Gittins 1985; Kenkel \& Burchill 1990), with the two-dimensional NMDS configuration representing one variable set and the eight environmental variables (seven soil variables plus relative elevation) the other. The two canonical eigenvectors were then superimposed on the ordination configuration, and structure correlations calculated to determine which environmental variables best accounted for variability in vegetation composition (Kenkel \& Burchill 1990). Analysis of variance (ANOVA) was used to determine if there were significant differences in environmental variables among plant associations (SAS Inst. 1985 GLM procedure). The variation within each association was presented using boxplots (Emerson \& Strenio 1983). Sheffé's multiple comparison tests where used to compare the environmental variables between each of the vegetation associations (Neter \& Wasserman 1974; SAS Inst. 1985 GLM procedure). 


\section{Chapter 3 \\ Results}

\subsection{Vegetation Associations}

Cluster analysis (Fig. 3.1) led to the delineation of eight associations, seven of which were named for the dominant (highest mean percent cover) species within the group: the eighth association (Salt Pan) includes quadrats occurring at the periphery of the unvegetated salt flats. The cluster analysis cut-off level was chosen based on both dendrogram structure and ecological considerations: specifically, lower level bifurcations only distinguished 'fine-scale' variation in the major vegetation associations. Soil and other environmental factors are summarized in Table 3.1, and vegetation characteristics in Table

\section{2 .}

An interesting feature of the salt flats is the zonation of vegetation along a gradient from the unvegetated salt pan to the gravel ridges, which corresponds to an increase in relative elevation and a concomitant decrease in soil salinity. Along the gradient, sharp vegetation discontinuities or 'edges' occur where species composition changes dramatically over short distances. However, analysis of trends in soil variables and relative elevation along individual transects indicate that these vegetation edges did not occur at the same positions as discontinuities in environmental factors. One consequence of discontinuities in the vegetation is that the associations show little overlap in species composition (Fig. 3.2). The discontinuities that occur are especially sharp near the lower elevation end of the gradient, which corresponds to areas with very low species richness, low vegetation profile and high salinity. The mean number of species per quadrat, and mean total cover, increased with decreasing soil salinity (Table 3.2). There is also an increase in the proportion of annuals at higher salinities. Species richness increases with decreasing soil salinity, with the trend appearing to be linear $\left(r^{2}=0.713, \underline{P}<0.001\right.$, Fig. 3.3): a random sample of 25 
quadrats from the least saline associations (Calamagrostis, Agropyron, and Rosa) yields on average from 20 to 25 species, while a sample of the same size from the most saline associations (Salt Pan and Puccinellia) yields only 8 or 9. Shannon-Weaver diversity and evenness values generally increase with decreasing salinity. The exception is the Salt Pan association, which has the greatest evenness and relatively high Shannon-Weaver diversity. There is also an increase in the proportion of annual species at higher salinities.

The Hordeum association contains approximately $30 \%$ of the quadrats. Its large 'size', together with its distinctive flora, resulted in it being last to fuse with other groups in the dendrogram. The grasses Hordeum jubatum and Distichlis stricta codominate in this association. Grindelia squarrosa is the dominant forb. This association is found at intermediate relative elevations, and at intermediate soil salinities. In general the soil was peaty, wet and underlain by heavy clay.

The Salt Pan association, which forms a second outlying group in the dendrogram, was characterized by very low plant cover and the presence of salt-tolerant annuals. No single species dominated. Triglochin maritima and Puccinellia nuttalliana had the highest mean cover, but occurred infrequently. Species with the highest frequency were the salt-tolerant annuals Salicornia rubra and Spergularia marina. Other small, non-clonal species such as Glaux maritima and Suaeda depressa also occurred. Quadrats from this association have the highest salinities and occurred at the lowest relative elevations. These areas were very flat, and had the poorest drainage. There is very little change in soil texture or salinity through the soil profile.

The Puccinellia, Triglochin and Spartina associations form a third major group in the dendrogram. They were found at low relative elevations (though higher than the salt pan), and have intermediate to high soil salinities. 


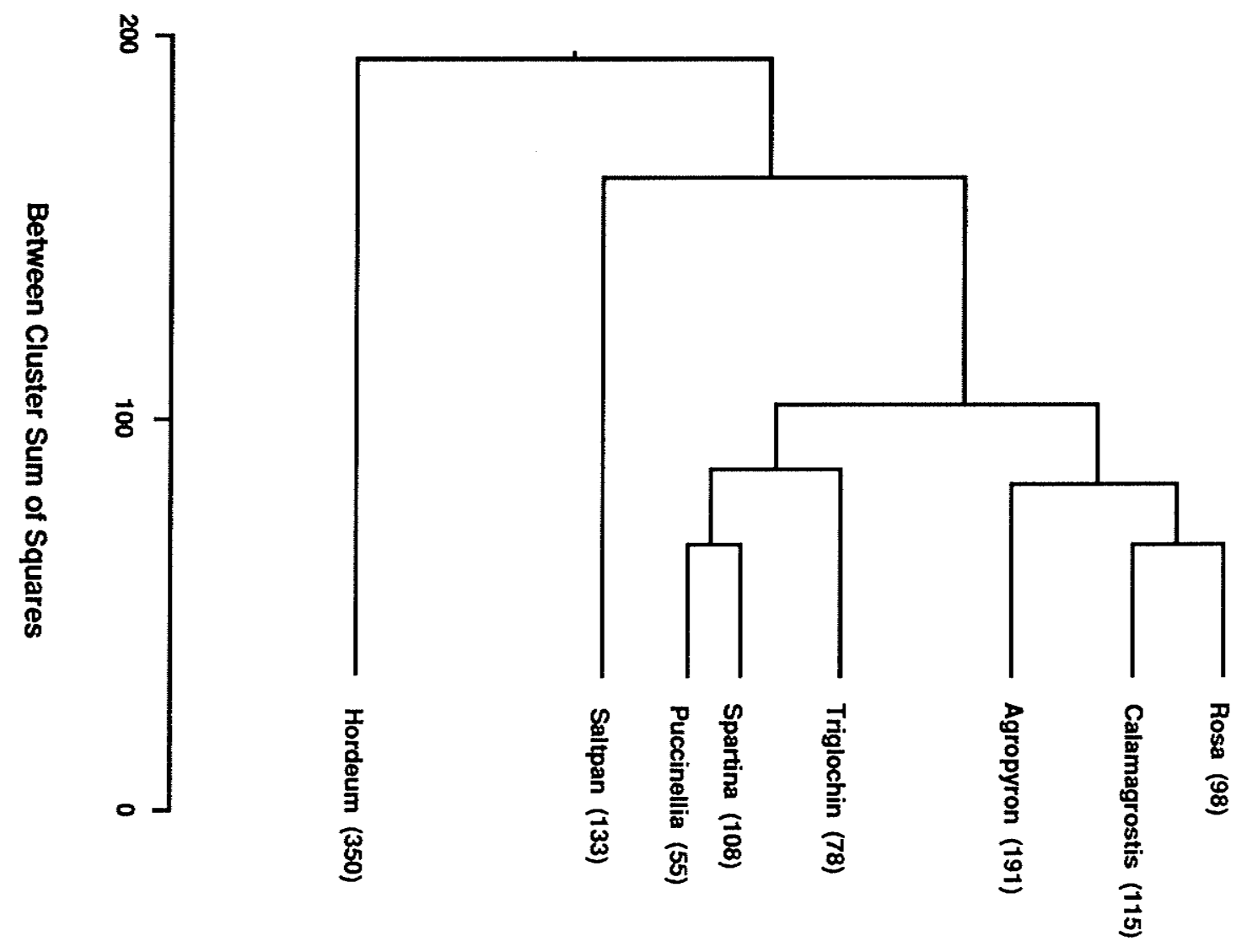

Figure. 3.1. Sum of squares agglomerative cluster analysis of the 1176 quadrats, showing the eight vegetation associations. Lower level bifurcations are not shown. Values in brackets are the number of quadrats in each association. 
Table 3.1. Soil and environmental factors (means \pm 1 s.d.) for the eight vegetation associations.

\begin{tabular}{|c|c|c|c|c|c|c|c|c|}
\hline & Salt pan & Puccinellia & Triglochin & Hordeum & Spartina & Agropyron & Calamagrostis & Rosa \\
\hline Total salts $\left(\mathrm{mg}^{\prime} \cdot \mathrm{ml}^{-1}\right)$ & $\begin{array}{l}20.1 \pm 6.0 \\
(54)^{*}\end{array}$ & $\begin{array}{l}16.4 \pm 4.9 \\
(46)\end{array}$ & $\begin{array}{l}14.8 \pm 6.1 \\
(33)\end{array}$ & $\begin{array}{l}10.2 \pm 3.6 \\
(150)\end{array}$ & $\begin{array}{l}7.9 \pm 3.7 \\
(40)\end{array}$ & $\begin{array}{l}7.1 \pm 3.2 \\
(92)\end{array}$ & $\begin{array}{l}4.7 \pm 2.3 \\
(39)\end{array}$ & $\begin{array}{l}3.9 \pm 3.1 \\
(26)\end{array}$ \\
\hline Relative Elevation (m) & $\begin{array}{l}0.05 \pm 0.04 \\
(183)\end{array}$ & $\begin{array}{l}0.15 \pm 0.05 \\
(55)\end{array}$ & $\begin{array}{l}0.14 \pm 0.07 \\
(78)\end{array}$ & $\begin{array}{l}0.19 \pm 0.15 \\
(350)\end{array}$ & $\begin{array}{l}0.18 \pm 0.11 \\
(108)\end{array}$ & $\begin{array}{l}0.32 \pm 0.21 \\
(191)\end{array}$ & $\begin{array}{l}0.27 \pm 0.15 \\
(115)\end{array}$ & $\begin{array}{l}0.45 \pm 0.23 \\
(98)\end{array}$ \\
\hline $\mathrm{pH}$ & $\begin{array}{l}8.8 \pm 0.2 \\
(92)\end{array}$ & $\begin{array}{l}8.3 \pm 0.2 \\
(48)\end{array}$ & $\begin{array}{l}8.1 \pm 0.5 \\
(47)\end{array}$ & $\begin{array}{l}7.8 \pm 0.4 \\
(213)\end{array}$ & $\begin{array}{l}8.1 \pm 0.4 \\
(52)\end{array}$ & $\begin{array}{l}7.9 \pm 0.39 \\
(118)\end{array}$ & $\begin{array}{l}7.9 \pm 0.3 \\
(57)\end{array}$ & $\begin{array}{l}7.5 \pm 0.3 \\
(59)\end{array}$ \\
\hline Potassium (ppm) & $\begin{array}{l}255 \pm 108 \\
(19)\end{array}$ & $\begin{array}{l}332 \pm 94 \\
(24)\end{array}$ & $\begin{array}{l}357 \pm 249 \\
(47)\end{array}$ & $\begin{array}{l}470 \pm 158 \\
(41)\end{array}$ & $\begin{array}{l}272 \pm 88 \\
(9)\end{array}$ & $\begin{array}{l}319 \pm 158 \\
(21)\end{array}$ & $\begin{array}{l}453 \pm 185 \\
(17)\end{array}$ & $\begin{array}{l}504 \pm 167 \\
(14)\end{array}$ \\
\hline Nitrogen (ppm) & $\begin{array}{l}1.7 \pm 1.4 \\
(19)\end{array}$ & $\begin{array}{l}7.10 \pm 4.8 \\
(24)\end{array}$ & $\begin{array}{l}0.6 \pm 0.3 \\
(47)\end{array}$ & $\begin{array}{l}5.0 \pm 5.3 \\
(41)\end{array}$ & $\begin{array}{l}3.6 \pm 2.3 \\
(9)\end{array}$ & $\begin{array}{l}6.5 \pm 5.08 \\
(21)\end{array}$ & $\begin{array}{l}3.9 \pm 3.0 \\
(17)\end{array}$ & $\begin{array}{l}9.7 \pm 14.5 \\
(14)\end{array}$ \\
\hline Phosphorus (ppm) & $\begin{array}{l}11.8 \pm 13.7 \\
(19)\end{array}$ & $\begin{array}{l}19.0 \pm 8.8 \\
(24)\end{array}$ & $\begin{array}{l}17.2 \pm 13.3 \\
(47)\end{array}$ & $\begin{array}{l}37.8 \pm 14.4 \\
(41)\end{array}$ & $\begin{array}{l}27.2 \pm 11.0 \\
\text { (9) }\end{array}$ & $\begin{array}{l}33.5 \pm 14.7 \\
(21)\end{array}$ & $\begin{array}{l}47.5 \pm 14.0 \\
(17)\end{array}$ & $\begin{array}{l}53.4 \pm 13.0 \\
(14)\end{array}$ \\
\hline Bulk Density $\left(g^{*} \cdot \mathrm{ml}^{-1}\right)$ & $\begin{array}{l}1.36 \pm 0.24 \\
(54)\end{array}$ & $\begin{array}{l}0.83 \pm 0.26 \\
(46)\end{array}$ & $\begin{array}{l}0.69 \pm 0.30 \\
(33)\end{array}$ & $\begin{array}{l}0.49 \pm 0.19 \\
(150)\end{array}$ & $\begin{array}{l}0.70 \pm 0.33 \\
(40)\end{array}$ & $\begin{array}{l}0.59 \pm 0.28 \\
(92)\end{array}$ & $\begin{array}{l}0.47 \pm 0.29 \\
(39)\end{array}$ & $\begin{array}{l}0.39 \pm 0.19 \\
(26)\end{array}$ \\
\hline Organic Matter (\%) & $\begin{array}{l}5.9 \pm 2.8 \\
(93)\end{array}$ & $\begin{array}{l}11.3 \pm 4.7 \\
(50)\end{array}$ & $\begin{array}{l}17.0 \pm 16.1 \\
(47)\end{array}$ & $\begin{array}{l}22.4 \pm 15.9 \\
(212)\end{array}$ & $\begin{array}{l}14.3 \pm 11.0 \\
(53)\end{array}$ & $\begin{array}{l}20.7 \pm 11.7 \\
(121)\end{array}$ & $\begin{array}{l}19.8 \pm 9.9 \\
(57)\end{array}$ & $\begin{array}{l}27.9 \pm 12.4 \\
(60)\end{array}$ \\
\hline Carbonates & very high & high & high & medium & medium & low & low & low \\
\hline Observed Drainage & poor & poor & poor & poor & moderate & good & moderate & very good \\
\hline
\end{tabular}

` Sample size. 
Table 3.2. Vegetation characteristics (means \pm 1 s.d.) for the eight vegetation associations.

\begin{tabular}{|c|c|c|c|c|c|c|c|c|}
\hline & Salt pan & Puccinellia & Triglochin & Hordeum & Spartina & Agropyron & Calamagrostis & Rosa \\
\hline No. of quadrats & 183 & 55 & 78 & 350 & 108 & 191 & 115 & 98 \\
\hline Mean species number ${ }^{*}$ & $2.3 \pm 1.1$ & $3.3 \pm 0.8$ & $4.0 \pm 1.3$ & $3.7 \pm 1.0$ & $4.8 \pm 1.2$ & $5.4 \pm 1.6$ & $4.8 \pm 2.0$ & $8.3 \pm 2.4$ \\
\hline Shannon-Weaver ${ }^{\dagger}$ & $1.88 \pm 0.22$ & $1.02 \pm 1.05$ & $1.56 \pm 0.09$ & $1.37 \pm 0.10$ & $1.74 \pm 0.08$ & $2.21 \pm 0.11$ & $1.89 \pm 0.11$ & $2.62 \pm 0.05$ \\
\hline Evenness ${ }^{\dagger}$ & $0.84 \pm 0.06$ & $0.49 \pm 0.02$ & $0.59 \pm 0.03$ & $0.56 \pm 0.04$ & $0.67 \pm 0.04$ & $0.71 \pm 0.03$ & $0.63 \pm 0.03$ & $0.82 \pm 0.02$ \\
\hline Species Richness $†$ & $9.48 \pm 1.73$ & $7.93 \pm 0.26$ & $13.84 \pm 0.88$ & $11.83 \pm 1.63$ & $13.98 \pm 3.30$ & $23.39 \pm 2.37$ & $20.20 \pm 1.61$ & $24.59 \pm 1.42$ \\
\hline Mean total cover ${ }^{*}$ & $15.9 \pm 20.9$ & $120.1 \pm 13.9$ & $\$ 12.2 \pm 22.0$ & $116.5 \pm 14.2$ & $134.3 \pm 22.0$ & $137.2 \pm 24.5$ & $142.7 \pm 31.2$ & $158.2 \pm 37.9$ \\
\hline Annuals & 5 & 4 & 6 & 5 & 4 & 5 & 2 & 1 \\
\hline Perennials & 9 & 4 & 9 & 15 & 19 & 29 & 22 & 27 \\
\hline
\end{tabular}

* Per quadrat.

† Mean of 1000 random samples of 25 quadrats (see text). 


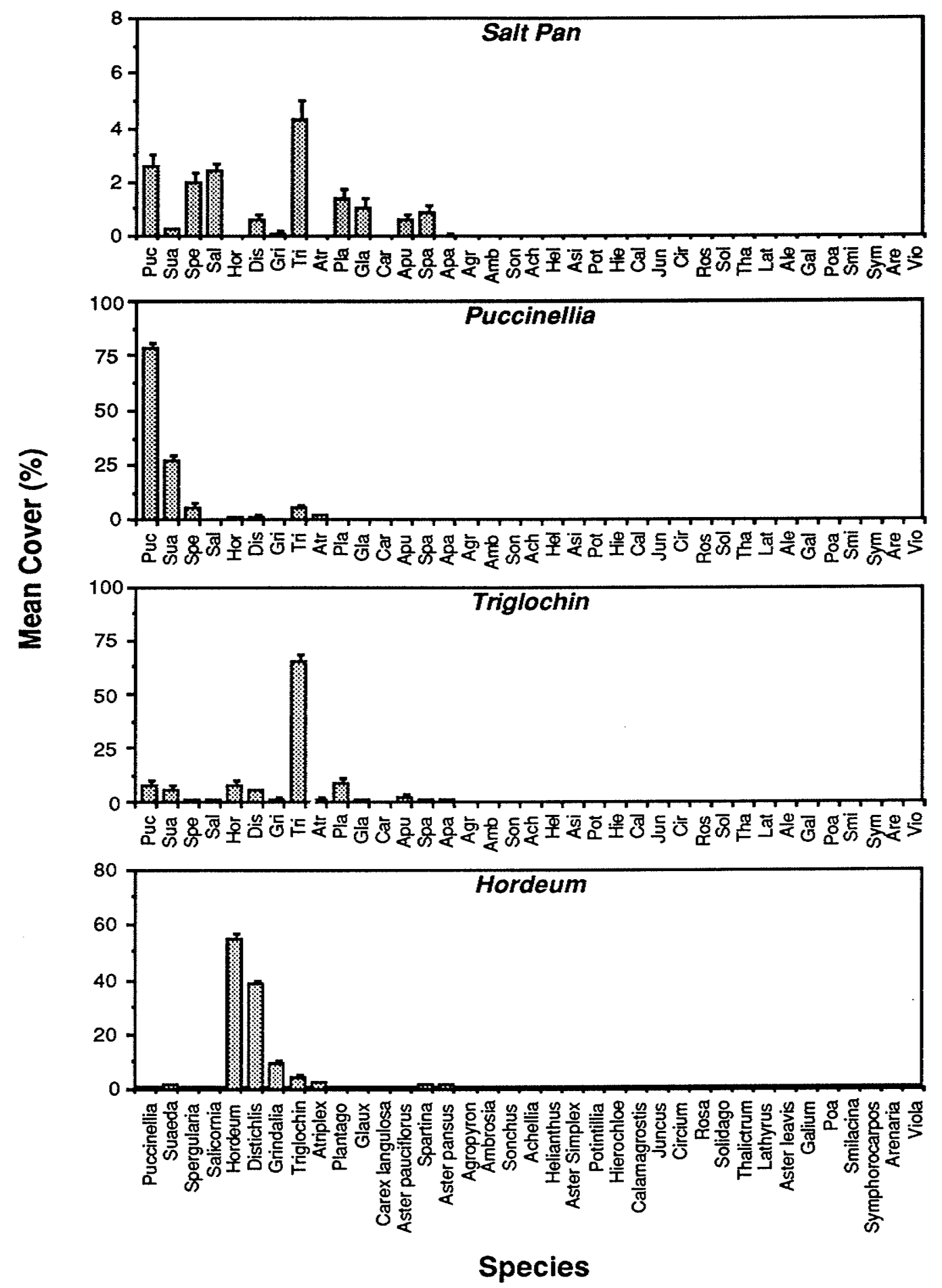

Figure. 3.2. Mean percent cover $( \pm 1$ s.e.) of species in each of the eight vegetation associations. 

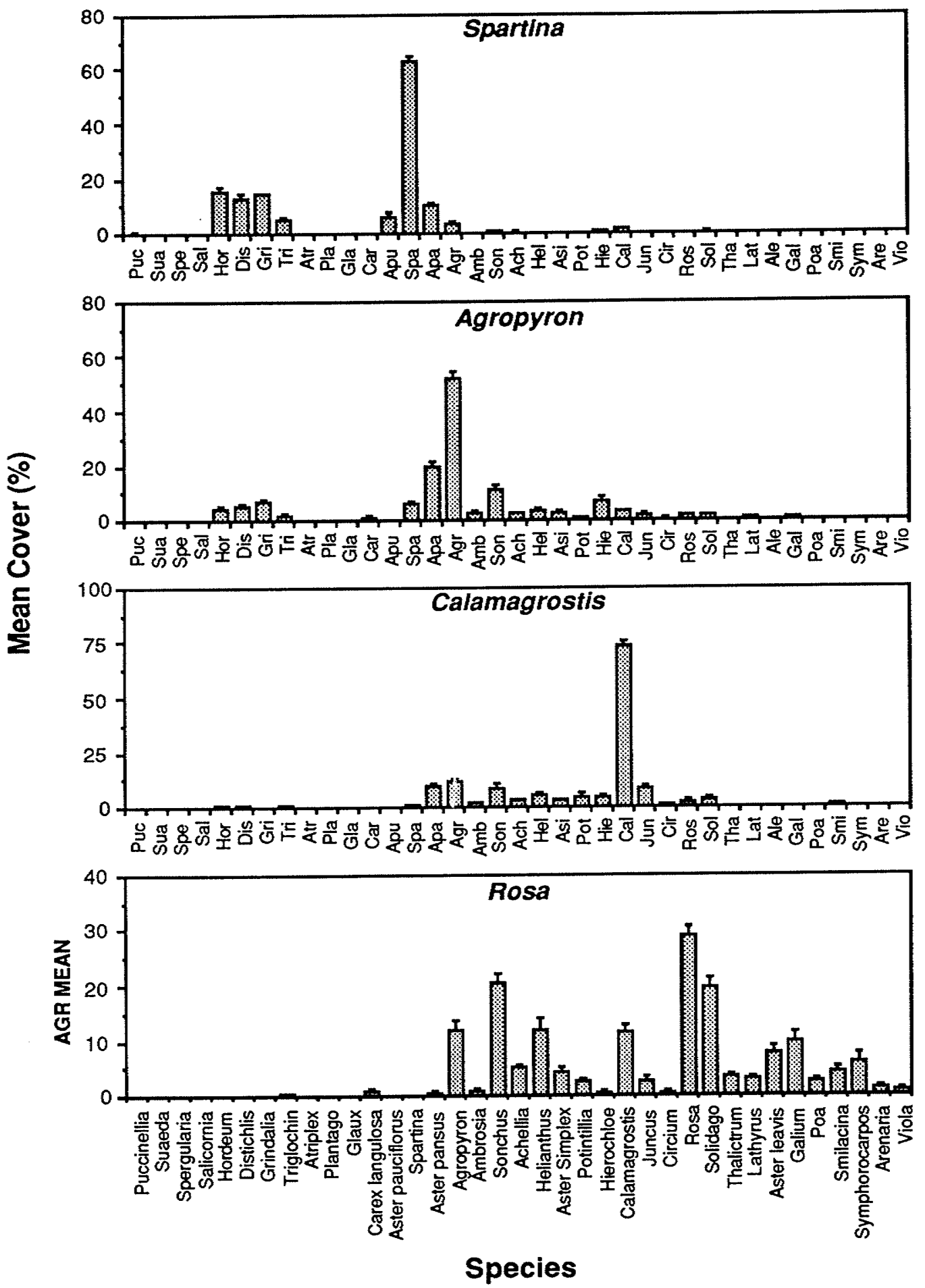

Figure. 3.2 (continued). Mean percent cover ( \pm 1 s.e.) of species in each of the eight vegetation associations. 


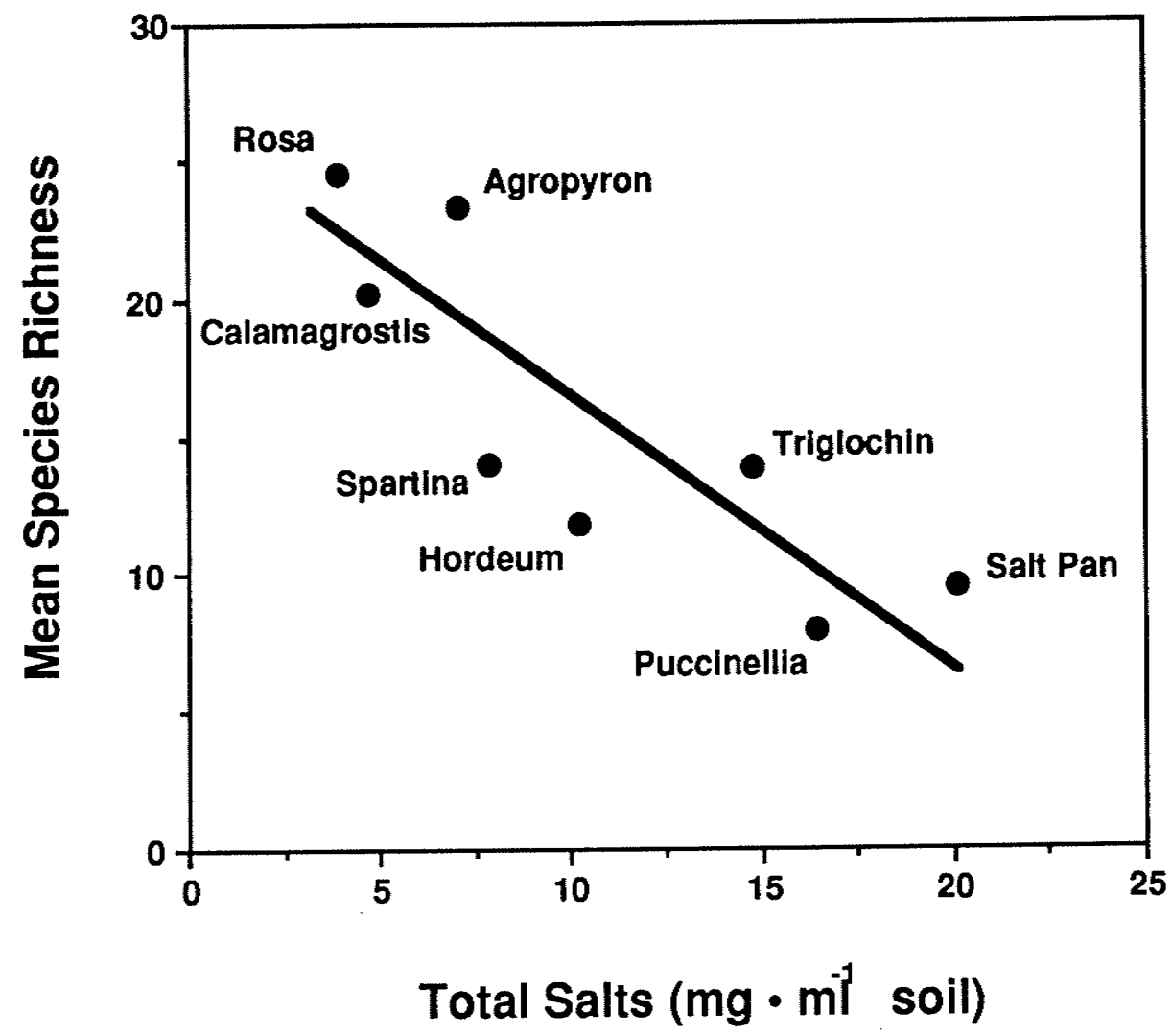

Figure. 3.3 The relationship between mean species richness and mean soil salinity for the eight vegetation associations. The fitted line was obtained using principal components analysis. 
The Puccinellia association was dominated by the perennial grass Puccinellia nuttalliana which forms a low growing mat. Suaeda depressa was also common. Soil profiles showed a thin organic layer overlying a heavy silt. This association appears only in wet areas, where there appeared to be periodic water flow. Water flow may allow a greater input of nutrients than is found in the surrounding salt flats (Table 3.1)

The Triglochin association was dominated almost completely by Triglochin maritima; it often occurred in a dwarfed form which forms a very dense sod. The species was also commonly found elsewhere in the saline community, but only as scattered much larger individuals. Although many species were found with T. maritima, they usually occurred as isolated individuals or in small gaps of the Triglochin sod. This association is common in wet areas, particularly around small salt springs or seeps.

The Spartina association was dominated by the grass Spartina gracilis. It is common next to the salt pan in areas where the Puccinellia, Triglochin, and Hordeum associations do not occur. It also formed narrow bands between the Hordeum and Agropyron associations. The soils of this association were usually better drained and had more gravel than other areas near the salt pan, and had a deeper organic layer. S. gracilis does not form a dense mat.

A fourth group in the dendrogram consisted of the Agropyron, Calamagrostis and Rosa associations. These occurred at the highest relative elevations and had the lowest soil salinities. Although the salinity levels did vary between these three associations the differences were not significant (Table 3.3). This indicates that some other soil factors may distinguish these associations. All were dominated by tall grasses or shrubs, and have a much higher species richness and diversity than other other associations (Table 3.2).

The Agropyron association was dominated by the tall grass Agropyron trachycaulum . The forbs Aster pansus, Helianthus maximilania, and Sonchus arvense were also common. This association was found at higher elevations, on well drained soils with moderately low salinity, and a deep organic layer. 
Table 3.3 Results of Scheffe's multiple comparison test. ' 1 ' indicates a significant $(\alpha=0.05$ ) difference between the two associations based on the soil parameter

Soil variables

\begin{tabular}{|c|c|c|c|c|c|c|c|c|c|}
\hline \multicolumn{2}{|c|}{ Associations } & ts & ele & $\mathrm{pH}$ & en & org & $p$ & $\mathrm{n}$ & k \\
\hline span & puc & - & - & 1 & 1 & - & - & - & - \\
\hline span & tri & 1 & - & 1 & 1 & 1 & - & - & - \\
\hline span & hor & 1 & 1 & 1 & 1 & 1 & 1 & - & - \\
\hline span & spa & 1 & 1 & 1 & 1 & - & - & - & - \\
\hline span & agr & 1 & 1 & 1 & 1 & 1 & - & - & - \\
\hline span & cal & 1 & 1 & 1 & 1 & 1 & 1 & - & - \\
\hline span & ros & 1 & 1 & 1 & 1 & 1 & 1 & 1 & - \\
\hline puc & tri & - & - & - & - & - & - & - & - \\
\hline puc & hor & 1 & - & 1 & 1 & 1 & 1 & & \\
\hline puc & spa & 1 & - & - & - & - & - & - & - \\
\hline puc & agr & 1 & 1 & 1 & 1 & 1 & - & - & - \\
\hline puc & $\mathrm{cal}$ & 1 & 1 & 1 & 1 & - & 1 & - & - \\
\hline pur; & ros & 1 & 1 & 1 & 1 & 1 & 1 & - & - \\
\hline tri & hor & 1 & - & - & 1 & - & - & - & - \\
\hline tri & spa & 1 & - & - & - & - & - & - & - \\
\hline tri & agr & 1 & 1 & - & - & - & - & - & ${ }^{-}$ \\
\hline tri & cal & 1 & 1 & - & - & - & - & - & - \\
\hline tri & ros & 1 & 1 & 1 & 1 & - & - & 1 & - \\
\hline hor & spa & - & - & 1 & 1 & 1 & - & - & - \\
\hline hor & agr & 1 & 1 & - & - & - & - & - & - \\
\hline hor & $\mathrm{cal}$ & 1 & 1 & - & - & - & - & - & - \\
\hline hor & ros & 1 & 1 & 1 & - & - & - & - & 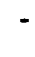 \\
\hline spa & agr & - & 1 & 1 & - & - & - & - & - \\
\hline spa & cal & - & 1 & - & - & - & - & - & - \\
\hline spa & ros & - & 1 & 1 & 1 & 1 & - & - & - \\
\hline agr & cal & - & - & - & - & - & $\cdot$ & - & - \\
\hline agr & ros & - & 1 & 1 & - & - & - & - & - \\
\hline cal & ros & $=$ & 1 & 1 & $=$ & - & $=$ & - & - \\
\hline
\end{tabular}


The Calamagrostis association was dominated by the tall perennial grass Calamagrostis inexpansa. This grass formed a loose sod and a dense standing litter that remains for about two years. Low species richness and diversity characterize this association (Table 3.2). The environmental variables were similar to those found in the Agropyron association (Tables 3.1 and 3.3).

No single species dominated the Rosa association. This was the only association in which the shrubs Rosa acicularis and Symphoricarpos alba occurred with any abundance. Other species with high cover included Sonchus arvensis, Helianthus maximilianii, Galium boreale, Aster leaves, Agropyron trachycaulum, Calamagrostis inexpansa and Solidago canadensis. This association was only found on the gravel ridges around the salt flats. The soils were well drained with low salinity, high organic content and a low $\mathrm{pH}$. The dominants were tall (1-1.5 m), with only shade tolerant species growing below them.

Although the associations have been described in the order that the divided out in the cluster analysis, it is important to point out that these associations occurred in a very specific order. The Salt pan association was always found in the most saline areas, followed in sequence of increasing salinity, by the Puccinellia, Triglochin, Hordeum, Spartina, Agropyron, Calamagrostis and finally Rosa associations. This order was always maintained in the field. Thus Spartina always occurred after Hordeum, and before Agropyron. The Agropyron association never occurred closer to the salt pan when the Hordeum association was present.

\subsection{Species Groups}

Cluster analysis of the 37 species delineated eight groups (Fig. 3.4). The first dendrogram subdivision separated species of saline habitats (the Salt Pan, Hordeum, Spartina and Triglochin species groups) from those characteristic of non-saline or slightly 
saline soils. The Salt Pan group contained the grass Puccinellia nuttalliana and three annuals which are known to be highly salt-tolerant. The Triglochin group included two small salt-tolerant species (Glaux maritima and Atriplex patula) and the short-lived perennial Plantago maritima. These species are also characteristic of saline habitats, although Triglochin maritima was occasionally found in non-saline areas. The Hordeum species group included Hordeum jubatum and Distichlis stricta, which occurred at intermediate salinities. The former is a short-lived, densely tufted species, while the latter has extensive creeping rhizomes. Associated with these was the composite Grindelia squarrosa. The final species in the first subdivision of the dendrogram were Spartina gracilis and the composite Aster pauciflorus. Both are characteristic of moderately saline soils in the Prairie provinces.

The other half of the first subdivision contains 23 species in four groups. Agropyron trachycaulum occurs in a group with the composites Aster pansus and Ambrosia psilostachya. All three tolerate low salinity levels. Calamagrostis inexpansa occurs in a large group of nine species which includes another grass (Hierochloe odorata) and five composites. These species can be found on moderate to non-saline soils across the prairies. The final two groups (Rosa and Symphoricarpos) include species characteristic of the nonsaline sites adjacent to the gravel ridges.

\subsection{Relationship Between Vegetation Associations and Species Groups}

A two-dimensional scattergram representation of the concentration analysis results is shown in Fig. 3.5. The ordination displays the characteristic 'horseshoe' shape of correspondence analysis, which strongly suggests that a single environmental gradient underlies vegetation variation (Kenkel \& Orlóci 1986; Wartenberg, Ferson \& Rohlf 1987).

The first axis appears to represent a salinity gradient, with salinity increasing from left to right. In general there is a close one-to-one correspondence between the vegetation associations and species groups, indicating the discontinuous nature of vegetational 
variation. The Puccinellia and Salt Pan associations both show strongest affinity with the species Puccinellia nuttalliana, Suaeda depressa, Spergularia marina, and Salicornia rubra. The Triglochin, Hordeum, Spartina, and Agropyron associations show strong correspondence to species groups with the same names. The Calamagrostis association shows equal affinity with Calamagrostis and Agropyron species groups. Finally, the Rosa association shows strongest affinity to the Rosa and Symphorocarpos species groups.

\subsection{Vegetation-Environment Relationships}

In the two-dimensional NMDS ordination of 135 quadrats (Fig. 3.6), the vegetation associations to which quadrats were assigned (see Fig. 3.1) are presented to aid interpretation. The two canonical correlation analysis axes are also displayed. Note that these axes, while linearly uncorrelated, are not orthogonal (see Gittins 1985, p. 150; Kenkel \& Burchill 1990). Both canonical correlations are highly significant: axis I, $R^{2}=$ $0.674, \mathrm{P}<0.001$; axis II, $\mathrm{R}^{2}=0.275, \mathrm{P}<0.001$. However, the redundancy values for canonical axes I and II (which indicate the proportion of vegetation variation accounted for by the environmental variables) were $56.5 \%$ and $4.4 \%$ respectively, indicating that the majority of trended vegetation-environment variation occurs along the first axis. Structure correlations for the eight environmental factors (seven soil variables plus relative elevation) are presented in Table 3.4. The variable 'total salts' shows the highest structure correlation with the first axis, indicating a strong trend of decreasing salinity from left to right. Soil $\mathrm{pH}$ shows a similar trend, while relative elevation increases from left to right. Soil nutrients, organic content and bulk density all show low correlations with the first and second axes. Structure correlations on the second axis are generally weak, with total salts and bulk density showing the strongest trends.

Box plots of each of environmental variables indicate decreasing trends in salinity (Figure 3.7), $\mathrm{pH}$ and density from the salt pan to the Rosa association (Appendix D). Note that the change in salinity becomes less pronounced near the Rosa association. 
Elevation increases and the other variables do not show a strong trend across the gradient (Appendix D).

Sheffé's test indicated that there was a significant difference between most of the associations based on salinity alone (Table 3.3 Sheffé's test). Other factors such as $\mathrm{pH}$, density and organic matter may separate the Salt Pan and Puccinellia, and Spartina and Hordeum associations. The Puccinellia and Triglochin associations do not differ in any of the measured environmental variables. Elevation and $\mathrm{pH}$ show significant changes between each associations with the exceptions of Calamagrostis and Agropyron. Indeed, these two associations do not show a significant difference between any of the measured environmental variables (Appendix D).

I further examined the relationship between vegetation and salinity by plotting mean percent cover of the nine most frequently occurring species against salinity (Fig. 3.8a, 3.8b). All species show a general 'bell-shaped' response to the salinity gradient. The response of Salicornia rubra is truncated at the high salinity end, indicating that it is most commonly found where salinity is highest. Puccinellia nuttalliana also occurs in highly saline areas, while Triglochin maritima is found at both intermediate to high salinities. Hordeum jubatum and Distichlis stricta both have highest cover at intermediate salinities. Spartina gracilis was most common at low to intermediate salinities, but occasionally occurred in highly saline areas. Agropyron trachycaulum, Calamagrostis inexpansa, and Rosa acicularis all have distributions which are truncated at the low salinity end of the gradient. Of the three, Agropyron trachycaulum appears to be the most salt tolerant. 


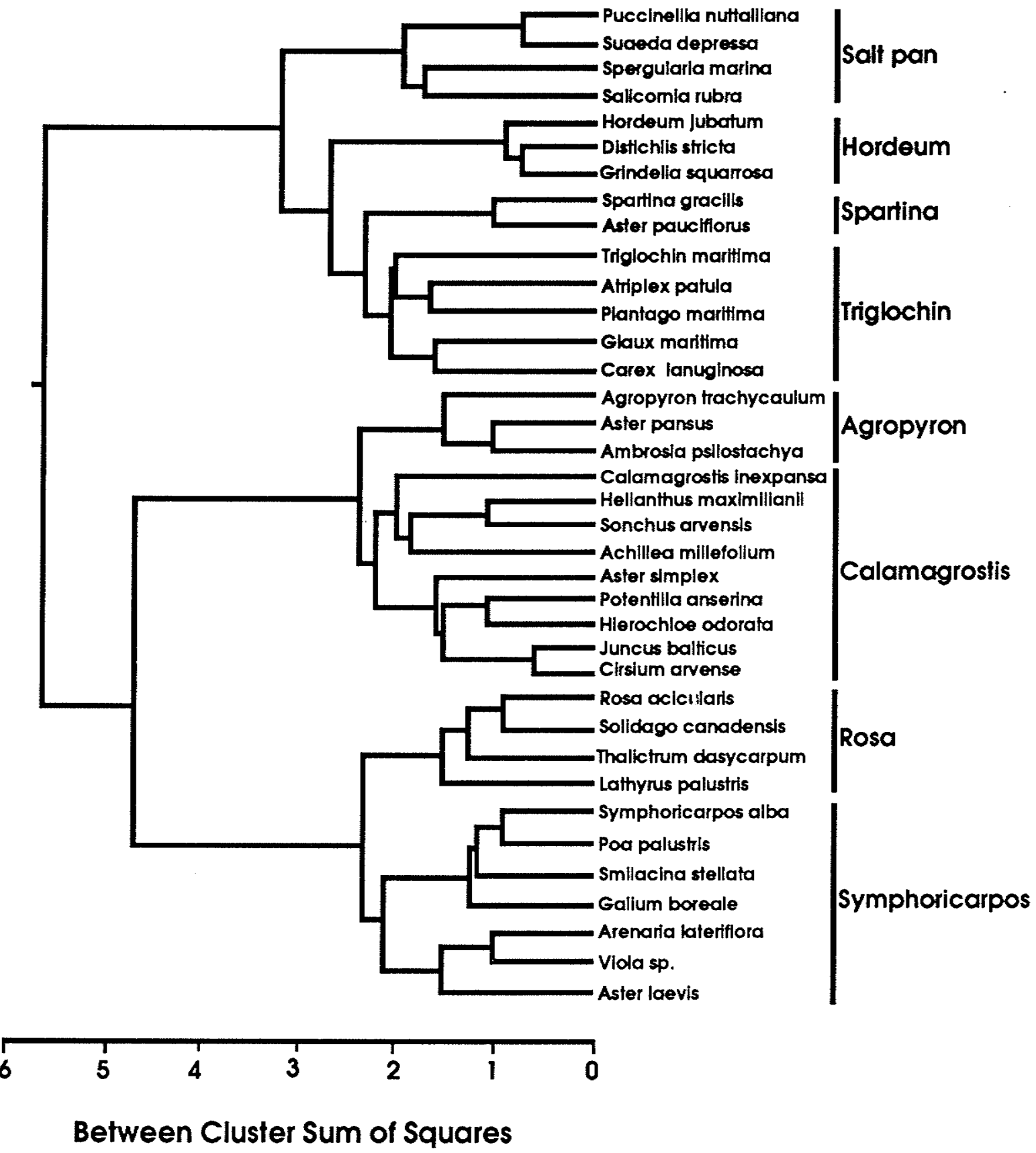

Figure 3.4 Sum of squares agglomerative cluster analysis of the 37 species, showing the eight species groups. 


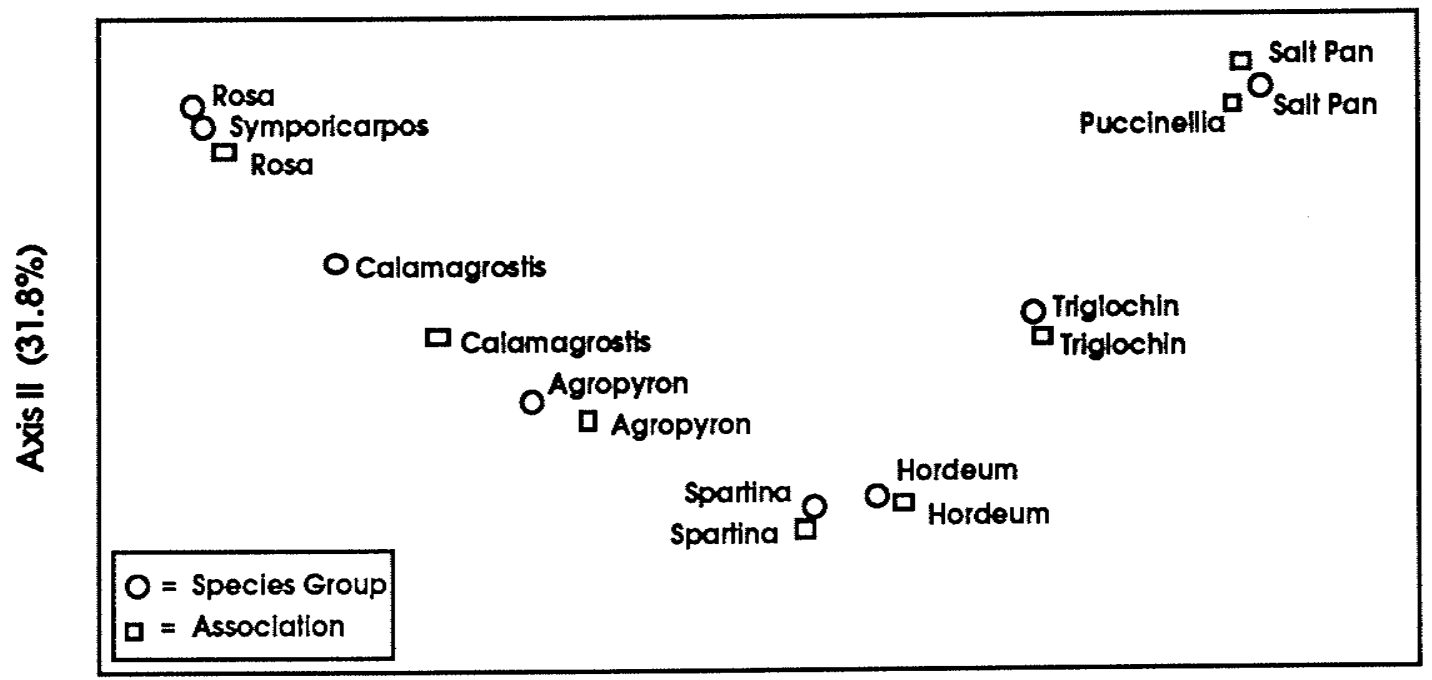

Axis I (48.8\%)

Figure 3.5. Two-dimensional concentration analysis ordination of the eight vegetation associations and eight species groups. Salinity increases from left to right. 


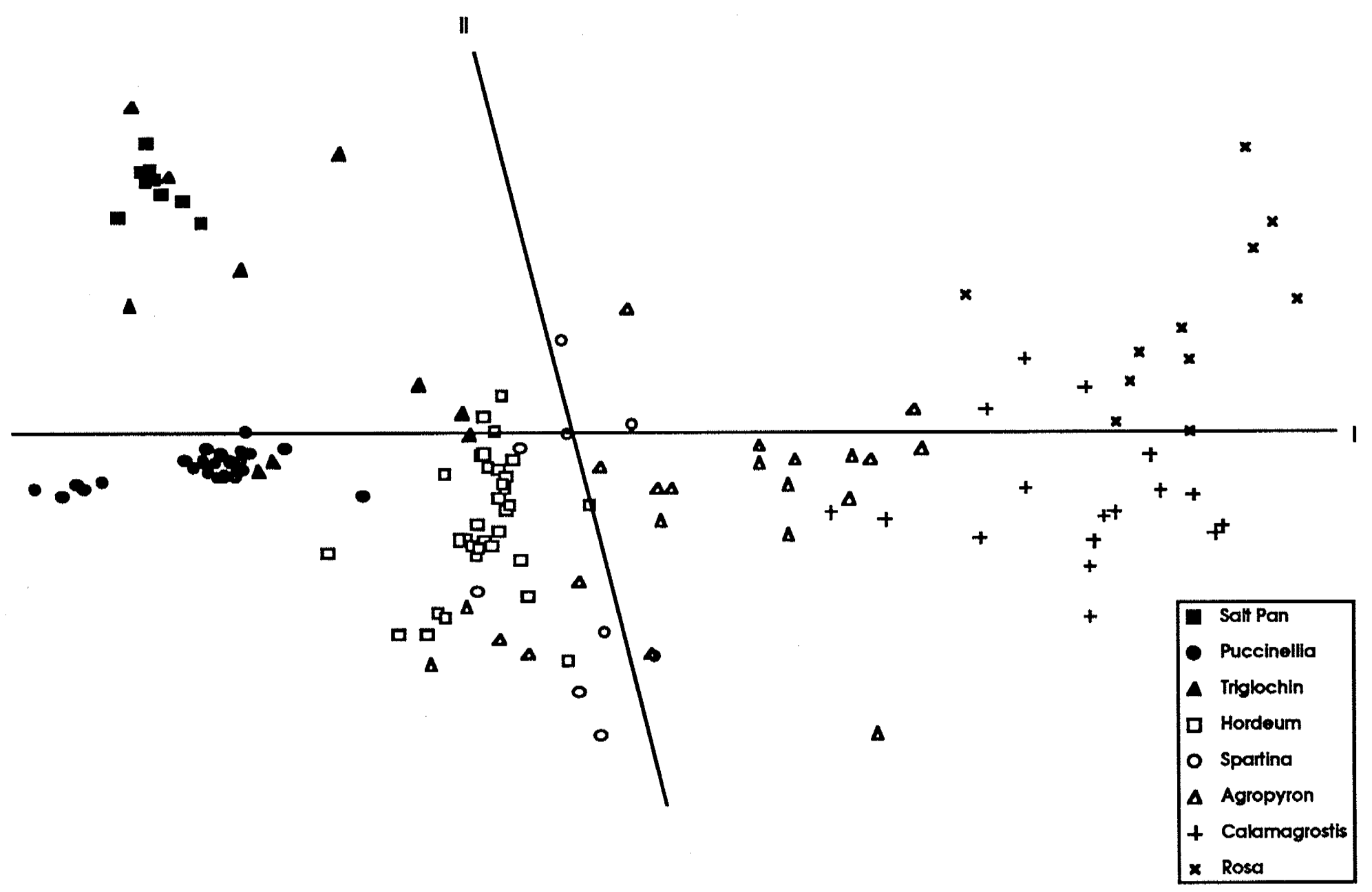

Figure 3.6. Two-dimensional nonmetric multidimensional scaling ordination of 135 quadrats, with axes I and II of canonical correlation analysis superimposed. Vegetation association affinities for quadrats are also indicated. The angle between axes I and II is $103.7^{\circ}$. 
Table 3.4 Canonical Correlation results.

\begin{tabular}{lcc}
\hline & \multicolumn{2}{c}{ Canonical Correlation Axis } \\
& \multicolumn{1}{c}{ I } & I \\
\hline Total Salts & -0.813 & 0.415 \\
$\mathrm{pH}$ & -0.756 & -0.101 \\
Relative Elevation & 0.643 & -0.026 \\
Bulk Density & -0.488 & 0.456 \\
Potassium & -0.440 & 0.328 \\
Phosphorus & 0.220 & -0.132 \\
Nitrogen & -0.170 & -0.180 \\
Percent Organic Matter & 0.145 & 0.301 \\
& & \\
\hline
\end{tabular}




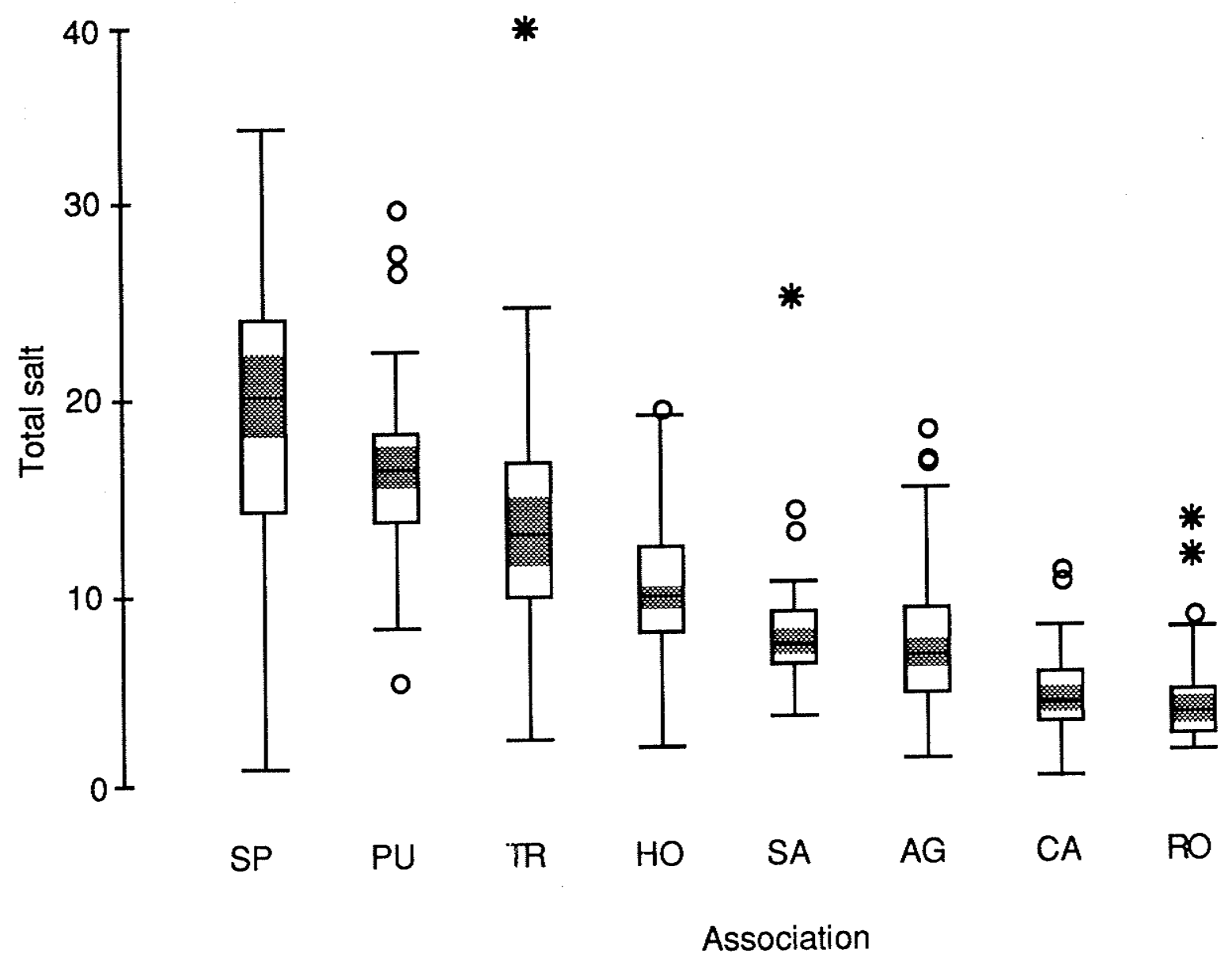

Figure. 3.7. Boxplots summarizing salinity variation among associations. Shaded areas represent the $95 \%$ confidence interval of the median. Boxes represent the interquartile range; the horizontal line within each box is the median. Whiskers extend from the box to the nearest point within $\pm 1.5 *$ interquartile range. Circles represent outliers less than $\pm 3.0 *$ interquartile range and stars are outliers greater than $\pm 3.0 *$ interquartile range. Associations: SP - Salt Pan, PU - Puccinellia, TR - Triglochin, HO - Hordeum, SA Spartina, AG - Agropyron, CA - Calamagrostis, RO - Rosa. 

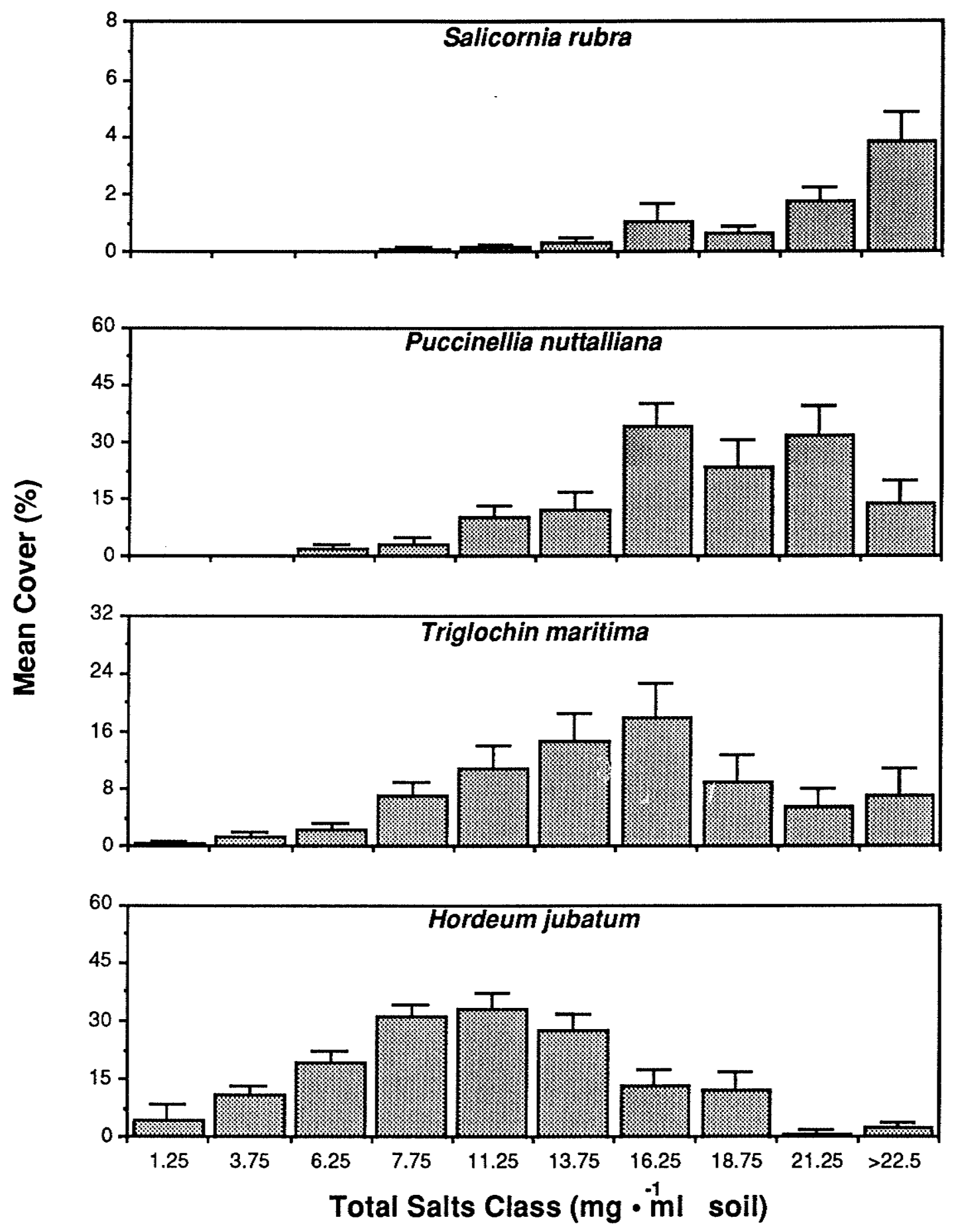

Figure 3.8. Mean percent cover $( \pm 1$ s.e.) vs. soil salinity class for the nine most frequently occurring species. 

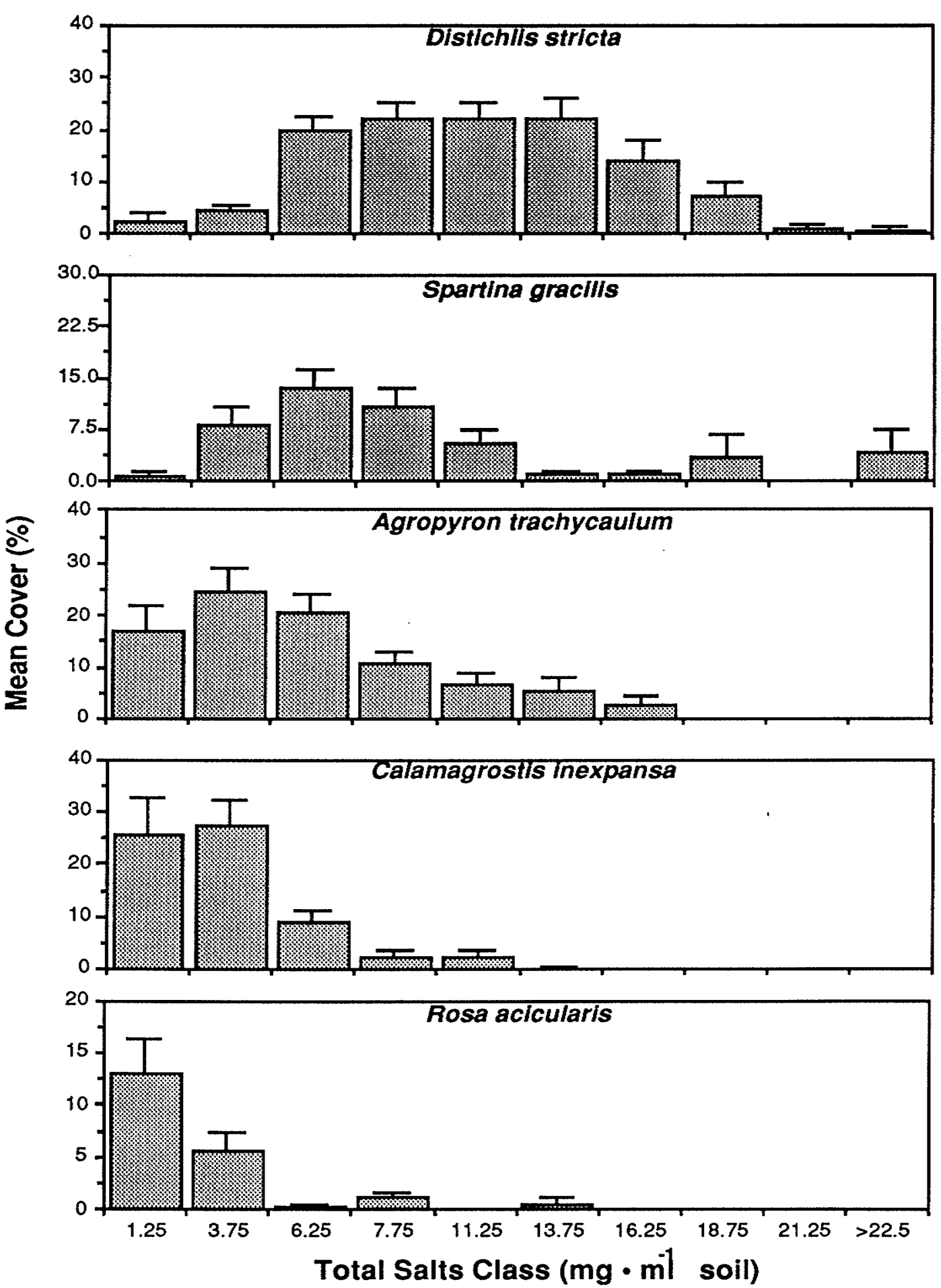

Figure 3.8 (continued). Mean percent cover $( \pm 1$ s.e.) vs. soil salinity class for the nine most frequently occurring species. 


\section{Chapter 4 \\ Discussion}

\subsection{Plant Communities of Inland Saline Sites}

My results are consistent with previous studies suggesting that soil salinity is the over riding factor determining the distribution and abundance of plant species in inland saline habitats. An inverse correlation between elevation above the salt pan and soil salinity was also noted. At higher relative elevations, improved soil drainage provides a rooting zone of low salinity which allows the establishment of less salt-tolerant species. While nutrient levels and organic matter content showed overall increases with decreasing salinity, and bulk density an overall decrease, the trends were comparatively weak.

The halophytic species composition of the salt flats is similar to that of prairie salt pans in Saskatchewan (Dodd \& Coupland 1966), Colorado and the Dakotas (Ungar 1974b), and to boreal salt flats in north-eastern Alberta (Lieffers 1984). Similarities between the vegetation of prairie and boreal salt pans suggest that soil salinity may largely override climatic and other environmental factors in determining species composition, and that species able to tolerate saline conditions have wide geographic ranges. Nonetheless, differences in structure and composition of halophytic vegetation do occur along northsouth and east-west gradients in North America (Ungar 1974b). Species of southern areas include Sporobolus airodes, S. texanus, and salt-tolerant shrubs such as Tamarix pentandra and Sarcobatus vermiculatus. Salicornia rubra is restricted to northern areas: in parts of Oklahoma, Kansas and Nebraska salt pans are dominated instead by Sesuvium verrucosum or Suaeda depressa. Species which appear to be more common in northern and western saline habitats include Glaux maritima, Puccinellia nuttalliana, Spartina gracilis, Triglochin maritima, Ambrosia psilostachya, Grindelia squarrosa, Aster pauciflorus, and Spergularia marina (Ungar 1974). The presence of Plantago maritima in 
our study area is particularly interesting, as it has a very restricted distribution inland (Harms, Hoopr \& Baker 1986).

The zonation patterns found in this study are also similar to those of other inland salt flats in north-central North America. A direct comparison is difficult, however, since none of the other studies have used clustering techniques; most the the 'communities' were defined by visual inspection prior to sampling. The most saline areas were dominated by succulent annual species (e.g. Salicornia rubra, Suaeda depressa, Spergularia marina). I also observed dwarf forms of Triglochin maritima on the open pan. However, Puccinellia nuttalliana was most abundant along the edge of salt pans, where it formed dense tufts interspersed with succulent annuals. Triglochin maritima dominated the edge of some pans, where it formed a dense, low mat interspersed with the short-lived perennials Glaux maritima and Plantago maritima and the annual Atriplex patula. Both Puccinellia nuttalliana and Triglochin maritima are common at or near the vegetation edge of salt pans throughout northern and western North America, but are absent from southern areas (Ungar 1974b). The next vegetation zone consisted of a mixture of the grasses Hordeum jubatum and Distichlis stricta with occasional individuals of Grindelia squarrosa. While Hordeum-Distichlis codominance has been noted previously (e.g. Keith 1958; Dodd \& Coupland 1966), most studies have found that these species form distinct vegetation zones (Ungar 1974a). In Saskatchewan, Distichlis stricta was also found associated with Puccinellia nuttalliana and Agropyron smithii (Dodd \& Coupland 1966). In southern areas Distichlis stricta is often found at the edge of salt pans (Ungar 1968).

Many of the associations described in this study could have been distinguished by visual examination, which is the strategy used in most previous studies of inland halophyte vegetation. The advantage of using cluster analysis to determine vegetation types is that it allows replication of field sampling and analysis. Without an objective classification schemeit would be difficult to compare this study with future studies of similar habitats. 


\subsection{Cluster analysis relation ships}

Each of the associations have few species in common with other associations. This is especially true at higher salinities, where distinct boundaries occur between the associations. Correspondence analysis results support this finding; each species groups is closely associated with a corresponding vegetation association. This indicates that there is very little overlap of species from one association to the other. The associations can be separated along an idealized gradient (Fig 4.1) running from the salt pan to the gravel ridges. The vegetation associations always occurred in the order shown.

Previous studies reveal that the species composition of less saline areas surrounding a salt pan shows much greater intersite variation than that of the more saline areas (Ungar 1974b). This suggests that whereas the vegetation of more saline areas is determined primarily by soil osmotic potential, climatic and floristic influences operating at larger spatial scales are more important when salinities are lower. The four vegetation associations occurring on less saline soils at the Winnipegosis site have not been previously described in the literature on inland saline habitats (Spartina, Agropyron, Calamagrostis, Rosa). Their species composition suggests floristic affinities with both prairie and boreal forest.

Spartina gracilis is characteristic of moist, moderately saline soils (Looman 1982) and has been found in meadows adjacent to salt pans in a number of northern areas (e.g. Dodd \& Coupland 1966). In the present study it occurred with the rare composite Aster pauciflorus and with Hordeum jubatum, Distichlis stricta and Grindelia squarrosa. Less saline areas were dominated by Agropyron trachycaulum, which is characteristic of wet meadows and is known to be somewhat salt-tolerant (Looman 1982). Although it has not been recorded in other studies of saline habitats, the related Agropyron smithii has been (Ungar 1974b). In our study, Agropyron trachycaulum was closely associated with Ambrosia psilostachya (which is occasionally encountered near saline pans in northern areas, Ungar 1974b) and the glycophyte Aster pansus. At still lower salinities the dominant grass was Calamagrostis inexpansa, which was associated with a mixture of boreal and prairie 
grasses and forbs.The Rosa acicularis-Symporicarpos alba shrub association, which occurred in areas of low salinity adjacent to gravelly ridges, is also characterized by a mixture of boreal and prairie forbs. Note that previous studies of inland saline habitats have been restricted to ares containing salt tolerant species: very few have catalogued the vegetation of the surrounding prairie regions. Studies that have included some information on surrounding non-saline areas have generally only listed the species present.

\subsection{Yegetation Gradient and Pattern}

The results of the canonical correlation indicated that salinity, $\mathrm{pH}$ and elevation were most highly correlated with vegetation variation. It should be noted that 'elevation' is a complex environmental gradient which may be a combined effect of lower salinity and better drainage. Pairwise Sheffe's tests indicated that all the communities can be separated based one one of these factors, usually salinity. In cases where salinity did not show a significant difference between the associations, one of the other factors usually did. The pairs of associations which were not significantly different in any of the measured environmental variables were Calamagrostis - Agropyron, and Puccinellia - Triglochin. These associations may differ in some unmeasured environmental variable, such as soil moisture. Competition may also be important: the presence of one species at a site may inhibit the invasion of other species.

Inland saline pans are characterized by plant communities dominated by a single (or occasionally two) species, which are ordered along the salinity gradient reflecting differing degrees of physiological salt tolerance. Many workers have noted the occurrence of vegetation discontinuities or ecotones along this gradient, even though there appears to be no discontinuities in environmental factors (Ungar 1974a). By contrast, vegetation ecotones in coastal salt marshes often correspond to tidally-imposed environmental edges, 
Figure 4.1 Idealized vegetation gradient. 
though interspecific competition may play a secondary role (Bertness \& Ellison 1987; Odum 1988). In our study area, vegetation discontinuities were apparent across the entire salinity gradient, though they were most pronounced at higher salinities (see also Flowers 1934; Ungar 1974a; Skougard and Brotherson 1979).

If environmental 'edges' do not underlie vegetational discontinuities in inland saline systems, it seems likely that biotic processes are involved in ecotone development. Indeed, recent simulation models of plant communities have suggested that competitive displacement may result in the development of vegetation ecotones along continuous environmental gradients (Czárán 1989; Smith \& Huston 1989). In Smith and Huston's model of species interaction along a moisture gradient it was assumed that all species have highest growth rate at the same 'optimal' soil moisture level, and that growth rates decrease monotonically from this optimum. However, Austin \& Smith (1989) argue that species responses along an environmental gradient are unimodal rather than monotonic, and that each species has a unique position along the gradient where its growth is optimal. This may not be true of a salinity gradient, however, since even the most salt-tolerant halophytes show optimal growth when salts are absent or in relatively low concentration; there are apparently few if any 'obligate' halophytes (Barbour 1970; Flowers et al. 1977). The graphical model of the effect of competitive interactions on the distribution of species along a salinity gradient (Fig. 4.2) assumes that salt-tolerant species are excluded from areas of low salinity through competitive exclusion by less salt-tolerant but faster growing glycophytes. With competition, the degree of species overlap decreases and ecotones develop (see also Mueller-Dumbois \& Ellenberg 1974; Walter \& Breckle 1985).

On this site it was noted that the boundaries between associations were more pronounced in areas of high soil salinity. Regions of higher soil salinity have lower species richness: clear boundaries may form as a result of low species overlap. By contrast in areas of higher richness (lower soil salinity) there may be several sub-dominant 
species occurring on both sides of the boundary between two dominant species, obscuring the boundary between associations.

\subsection{Trends in Species Richness and Diversity Along the Salinity Gradient}

The observation of a monotonic decrease in species richness with increasing salinity has been noted previously (Ungar 1974a). Given that relatively few plant species have developed the physiological adaptations necessary to survive in saline environments, it is perhaps not surprising that species richness is lower at higher salinities. The high osmotic potential of soils on the unvegetated salt pan presumably prevents any species from establishing there. For coastal marshes, Odum (1988) hypothesized a similar decrease in vascular plant species richness with increased salinity, which he attributed to greater osmotic stress in more saline habitats.

A general increase in Shannon-Weaver diversity and evenness with decreasing salinity was also noted. The one major exception to this trend was the Salt Pan association, which had a diversity similar to the Spartina and Calamagrostis associations and the highest evenness value (0.84). A possible explanation is forthcoming when one considers the mean percent cover of this association ( $16 \%$ vs. $112-158 \%$ for the others). There is likely little if any interspecific competition for available resources when plant cover is this low. When competition is unimportant, no one species dominates with the result that diversity and evenness are high (see also Strong et al. 1984, who used a similar argument to explain the high diversity and evenness of phytophagous insect communities). Six of the other associations have similar evenness values (range 0.49 - 0.71), indicating higher ShannonWeaver diversities at lower salinities are attributable mainly to increased species richness. The high evenness value of the Rosa association ( 0.82$)$ can be explained by noting that the other three low-salinity associations (Spartina, Agropyron, and Calamagrostis) are each dominated by a single rhizomatous graminoid. Species with this growth form tend to dominate sites in which they occur, with the result that evenness is low. 

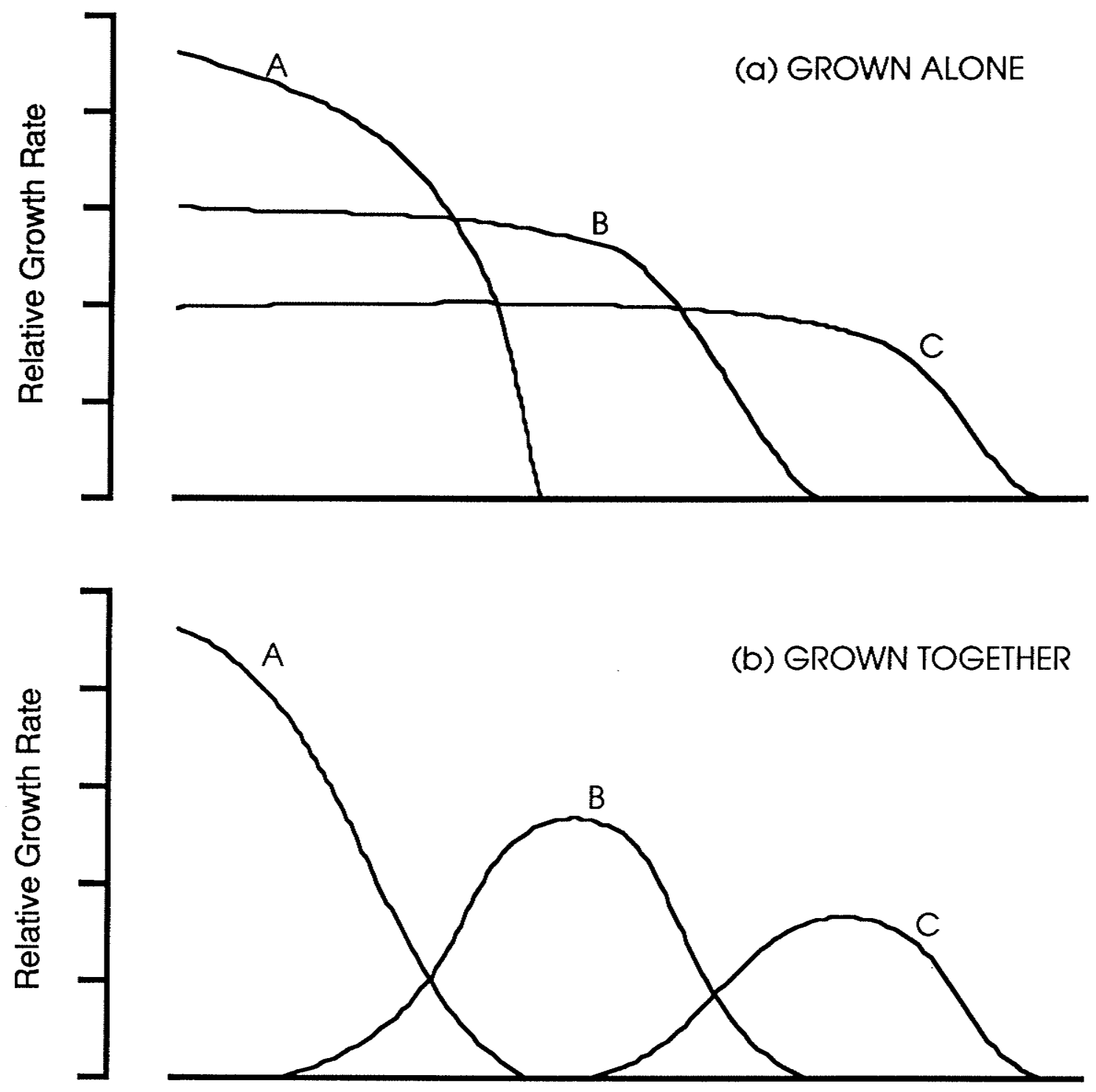

Figure. 4.2 Theoretical model of how three species would respond without competition under salinity stress and with competition and salinity stress. 
In the Rosa association, the absence of a strongly clonal species and greater stratification (owing to the presence of shrub) explain its high diversity and evenness.

\subsection{Spatial and Temporal Dynamics of Inland Saline Habitats}

A number of authors have proposed successional sequences for plant communities on saline soils in western North America (Appendix B). Early schemes generally proceeded in a linear sequence from higher to lower salinity over time, under the assumption that the observed zonation of vegetation along a salinity gradient reflected a 'successional' sequence. Later studies recognized that retrogressive change was also possible (e.g. Keith 1958). Ungar (1972) developed a model of dynamic change in which the vegetation tracks changes in environmental conditions over time. For example, a series of wet years leads to a decrease in soil salinity and a shift toward less salt-tolerant communities. Conversely, species composition reverts to that characteristic of higher salinities in dry years. I noted that in a very dry season (1988) Salicornia rubra germinated successfully but died well before setting seed (see also Ungar 1970), while during a wet season (1990) cover of this species was high. Furthermore, in 1990 seedlings of Hordeum jubatum, Puccinellia nuttalliana and Typha spp. were found on the normally unvegetated salt pans. I suggest that species are 'sorted out' along a salinity gradient according to their physiological limit of salt tolerance. Thus, it is the maximum soil salinity reached, rather than mean salinity, that ultimately determines species distributions. If this is true, the borders of vegetation zones may fluctuate from year to year but are expected to remain stable over many decades.

The seed bank may also play an important role in development and perpetuation of communities in areas of high and variable salinity (Ungar 1987). In the laboratory, I found that Salicornia rubra germinated from soil taken from the Hordeum and Puccinellia associations, while Hordeum jubatum, Puccinellia nuttalliana and Typha spp. germinated from soil taken from the unvegetated salt pan. I also observed that seed banks of 
communities dominated by annual halophytes were generally larger than those of perennial plant communities. This is not surprising, as reproduction by seed is the only mechanism by which populations of annuals are perpetuated. Long-term dormancy is apparently also important, as evidenced by the reappearance of annual species in wet years after several years of scarcity. 


\section{Chapter 5}

\section{Summary}

1. Eight vegetation associations and eight species groups were delineated using cluster analysis. Concentration analysis was used to simultaneously ordinate the vegetation associations and species groups and compare the two ordinations. Both the associations and groups produced similar results.

2. Non-metric multidimensional scaling was used to ordinate a subset of 135 quadrats. The resulting two dimensional ordination, representing the strongest trends in the data, was compared to the environmental variables using canonical correlation analysis. Salinity was found to be the over-riding factor causing a strong vegetation gradient . Relative elevation and $\mathrm{pH}$ were also highly correlated with the vegetation data.

3. Soil factors could only account for part of the change in vegetation pattern around the salt flats. It is suggested that further ordering and formation of vegetation boundaries could arise through interspecific competition and displacement mediated by differences in salt tolerance. The species that are better able to survive at high salinities may be forced to grow in saline environments because they can not compete with the species not able to tolerate salinity stress.

4. This study has indicated a strong relationship between vegetation and salinity, which manifests itself as a distinctive patterning of vegetation along the salinity gradient. It is particularly important to understand the ecological processes underlying this observed pattern. To this end, reciprocal transplant experiments in the field, and controlled growth chamber experiments, should be used to examine the role of interspecific competition in the development of vegetation boundaries along salinity gradients. In addition, seed bank studies should be carried out in an attempt to understand the dynamics of vegetation composition and structure in saline habitats. Such studies are particularly important given 
the increasing rate of soil salinization on productive farmland in the Canadian prairie provinces. 


\section{References}

Agarwal, R.R., Das, S.K. \& Mehrotra C.L. 1961, Interrelationship between electrical conductivity of $1: 5$, and saturation extracts and total soluble salts in saline-alkali soils of the gangetic alluvium in Uttar Pradesh. Indian J. agric. Sci. 31:284-296.

Ahmad, I., Larher, F., and Stewart, G.R. 1979, Sorbitol, a compatible osmotic solute in Plantago maritima. New Phytol 82:671-678.

Albert, R. 1975, Salt regulation in halohytes. Oecologia 21:57-71

Anonymous. 1987. University Manitoba Soil testing laboratory manual.

Austin, M.P. \& Smith, T.M. 1989. A new model for the continuum concept. Vegetatio 83: 35-47.

Austin, M.P. and Austin, B.O. 1980. Behavior of experimental plant communities along a nutrient gradient. J. Ecol. 68: 891-918.

Bar-Nun, Nurit and Pljakoff-Mayber, Alexandra. 1977, Salinity stress and the content of proline in roots of Pisum sativum and Tamarix tetragyna. Ann. Botany 41:173-179.

Barbour, M.G. 1970. Is any angiosperm an obligate halophyte? Am. MidI. Nat. 84:105120.

Bertness, M.D. \& Ellison, A.M. 1987. Determinants of pattern in a New England salt marsh plant community. Ecol. Monog. 57: 129-147.

Bolen, Eric G. 1964. Plant ecology of spring fed salt marshes in western Utah. Ecol. Monog. 34:143-166.

Booth, T. 1971. Taxonomic and ecological aspects of zoosporic fungi in coastal and steepe soils. Phd. Thesis, University of British Columbia. p 6.

Borchert, J.R. 1971. The dust bowl in the 1970s. Ann. Assoc. Amer. Geogr. 61: 1-22.

Bower, C.A. \& Wilcox, L.V. 1965. Soluble salts. In Methods of soil analysis. Part 2. Chemical and microbiological properties. Edited by C.A. Black. Amer. Assoc. Agron. Monograph No. 9. Amer. Assoc. Agron., Madison, WI. pp. 933-951.

Bradfield, G.E. and Kenkel, N.C. 1987. Nonlinear ordination using flexible shortest path adjustment of ecological distances. Ecology 68: 750-753.

Briens, M. and Larher, F. 1982. Osmoregulation in halophytic higher plants: a comparative study of soluble carbohydrates, polyols, betaines and free proline. Plant, Cell and Environment 5:287-992

Brotherson, J.D. and Rushforth, S.R. 1987. Zonation patterns in the vascular plant communities of Benton hot springs, Mono County, California. Great Basin Nat. 47: 583-591. 
Cargill, S.M. \& Jefferies, R.L. 1984. The effects of grazing by Lesser Snow geese on the vegetation of a sub-arctic salt marsh. J. Appl. Ecol. 21: 669-686.

Cavalieri,A.J. and Huang, H.C. 1979. Evaluation of proline accumulation in the adaptation of diverse species of marsh halophytes to the saline environment. Amer. J. Bot. $66: 307-312$.

Chang, C., Sommerfeldt, T.G., Carefoot J.M., \& Schaalje, G.B. 1983. Relationships of electrical conductivity with total disolved salts and cation concentration of sulfate dominant soil extracts. Can. J. Soil Sci. 63: 79-86.

Chapman, K.A., Dunevitz, V.L. and Kuhn, H.T. 1985. Vegetation and chemical analysis of a salt marsh in Clinton county, Michigan. Mich. Bot. 24: 135-144.

Czárán, T. 1988. Coexistence of competing populations along an environmental gradient: a simulation study. Coenoses 4: 113-120.

Davies, B. E. 1974. Loss on ignition as an estimate of soil organic matter, Soil Sci. Soc. Amer. Proc. 38:150.

Dodd, J.D., D.A. Rennie, and R.T. Coupland. 1964. The nature and distribution of salts in uncultivated saline soils in Saskatchewan. Canadian Journal of Soil Science 44:165-175.

Dodd, J.D. and Coupland, R.T. 1966. Vegetation of saline areas in Saskatchewan. Ecology, 47: 958-968.

Ecoregions Working Group. 1989. Ecoclimatic regions of Canada. First approximation. Ecological land classification series, No. 23. Environment Canada, Ottawa, Ontario.

Eilers, R. 1986. Persional communication

Emerson, J.D. and Strenio, J. 1983. Boxplots and batch comparison. In Understanding robust and explanatory data analysis. Edited by D. Hoglin, F. Mosteller, and J.W. Tukey. J. Wiley and Sons, New York, N.Y. pp. 58-77.

Environment Canada. 1982. Canadian climate normals 1951-1980. Canadian climate program, Atmospheric Environment Service, Ottawa, Ontario.

Everdingen, R.O. van. 1971. Surface-water composition in southern Manitoba reflecting discharges of saline subsurface waters and subsurface solution of evaporites. In Geological studies in Manitoba, Special paper No. 9. Edited by A.C. Turnock. Geol. Assoc. Canada, Ottawa, Ontario. pp. 343-352.

Ewing, I. \& Kershaw K.A. 1986. Vegetation patterns in James Bay coastal marshes I Environmental factors on the south coast. Can. J. Bot. 64: 217-226.

Feoli, E. and Orlóci, L. 1979. Analysis of concentration and detection of underlying factors in structured tables. Vegetatio 40: 49-54.

Flowers, S. 1934. Vegetation of the Great Salt Lake region. Bot. Gaz. 95: 353-418. 
Flowers, T.J., Troke, P.F. and Yeo, A.R. 1977. The mechanism of salt tolerance in halophytes. Ann. Plant Physiol. 28: 89-121.

Gittins, R. 1985. Canonical analysis. A review with applications in ecology. Biomathematics 12. Springer-Verlag, Berlin.

Glenn, E. P. and O'Leary, J. W. 1984. Relationship between salt accumulation and water content of dicotyledonous halophytes. Plant, Cell and Environment 7: 253-261.

Glenn, E.P. 1987. Relationship between cation accumulation and water content of salttolerant grasses and a sedge. Plant, Cell \& Environment 10: 205-212.

Glooschenko, W.A. \& Martini, I.P. 1987. Vegetation of river influcenced coastal marshes of the south western end of James Bay Ontario. Wetlands 7: 71-84

Gosselink, J.G., Hatton, R. and Hopkinson, C.S. 1984. Relationship of organic carbon and mineral content to bulk density in Louisiana marsh soils. Soil Sci. 137: 177180.

Greenway H. and Osmond, C. B. 1972. Salt response of enzymes from species differing in salt tolerance. Plant Physio. 48: 256-259.

Haines, B.L. and Dunn, E.L. 1976. Growth and resource allocation responses of Spartina alterniflora Loisel. to three levels of $\mathrm{NH} 4-\mathrm{N}, \mathrm{Fe}$ and $\mathrm{NaCl}$ in solution culture. Bot. Gaz. 137: 224-230.

Hammer, U. Theodore. 1978. The saline lakes of Saskatchewan 1. Background and ratinale for saline lakes research. Int. Revue ges. Hydrobiol. 63: 173-177.

Harms, V.L., Hooper, D.F. and Baker, L. 1986. Plantago maritima and Carex mackenzii new for Saskatchewan: additional rare inland stations for two seacoast salt marsh species. Rhodora, 88: 315-323.

Henry, L., Harron, B. and Flaten, D. 1987. The nature and management of salt-affected land in Saskatchewan. Sask. Agric., Agdex 518, Saskatoon, Saskatchewan.

Hermy, M. 1988. Accuracy of visual cover assessments in predicting standing crop and environmental correlation in deciduous forests. Vegetatio 75:57-74.

Hill, M.O. 1974. Correspondence analysis: a neglected multivariate method. J. Roy. Stat. Soc. Ser. C 23: 340-354.

Jefferies, R.L. and Rudmik T. 1984. The responses of halophytes to salinity: An ecological perspective $I n$ : Salinity tolerance in plants. Edited by. R.C. Staples and G.H. Toenniessen, John Wiley \& Sons, New York.

Jefferies, R.L. 1980. The role of organic solutes in osmoregulation in halophytic higher plants. In: Genetic engineering of osmoregulation. Edited by R.W. Rains, R.C. Valintine and A. Holaeander. Plenum Pub. Corp. New York. pp 135-154.

Jefferies, R.L. 1981. Osmotic adjustment and the response of halophytic plants to salinity. Bioscience 31: 42-46. 
Jefferies, R.L., Rudmik, T. and Dillon E.M. 1979. Responses of halophytes to high slinities and low water potentials. Plant Physio. 64:989-994.

Juhász-Nagy, P. and Podani, J. 1983. Information theory methods for the study of spatial processes and succession. Vegetatio 51: 129-140.

Keith, L. B. 1958. Some effects of increasing soil salinity on plant communities. Can. J. Bot. 36:7 9-89.

Kenkel, N.C. \& Booth, T. 1987. A comparison of presence-absence resemblance coefficients for use in biogeographical studies. Coenoses 2: 25-30

Kenkel, N.C. and Burchill, C.A. 1990. Rigid rotation of nonmetric multidimensional scaling axes to environmental congruence. Abst. Bot. (Budapest). 14: 109 -119.

Kenkel, N.C. and Orlóci, L. 1986. Applying metric and nonmetric multidimensional scaling to ecological studies: some new results. Ecology, 67: 919-928.

Kenkel, N.C., Juhász-Nagy, P. and Podani, J. 1989. On sampling procedures in population and community ecology. Vegetatio $83: 195-207$.

Kenkel, N.C., Mcllrath A., Burchill, C.A., Jones, G. 1990. Competition and the response of three plant species to a salinity gradient. Submited to Can. J. Bot. April 91 .

Kershaw, K.A. 1975. Vegetation zonation of the East Pen island salt marshes Hudson Bay. Cin. J. Bot. 54:5-13.

Leiffers, V.J. \& Shay, J.M. 1982 Distribution and variation in growth in Scirpus maritimus var. paludosus on the Canadian prairies. Can. J. Bot. 60: 117-125

Lieffers, V.J. 1981 Environment and ecology of Scirus martimus var. paludosus in saline wetlands of the Canadian prairies. ph.D. Thesis, Univ. Manitoba, Winnipeg, Manitoba p. 167.

Lieffers, V.J. 1984. Emergent plant communities of oxbow lakes in northeastern Alberta: salinity, water-level fluctuation, and succession. Can. J. Bot. 62: 310-316.

Looman, J. 1982. Prairie grasses identified and described by vegetative characters. Agric. Canada, Publ. 1413. Ottawa, Ontario.

Looman, J. and Best, K.F. 1987. Budd's flora of the Canadian prairie provinces. Agric. Canada, Publ. 1662, Ottawa, Ontario.

Macke, A.J. and Ungar, I.A. 1971. The effects of salinity on germination and early growth of Puccinellia nuttalliana. Can. J. Bot. 49: 515-520.

McKell, C.M., Goodin, J.R. and Jefferies, R.L. 1986. Saline land of the United States of America and Canada. Reclam. Reveget. Res. 5: 159-165.

McMahon, Karen A., and Ungar, I.A. 1978. Phenology, Distribution and survival of Atriplex triangularis Willd. in an Ohio salt pan. Amer. Midl. Nat. 100:1-14 
Mehlich, A. 1973. Uniformity of soil test results as influenced by volume weight. Commun. Soil Sci. Plant Anal. 4: 475-486.

Mueller-Dumbois, D. and Ellenberg, H. 1974. Aims and methods of vegetation ecology. J. Wiley and Sons, New York, NY.

Neter, J. and Wasserman, W. 1974. Applied linear statistical models. R. D. Irwin, Homewood, IL.

Odum, W.E. 1988. Comparative ecology of tidal freshwater and salt marshes. Ann. Rev. Ecol. Syst. 19: 147-176.

Orlóci, L. 1967. An agglomerative method for classification of plant communities. J. Ecol. 55: 193-206.

Palmer, M. W. 1990. The estimation of species richness by extrapolation. Ecology 71: 1195-1198.

Pearson, W.J. 1963. Salt deposits in Canada. In Symposium on salt. Edited by A.C. Bersticker, K.E. Hoekstra and J.F. Hall. Northern Ohio Geol. Soc. Inc., Cleveland, OH. pp. 197-239.

Pielou, E.C. 1977. Mathematical ecology. J. Wiley and Sons, New York, NY.

Riehl, T.E. and Ungar, I.A. 1982. Growth and ion accumulation in Salicornia europaea under saline field conditions. Oecologia 54:193-199.

Riehl, T.E. and Ungar, I.A. 1983. Growth, water potential and ion accumulation in the inland halophyte Atriplex triangularis under saline field conditions. Acta Gecologica Ecol. Plant. 4:27-39.

Rowe, J.S. 1972. Forest regions of Canada. Can. For. Serv. Publ. 130. Ottawa, Ontario.

SAS Institute Inc. 1985. SAS user's guide: statistics. Version 5 edition. - Cary, NC.

Schaffner, J.H. 1898. Notes on the salt marsh plants of northern Kansas. Botanical Gazzette 25:255-260

Shupe, J.B., Brotherson, J.D. and Rushforth, S.R. 1986. Patterns of vegetation surrounding springs in Goshen Bay, Utah County, Utah USA. Hydrobiologia 139:97-107.

Silander, J.A. and Antonovics, J. 1982. Analysis of interspecific interactions in a coastal plant community - a perturbation approach. Nature 298: 557-560.

Skougard, M.G. and Brotherson, J.D. 1979. Vegetational response to three environmental gradients in the salt playa near Goshen, Utah County, Utah. Great Basin Nat. 39: 44-58.

Smith, T. and Huston, M. 1989. A theory of the spatial and temporal dynamics of plant communities. - Vegetatio 83: 49-69. 
Snow, A.A. and Vince, S.W. 1984. Plant zonation in an Alaskan salt marsh. II. An experimental study of the role of edaphic conditions. J. Ecol. 72: 669-684.

Stewart, G.R., Lee, J.A. 1974. The role of proline accumulation in halophytes. Planta 120:279-289.

Strong, D.R., Lawton, J.H. and Southwood, T.R.E. 1984. Insects on plants: community patterns and mechanisms. Blackwell, Oxford.

Ungar, I.A. 1962 Influence of salinity on seed germination in succulent halophytes. Ecology 43: 763-764.

1965. An ecological study of the vegetation of the big salt marsh, Stafford County, Kansas. The University of Kansas Science Bulletin 56: 1-99.

1966. Salt tolerance of plants growing in saline areas of Kansas and Oklahoma. Ecology 47: 154-155.

1967. Vegetation-soil relationships on saline soils in northern Kansas. The American Midland Naturalist 78: 98-120.

1968. Species-soil relationships on the salt plains of northern Oklahoma. Am.

Midl. Nat. 80: 492-406.

1970. Species-soil relationships on sulfate dominated soils of South Dakota. Am.

Midl. Nat. 83: 343-357.

1972. The vegetation of inland saline marshes of North America, north of Mexicu. In Grundfragen und Methoden in der Pflanzensoziologie. Edited by R. Tuxen. W. Junk, The Hague. pp. 351-363.

1973. Salinity tolerance of inland halophytic vegetation of North America. Bull. Soc. Bot (Fr) 120: 217-222.

1974ạ. Inland halophytes of the United States. In Ecology of halophytes. Edited by R.J. Reinold and W.H. Queen. Academic Press, New York, NY. pp. 235-306.

1974b. Halophyte communities of Park County, Colorado. Bull. Torrey Bot. Club, 101:145-152.

1978. The effect of competition and salinity on the growth of a salt marsh plant species. Oecologia 37: 93-99.

1979. Seed dimorphism in Salicornia europea. Bot. Gaz. 140:102-108

1982. Germination of halophytes. In: Contributions to the ecology of halophytes. Edited by D.N. Sen and K. Rajpurohit. Junk, The Hague. pp 143-154.

1987. Population ecology of halophyte seeds. Bot. Rev. 53: 301-334. 
1988. Germination Ecology of Halophytes. In Contributions to the ecology of halophytes. Edited by D.N. Sen and K. Rajpurohit. Junk, The Hague, Netherlands pp 143-154.

Ungar, I.A., Hogan, W. and McClelland, M. 1969. Plant communities of saline soils at Lincoln, Nebraska. The American Midland Naturalist 82:564-577.

Ungar, I.A., Benner, D.K. and McGraw, D.C. 1979. The distribution and growth of Salicornia europaea on an inland salt pan. Ecology 60: 329-336.

Waite, D.T. (ed). 1986. Evaluating saline waters in a plains environment. Canadian Plains Proceedings 17, University of Regina.

Walter, H. and Breckle, S-W. 1985. Ecological systems of the geobiosphere. Vol. 1. Ecological principles in global perspective. Springer-Verlag, Berlin.

Wartenberg, D., Ferson, S., and Rolf, F.J. 1987. Putting things in order: A critique of edtrended correspondence analysis. The American Naturalist 129:434-448.

Yeo, A.R. 1983. Salinity resistance: physiologies and costs. Physiol. Plant. 58: 214-222. 


\section{Appendix A}

\section{Halophyte communities of North America}

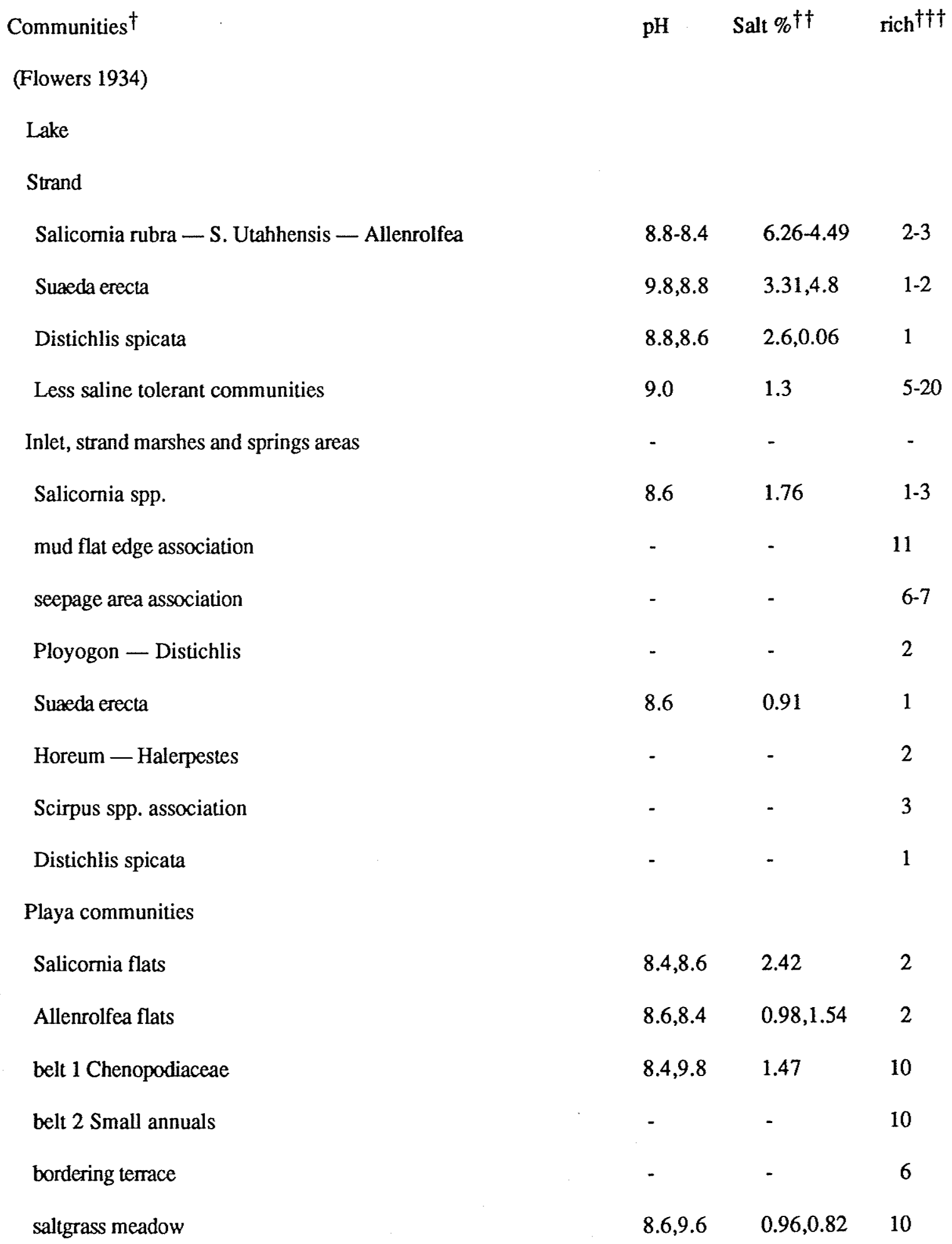


Sporobolus field

Alkali plains

Kochia flat association

greaewood - shadscale association

Kochia - Eurotia communities

Rabbit-brush community

Dunes

Delta communities

Salt marsh and sloughs

mineral springs $\begin{array}{lll}8.2,8.6 & 0.26,1.62 \quad 12\end{array}$

$8.6,9.4 \quad 0.21,0.83 \quad 26$

$\begin{array}{lll}- & 0.1,0.3 & 30\end{array}$

(Keith 1958)
Salicornia
Suaeda - Chenopodium
Distichlis
Hordeum
Praire

(Bolen 1964)

Distichlis communities

Distichlis meadow

Distichlis-Sporobolus

Distichlis-Allenrolfea

Distichlis-Salicomia

Juncus meadow

Phragmites

Juncus border

$\begin{array}{lcc}\mathrm{pH} & \text { salts \% } & \text { rich } \\ 7.0 & 1.90 & 1 \\ 7.1 & 1.45 & 4 \\ 8.2 & 1.0 & 4 \\ 6.8,7.6 & 0.26,0.52 & 17+ \\ 5.7 & \text { neg } & -\end{array}$

$\mathrm{pH}$ mmho rich

$\begin{array}{lll}8.7 & 6.96 & 7\end{array}$

$\begin{array}{lll}8.5 & 4.23 & 7\end{array}$

$\begin{array}{lll}8.6 & 2.92 & 6\end{array}$

$\begin{array}{lll}8.4 & 2.73 & 5\end{array}$ 


\begin{tabular}{lllc} 
Eleocharis meadows & 7.5 & 1.64 & 7 \\
Emergent marsh & $7.2-8.4$ & $1.3-0.75$ & $3-5$ \\
Submersed & 8.1 & 0.92 & 5 \\
Plateau sequence & - & - & - \\
Desert Upland Communities & - & - & $31+$ \\
& & & \\
(Ungar 1965) & & & rich \\
Suaeda depressa & $8 \mathrm{Halts} \%$ & 2 \\
Distichlis stricta-Suaeda depressa & $8.0-8.8$ & 1.92 & 12 \\
Scirpus paludosus - Distichlis stricta & $7.5-8.6$ & $0.49-1.55$ & 9 \\
Tall Distichlis stricta & $8.3-8.6$ & $0.27-1.10$ & 9 \\
Spartina pectinata - Distichlis stricta & $7.2-8.6$ & $0.29-0.63$ & 10 \\
Scirpus americanus - Eleocharis rostellata & $8.0-8.5$ & $0.2-0.63$ & 25 \\
Sporobolus airoides & $7.6-7.9$ & $0.18-0.68$ & 89 \\
Sandhill mixed prairie & $6.5-7.9$ & $0.04-0.19$ & 14 \\
Grazed Sandhill & $6.3-6.9$ & $0.003-0.02$ & 111 \\
\hline & 6.5 & neg & 71
\end{tabular}

(Dodd and Coupland 1966, Dodd, Rennie and Coupland 1964)
Samphire (Salicomia rubra)
Arrow-grass (Triglochin maritima)
Nutall alkaligrass (Puccinellia aroides)
Nuttal alkaligrass - saltgrass (Puccinellia - Distichlis)
Desert saltgrass - wheatgrass (Distichlis - Agropyron)
Desert saltgrass (Distichlis stricata)
Foxtail barley (Hordeum jubatum)
Prairie bulrush (Scirpus paludosa)

$\begin{array}{ccc}\mathrm{pH} & \text { mmho } & \text { rich } \\ 8.3 & 39.8 & 12 \\ 8.2 & 31.8 & 14 \\ 8.3 & 28.1 & 28 \\ 8.3 & 23.1 & 26 \\ 7.9 & 14.9 & 36 \\ 8.2 & 18.7 & 27 \\ 8.1 & 16.5 & 23 \\ 7.9 & 11.7 & -\end{array}$


Mat muhly (Muhlenbergia richardsonis)

Wheatgrass

Wheatgrass - mat muhly

Wheatgrass - greasewood (Agropyron spp. - Sarcobatus)

Mat muhly - salt grass

(Ungar 1967)

Suaeda depressa

Tamarix pentandra

Dwarf Distichlis stricta

Sporobolus texanus

Dense Distichlis stricta

Dense Suaeda depressa

Hordeum jubatum - Atriplex patula

Hordeum jubatum - Iva annua - Distichlis stricta

Scirpus paludosus

Scirpus americanus

Agropyron smithii — Prairie

(Ungar 1968)

Sesuvium verrucosum

Suaeda depressa

Scirpus paludosus

Distichlis stricta

Tamarix pentandra

Sporobolus airoides

Distichlis - Hordeum
8.0

7.4

8.1

7.9

7.7

2.0

6.3

3.6

23

36

$\mathrm{pH} \quad$ salts \% $\quad$ rich

7.8

2.52

1

$8.3 \quad 2.52$

8.8

2.4

3

7.6

1.74

7.6

0.66

5

7.6

0.51

7.7-7.8

7.3

7.8

8.3

7.7

$0.47-0.57 \quad 8$

0.49

9

0.48

6

$\mathrm{pH}$

0.3

0.06
8.1

8.1 salts \% rich

$$
2.22
$$

1.62

1.57

1.27

1.05

0.72

2

1

2 $\begin{array}{lll}8.2 & 0.19 & 7\end{array}$

$\begin{array}{lll}8.2 & 1.27 & 5\end{array}$

$\begin{array}{lll}8.4 & 1.05 & 7\end{array}$

$\begin{array}{lll}8.1 & 0.72 & 4\end{array}$




\author{
Sporobolus - Distichlis \\ Prairie \\ (Ungar, Hogan and McClelland 1969) \\ Suaeda depressa \\ Dwarf Distichlis stricta \\ Scirpus paludosus \\ Salicomia rubra \\ Hordeum jubatum - Iva annua \\ Distichlis stricta \\ Prairie - Distichlis \\ Ruppia maritima - potamogeton pectinatus \\ Typha latifolia
}

(Ungar 1970)

Salicomia rubra

Suaeda depressa

Puccinellia nuttalliana

Dwarf Distichlis stricta

Potamogeton pectinatus

Scirpus paludosus

Distichlis stricta - Hordeum jubatum

Distichlis - Agropyron

Prairie

Phragmites communis

(Ungar 1974)

$\begin{array}{lll}8.7 & 0.04 & 6 \\ 7.9 & - & 18+\end{array}$

$\mathrm{pH} \quad$ salts \% rich

$\begin{array}{lll}7.6 & 3.7 & 3\end{array}$

$\begin{array}{lll}7.7 & 4.2 & 3\end{array}$

$\begin{array}{lll}6.5 & 1.9 & 6\end{array}$

$\begin{array}{lll}7.5 & 1.6 & 5\end{array}$

$\begin{array}{lll}7.5 & 0.7 & 9\end{array}$

$\begin{array}{lll}7.9 & 0.6 & 9\end{array}$

$\begin{array}{ll}7.7 & 0.1\end{array}$

$\begin{array}{lll}7.8 & 0.3 & 2\end{array}$

$\begin{array}{lll}6.6<0.05 & 1\end{array}$

pH $\quad$ salts \% rich

$\begin{array}{lll}8.4 & 4.8 & 5\end{array}$

$8.3 \quad 4.1$

$\begin{array}{lll}8.2 & 2.8 & 6\end{array}$

$\begin{array}{lll}8.3 & 2.8 & 4\end{array}$

$\begin{array}{ll}8.9 & 2.8\end{array}$

$\begin{array}{lll}8.4 & 1.4 & 1\end{array}$

$\begin{array}{lll}7.9 & 1.1 & 11\end{array}$

$\begin{array}{lll}7.7 & 1.1 & 13+\end{array}$

$\begin{array}{lll}7.4 & 0.01 & 13+\end{array}$

$\begin{array}{ll}7.3 & 0.02\end{array}$

$\mathrm{pH} \quad$ salts \% $\quad$ rich 
Distichlis

Salicorna

Triglochin

Puccinellia

Plains Grassland

(Skougard and Brotherson 1979)

Allenrolfea occidentalis

Salicornia pacifica

Playa and Salicomia rubra

Distichlis spicta

Atriplex tridentata

Sarcobatus verminiculatus

Suaeda fruticosa

Atriplex confertifolia

Distichlis stricta and forbs

they also broke the communities up into salt tolerance groups

Low (Sporobolus, Bromus, Sitanion, Opuntia etc...)

Middle (Chenopodium, Atriplex patula, Distichlis etc...)

High (Suaeda, Poa, Triglochin, Puccinellia etc...)

very High (Allenrolfea, Salicornia rubra)

(Chapman, Dunevitz and Kuhn 1985)

Upland Marsh

Halozone marsh

Transition
7.7

2.9

7.6

2.8

8.1

8.1

7.5

0.1

$1.6-2.1$

8

1

0.7

3

.5

$\mathrm{pH} \quad$ salts \% rich

$8.42-8.69 \quad 2.6-2.7$

$>9.0$

2.6

8.79

$2.2-2.6$

$8.24-8.59$

$0.12-2.6$

$0.9-1.8$

$0.6-1.1$

8.17-8.35

$0.3-1.5$

- $\quad 0.07-0.4$ 
Halozone edge

Halozone

Center

(Shupe, Brotherson and Rushforth 1986)

Juncus, Distichlis, Muhlenbergia (Zone 3)

Scirpus americanus (Zone 1)

Eleocharis palustris (Zone 2)

(Brotherson and Rushforth 1987)

Eleocharis palustris (zone 2)

Distichlis stricta-Juncus balticus (zone 4)

Distichlis-Chrysothamnus nauseosus (zone 5)

Distichlis stricta (zone 5)

Desert (zone 5)

Mixed species meadow (zone 3)

Lilly pad/algal mat

Scirpus americanus (zone 1)
6.6-6.5 $\quad 19.2,19.1$

$\begin{array}{lll}5.7-7.1 & 18.6-22.8 & 15(8)\end{array}$

$\begin{array}{lll}5.7-6.2 & 19.35-20.65 \quad 8\end{array}$

$\mathrm{pH} \quad \mathrm{mg} / \mathrm{L} \quad$ rich

$\begin{array}{lll}8.08 & 4902 & 22\end{array}$

$\begin{array}{lll}7.02 & 2061 & 9\end{array}$

$\begin{array}{lll}7.32 & 1310 & 21\end{array}$

$\mathrm{pH} \quad$ salt (ppm) rich

$\begin{array}{lll}9.4 & 3010 & 9\end{array}$

$\begin{array}{lll}3.9 & 1500 & 7\end{array}$

$\begin{array}{lll}6.5 & 810 \quad 16\end{array}$

$\begin{array}{lll}7.5 & 802 & 11\end{array}$

1

$\dagger_{\text {Most communities are based on apriori community classification }}$

†tSalt contend has been expressed as the percent of soluble solids per dry weight of the sample. The exceptions are: Bolen 1964, 1:5 soil extract; Dodd, Rennie \& Coupland 1964, mmho from a saturated paste extract, Chapman 1985, grams soluble solids per kilogram soil; Shupe, Brotherson \& Rushforth 1986, mg soluble salts per liter; Brotherson 1987, soluble salts per million soil.

$f_{\dagger}$ Rich is the total number os species found in the individual community. 


\section{Appendix B}

\section{Succesional sequences}

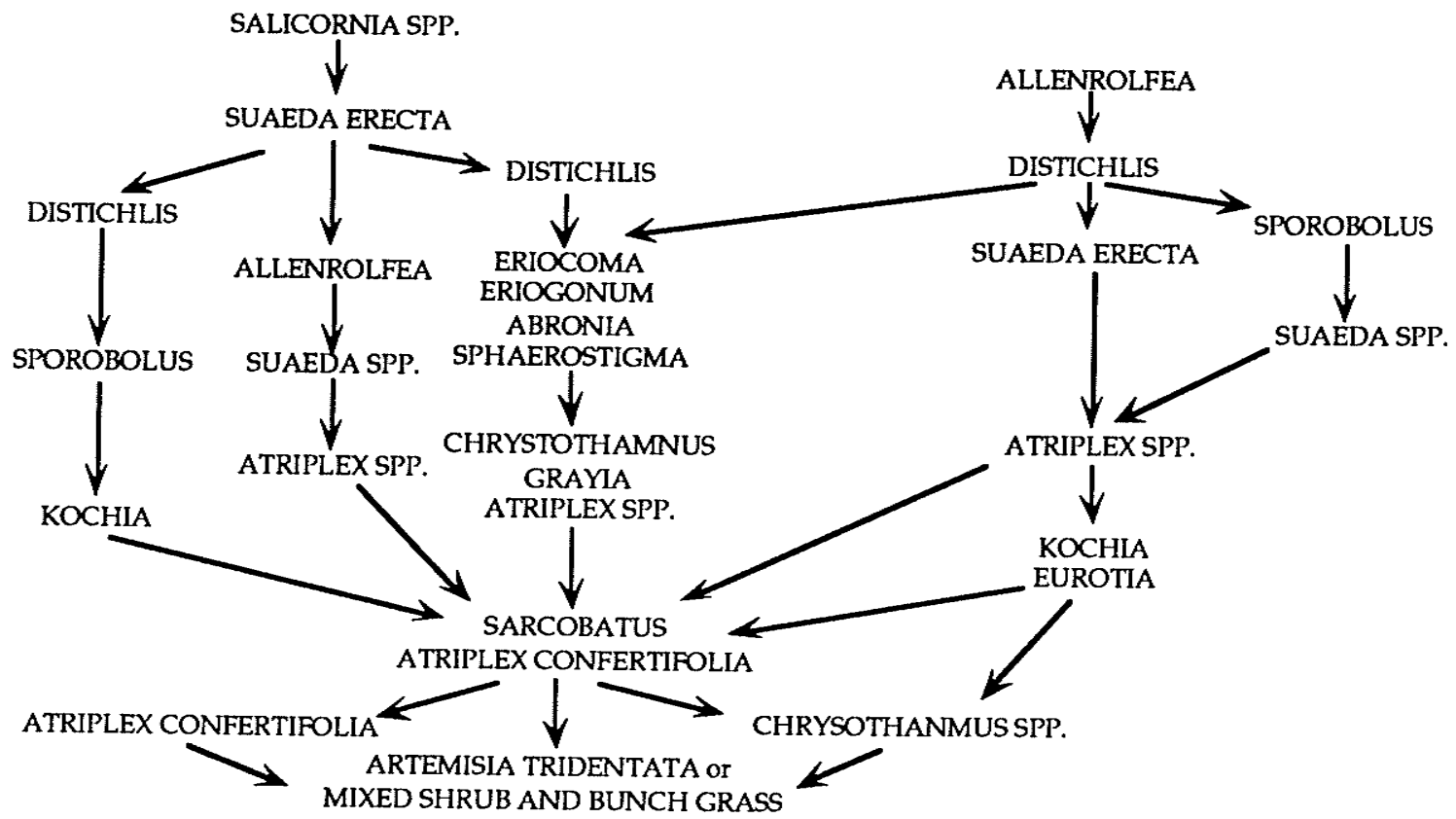

Successional scheme for saline areas of the Great Salt Lake, Utah (adapted from

Flowers, 1934).

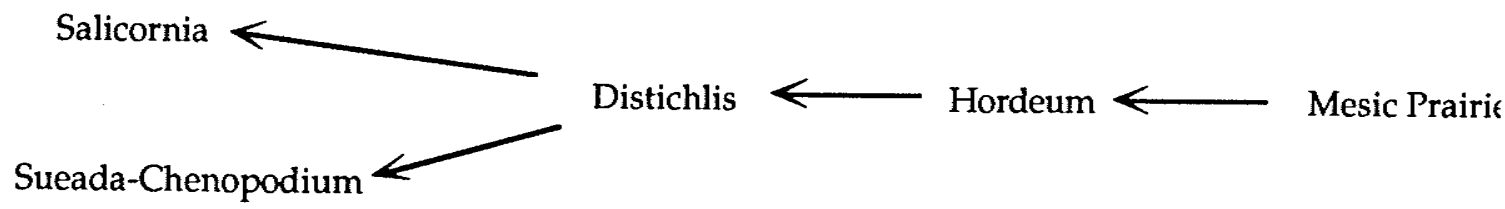

A hypothetical regression sequence from Alberta (adapted from Keith 1958). 


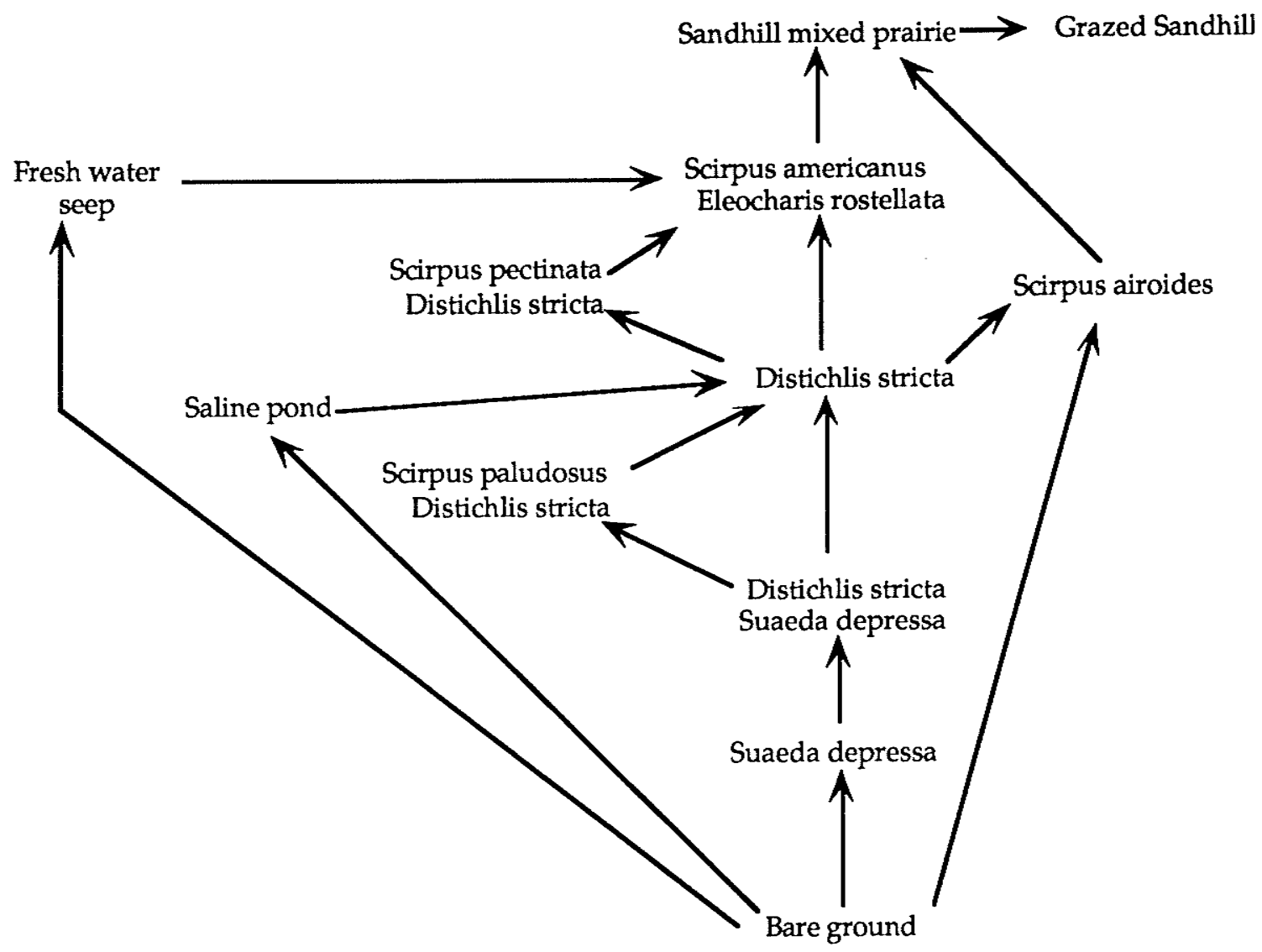

A hypothetical scheme of the major successional trends on the Big Salt Marsh.(adapted from Ungar 1965). 


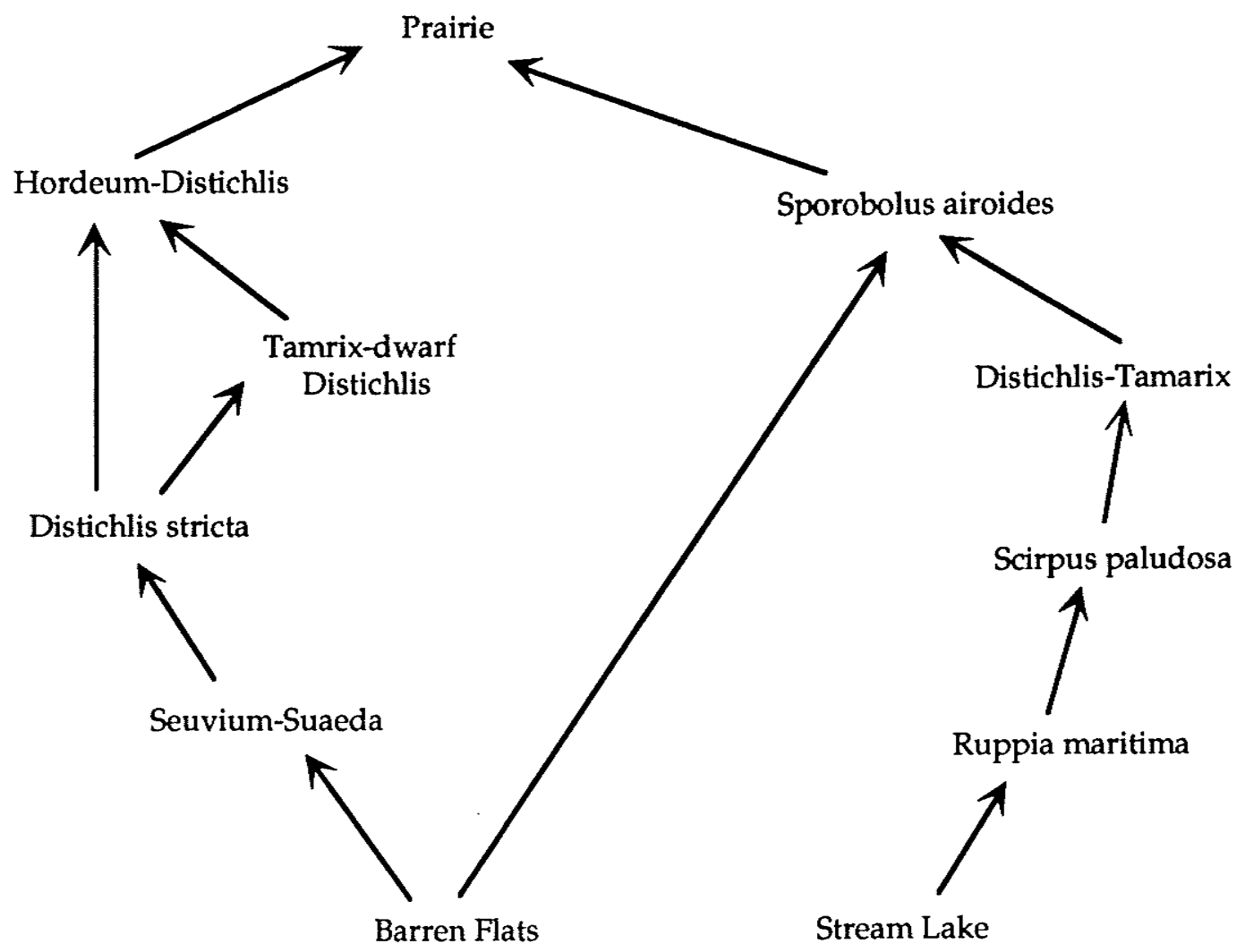

A possible succesional scheme based on vegetation zonation around the Great Salt Plain: Oklahoma (adapted from Ungar 1968). 


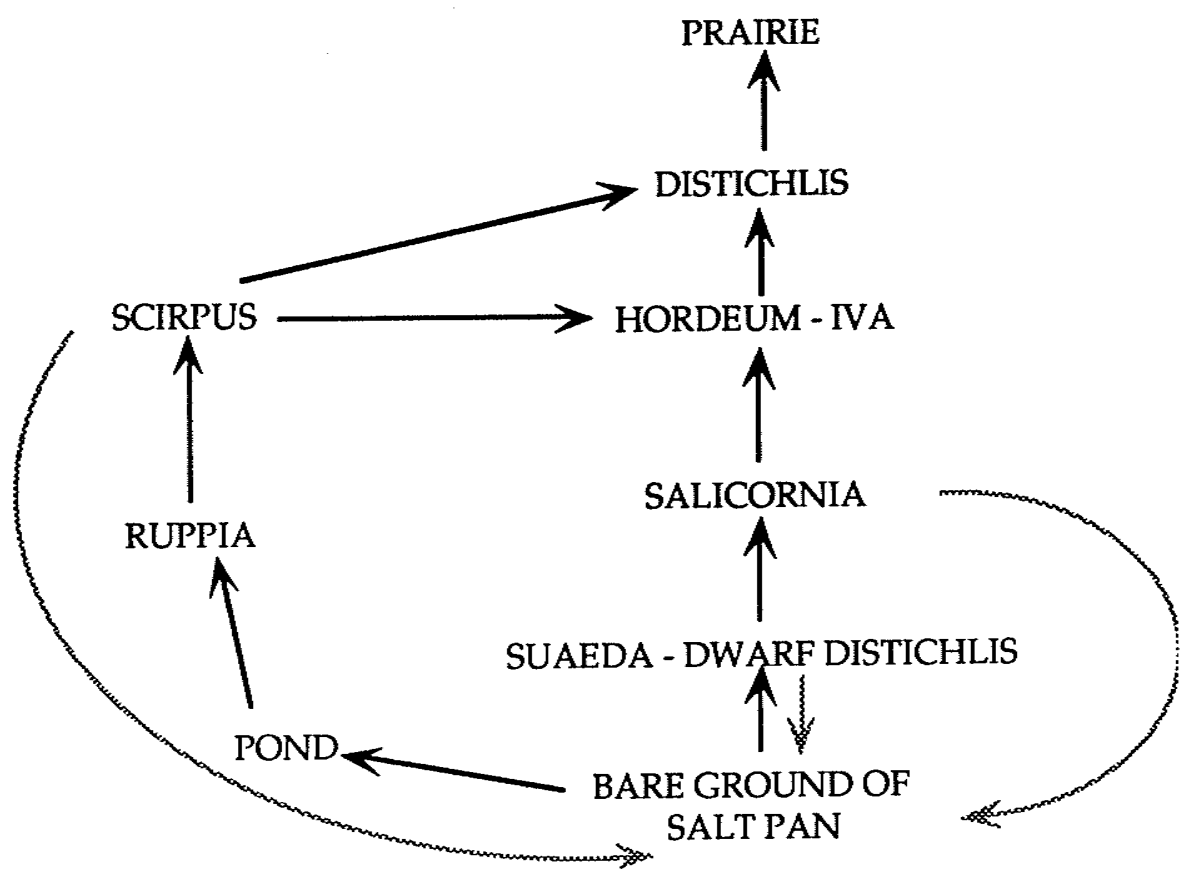

A hypothetical scheme for vegetational dynamics in the Lincoln Marsh area. (adapted from Ungar, Hogan, and McClelland 1969). 


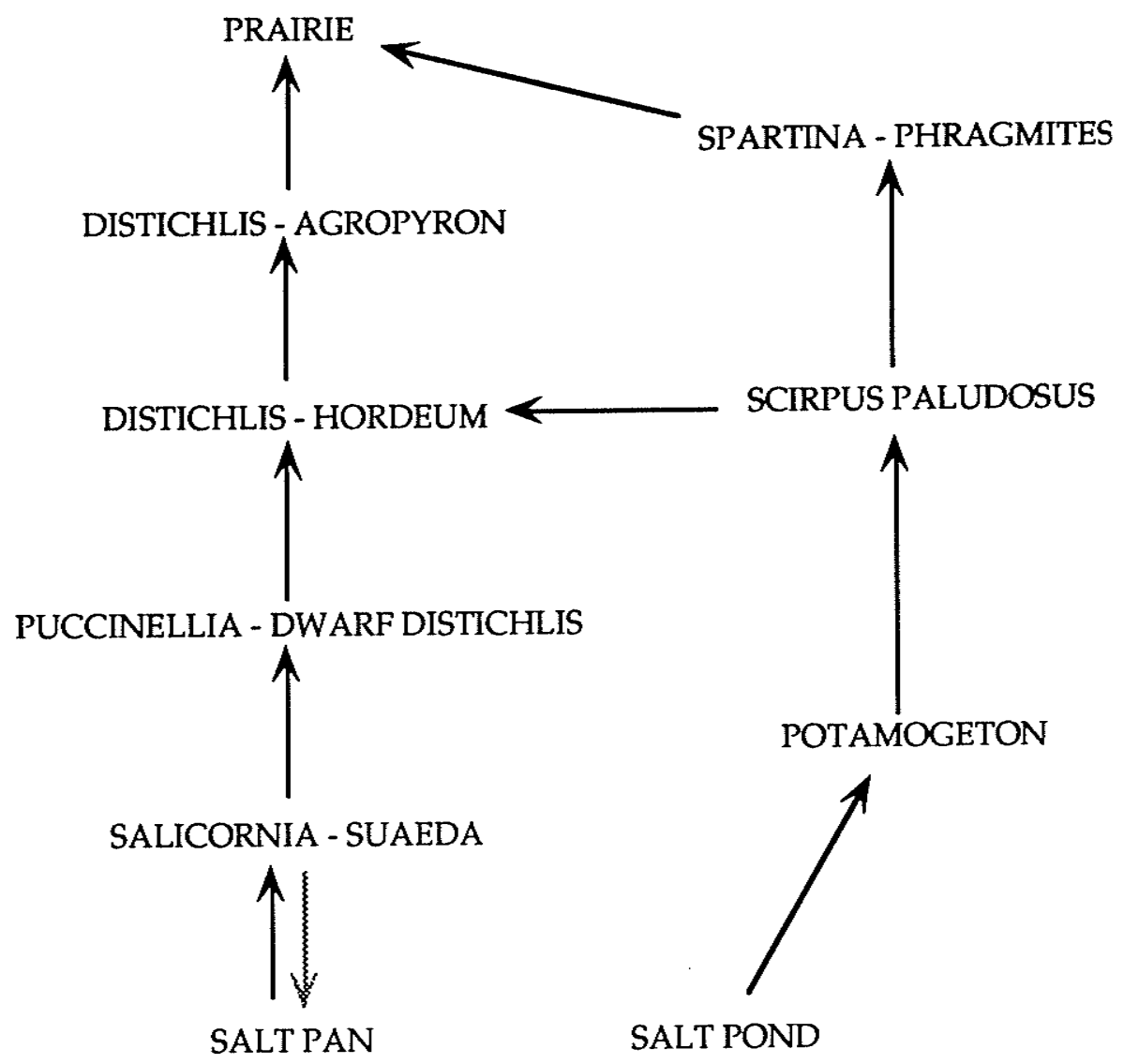

A hypothetical scheme of vegetational dynamics of sulfate dominated saline soils of eastern South Dakota (adapted from Ungar 1970). 


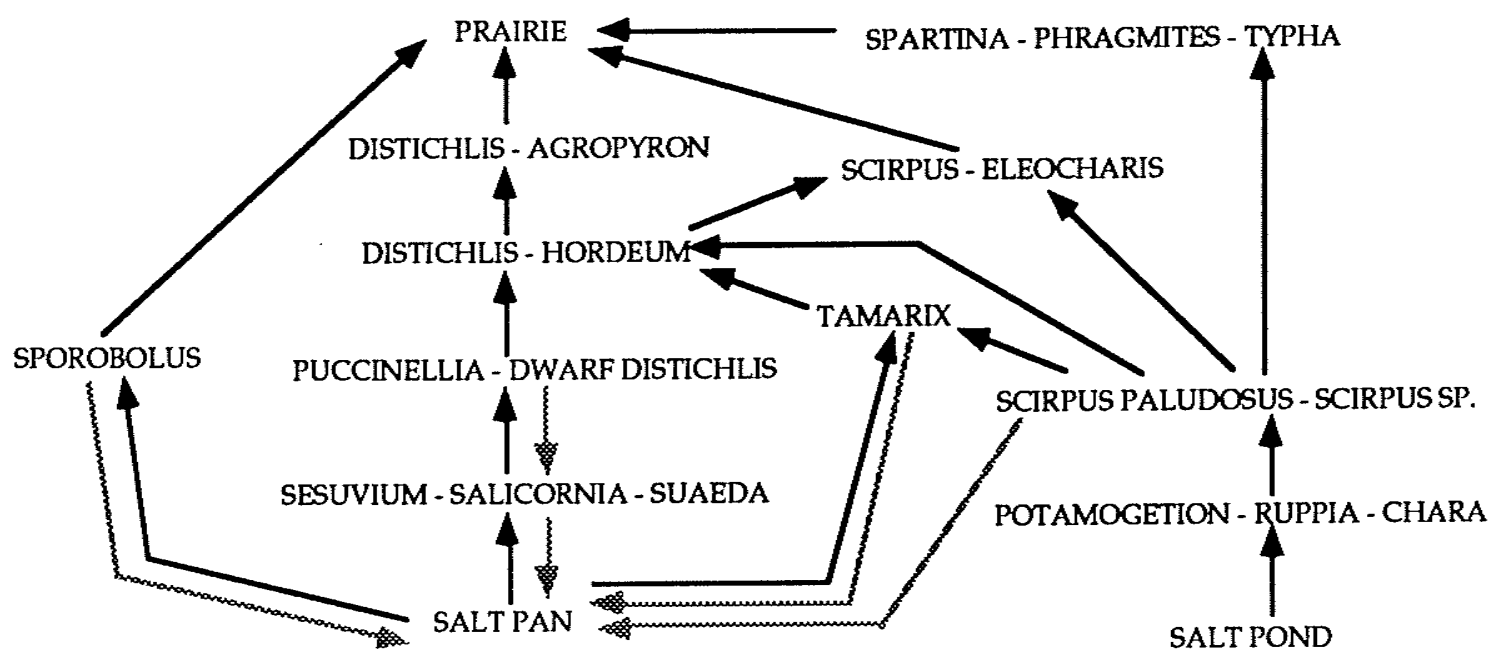

A scheme for vegetational dynamics of inland saline marshes of the prairie region of North America (adapted from Ungar 1972). 


\title{
Appendix C \\ Complete Species list of the Saline community and surrounding area.
}

Plants recorded in the saline meadows around saline flats, $1987,1988,1989$

\author{
Achillea millefolium \\ Agropyron smithii \\ Agropyron trachycaulum \\ Alnus rugosa \\ Ambrosia psilostachya var. coronopifolia \\ Amelanchier alnifolia \\ Arenaria lateriflora \\ Aster laevis \\ Aster pansus \\ Aster pauciflorus \\ Aster simplex \\ Atriplex patula var. hastata \\ Betula occidentalis \\ Bromus ciliatus \\ Calamagrostis inexpansa \\ Calamagrostis neglecta \\ Campanula rotundifolia \\ Carex aurea \\ Carex languinosa \\ Carex viridula \\ Castilleja miniata \\ Circium arvense \\ Comandra richardsonii \\ Distichlis stricta \\ Dodecatheon media \\ Elcocharis palustris \\ Eleocharis pauciflora \\ Epilobium angustifolium \\ Erigeron philadelphicus \\ Festuca saximontana \\ Fragaria virginiana \\ Galium boreale \\ Glaux maritima \\ Grindelia squarrosa \\ Helianthus maximilianii \\ Heraculum lanatum \\ Hierochloe odorata \\ Hordeum jubatum \\ Juncus balticus var. littoralis \\ Juncus compressus \\ Juniperous communis \\ Lathyrus palustris \\ Lilium philadelphicum \\ Luzula sp. \\ Melilotus officinale \\ Phragmites australis \\ Picea glauca \\ Plantago maritima \\ Poa compressa \\ Poa palustris \\ Populus tremuloides \\ Potentilla anserina \\ Primula mistassinica. \\ Puccinellia nuttalliana \\ Ranunculus cymbalaria \\ Ribes oxyacanthoides \\ Rosa acicularis
}


Salicornia rubra

Scirpus americanus

Scirpus paludosa

Senecio integeriumus

Shepherdia canadersis

Sisyrinchium montanum

Smilacina stellata

Solidago canadensis

Sonchus arvensis

Spartina gracilis

Spergularia marina

Sphenopholis obtusata

Stellaria longifolia

Suaeda depressa

Symphoricarpus albus

Thalictrum dasycarpum

Triglochin maritima

Viola sp.

Zizia aptera

Zygadenus elegans 
Plants found on the Spruce dominated ridges around the salt flats, August 1988

Achellia millefolium

Agropyron sp

Alnus rugosa

Antennaria parvafioia

Aralia nudicaulus

Arctium lappa

Arctostaphylus uva-ursi

Aster leavis

Betula glandulifera

Betula papyrifera

Carax spp

Comandra richardsiana

Cornus alba

Cornus canadensis

Crepis sp.

Cypripedium calceolus

Epilobium angustiflium

Equisetum arvense

Fragaaria virginiana

Galium boreale

Galium trifidum

Habinarea sp

Hilowcomium splendens

Juncus balticus

Juniperus communus

Lathyrus sp

Linnaea borealis

Maianthemum canadense

Monesus uniflora

Monotropa uniflora

Oxycoccus palustris

Petasites palmaatus

Pleurosium shruberi

Pyrola rotundifolia

Pyrola secunda

Ribes oxyacanthoides

Rosa acicularis

Rubus idaeus

Rubus pubescens

Sheperdia canadensis

Solidago sp

Symphorocarpos alba

Taraxicum sp.

Thalictrum venulosum

Trientalis borealis

Vaccinium $s p$

Vibernum rafinesquianum

Vicia spp.

Viola spp. 


\section{Appendix D}

\section{Summary of environmental variables among associations}

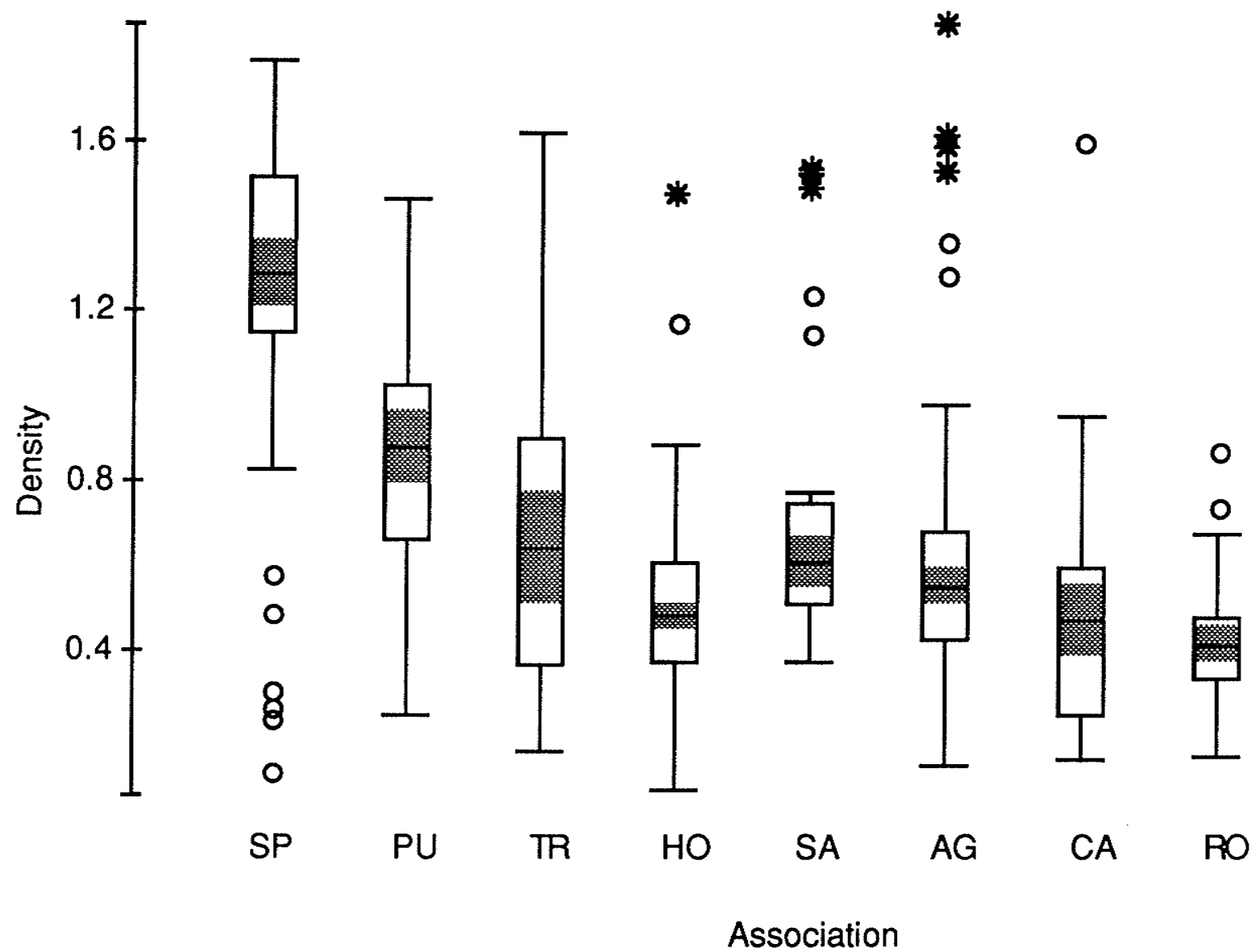

Boxplots summarizing soil density variation among associations. Shaded areas represent the $95 \%$ confidence interval of the median. Boxes represent the interquartile range; the horizontal line within each box is the median. Whiskers extend from the box to the nearest point within $\pm 1.5 *$ interquartile range. Circles represent outliers less than $\pm 3.0 *$ interquartile range and stars are outliers greater than $\pm 3.0 *$ interquartile range. Associations: SP - Salt Pan, PU - Puccinellia, TR - Triglochin, HO - Hordeum, SA Spartina, AG - Agropyron, CA - Calamagrostis, RO - Rosa. 


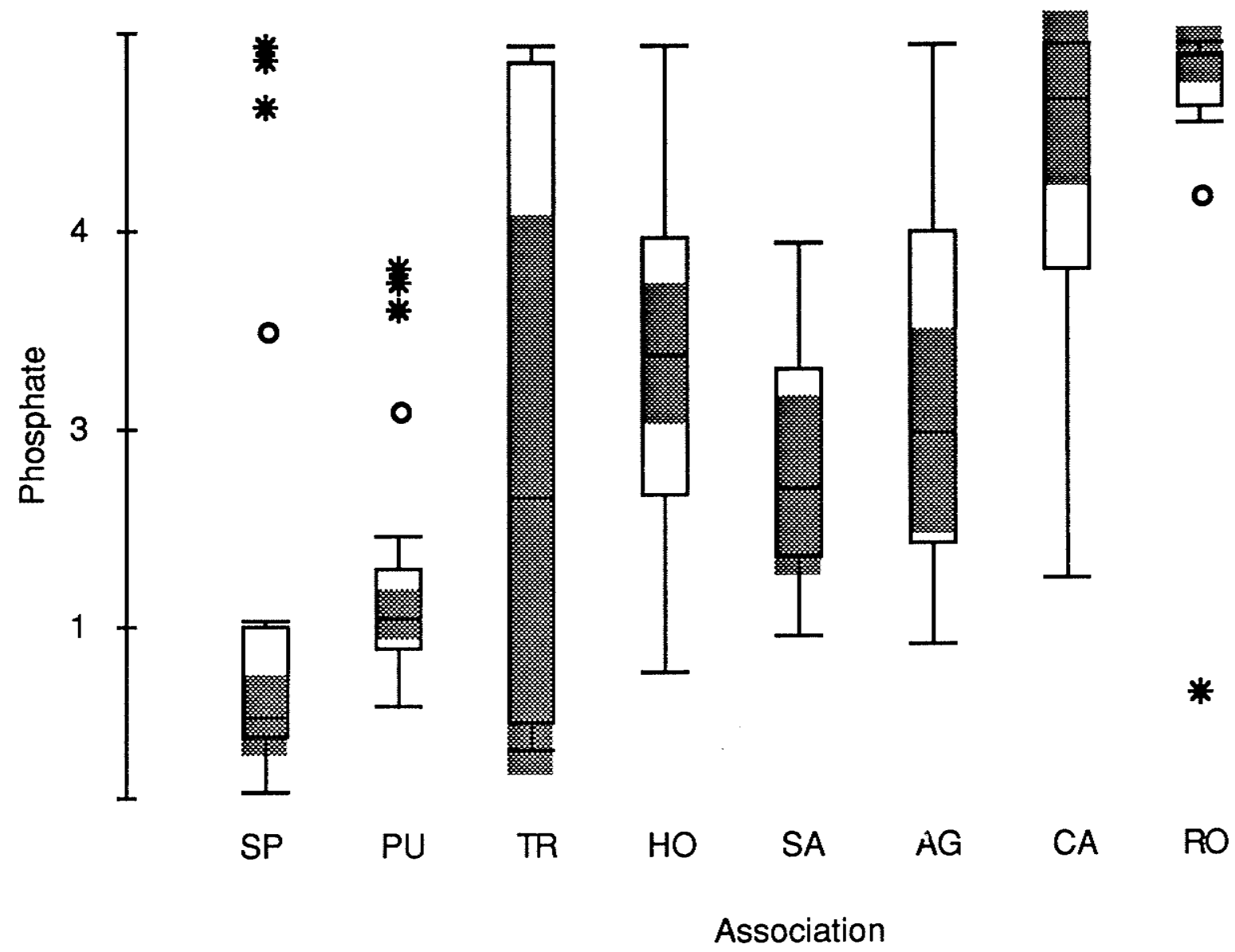

Boxplots summarizing soil phosphate (ppm) variation among associations. Shaded areas represent the $95 \%$ confidence interval of the median. Boxes represent the interquartile range; the horizontal line within each box is the median. Whiskers extend from the box to the nearest point within $\pm 1.5 *$ interquartile range. Circles represent outliers less than \pm $3.0 *$ interquartile range and stars are outliers greater than $\pm 3.0 *$ interquartile range. Associations: SP - Salt Pan, PU - Puccinellia, TR - Triglochin, HO - Hordeum, SA Spartina, AG - Agropyron, CA - Calamagrostis, RO - Rosa. 


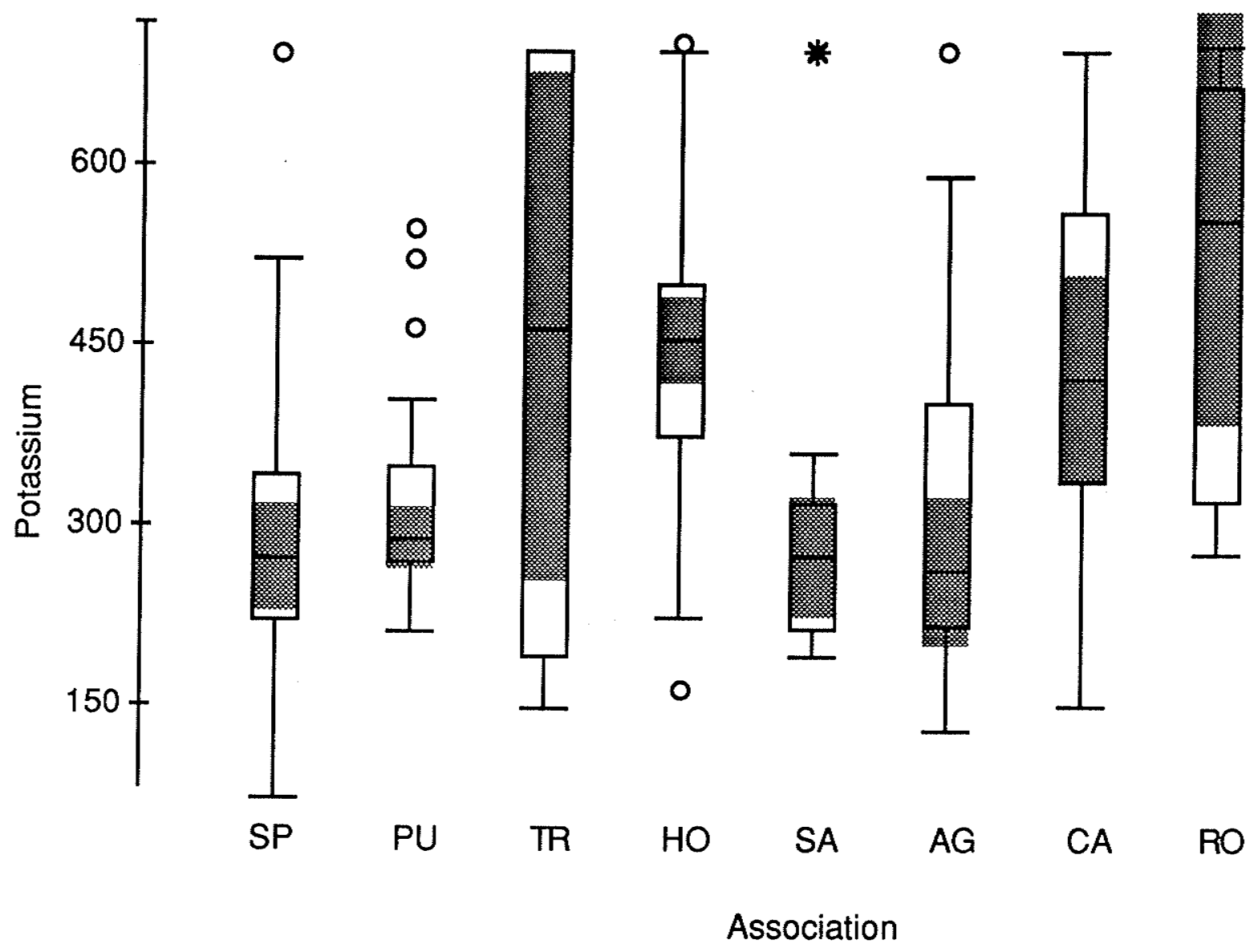

Boxplots summarizing soil potassium (ppm) variation among associations. Shaded areas represent the $95 \%$ confidence interval of the median. Boxes represent the interquartile range; the horizontal line within each box is the median. Whiskers extend from the box to the nearest point within $\pm 1.5 *$ interquartile range. Circles represent outliers less than \pm $3.0 *$ interquartile range and stars are outliers greater than $\pm 3.0 *$ interquartile range. Associations: SP - Salt Pan, PU - Puccinellia, TR - Triglochin, HO - Hordeum, SA Spartina, AG - Agropyron, CA - Calamagrostis, RO - Rosa. 


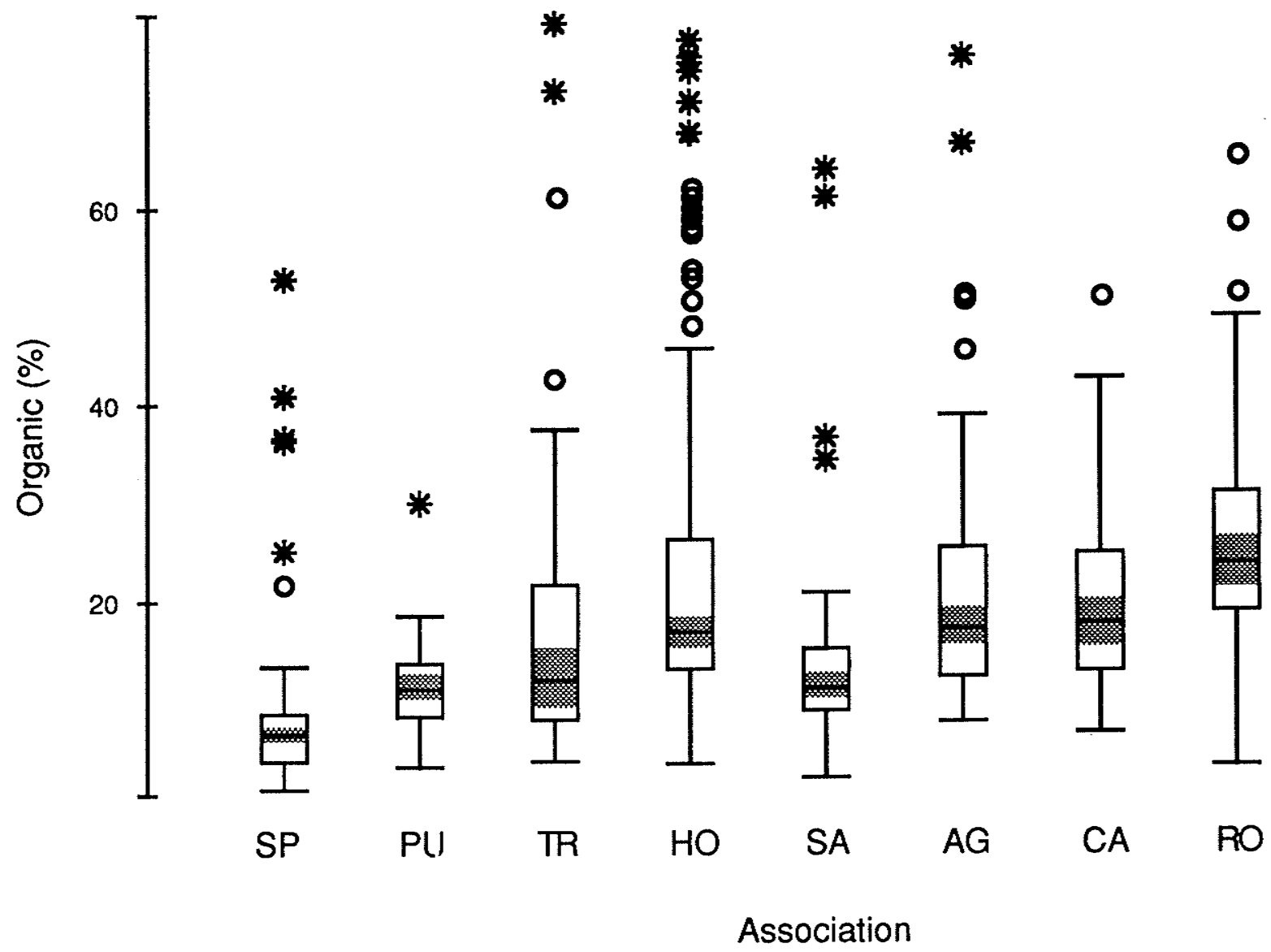

Boxplots summarizing soil organic content $(\%)$ variation among associations. Shaded areas represent the $95 \%$ confidence interval of the median. Boxes represent the interquartile range; the horizontal line within each box is the median. Whiskers extend from the box to the nearest point within $\pm 1.5 *$ interquartile range. Circles represent outliers less than $\pm 3.0 *$ interquartile range and stars are outliers greater than $\pm 3.0 *$ interquartile range. Associations: SP - Salt Pan, PU - Puccinellia, TR - Triglochin, HO Hordeum, SA - Spartina, AG - Agropyron, CA - Calamagrostis, RO - Rosa. 


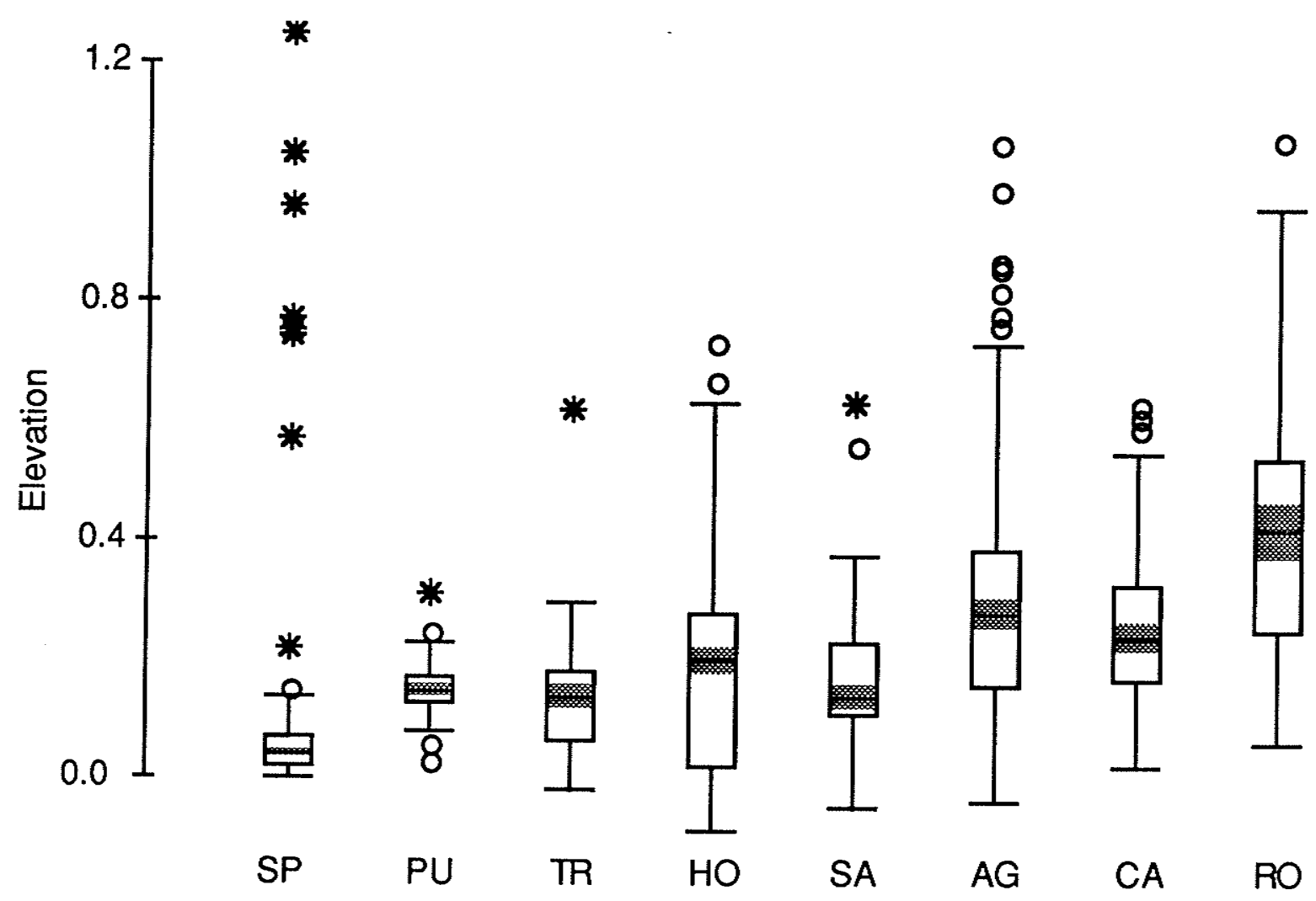

Association

Boxplots summarizing relative elevation (m) variation among associations. Shaded areas represent the $95 \%$ confidence interval of the median. Boxes represent the interquartile range; the horizontal line within each box is the median. Whiskers extend from the box to the nearest point within $\pm 1.5 *$ interquartile range. Circles represent outliers less than \pm $3.0 *$ interquartile range and stars are outliers greater than $\pm 3.0 *$ interquartile range. Associations: SP - Salt Pan, PU - Puccinellia, TR - Triglochin, HO - Hordeum, SA Spartina, AG - Agropyron, CA - Calamagrostis, RO - Rosa. 


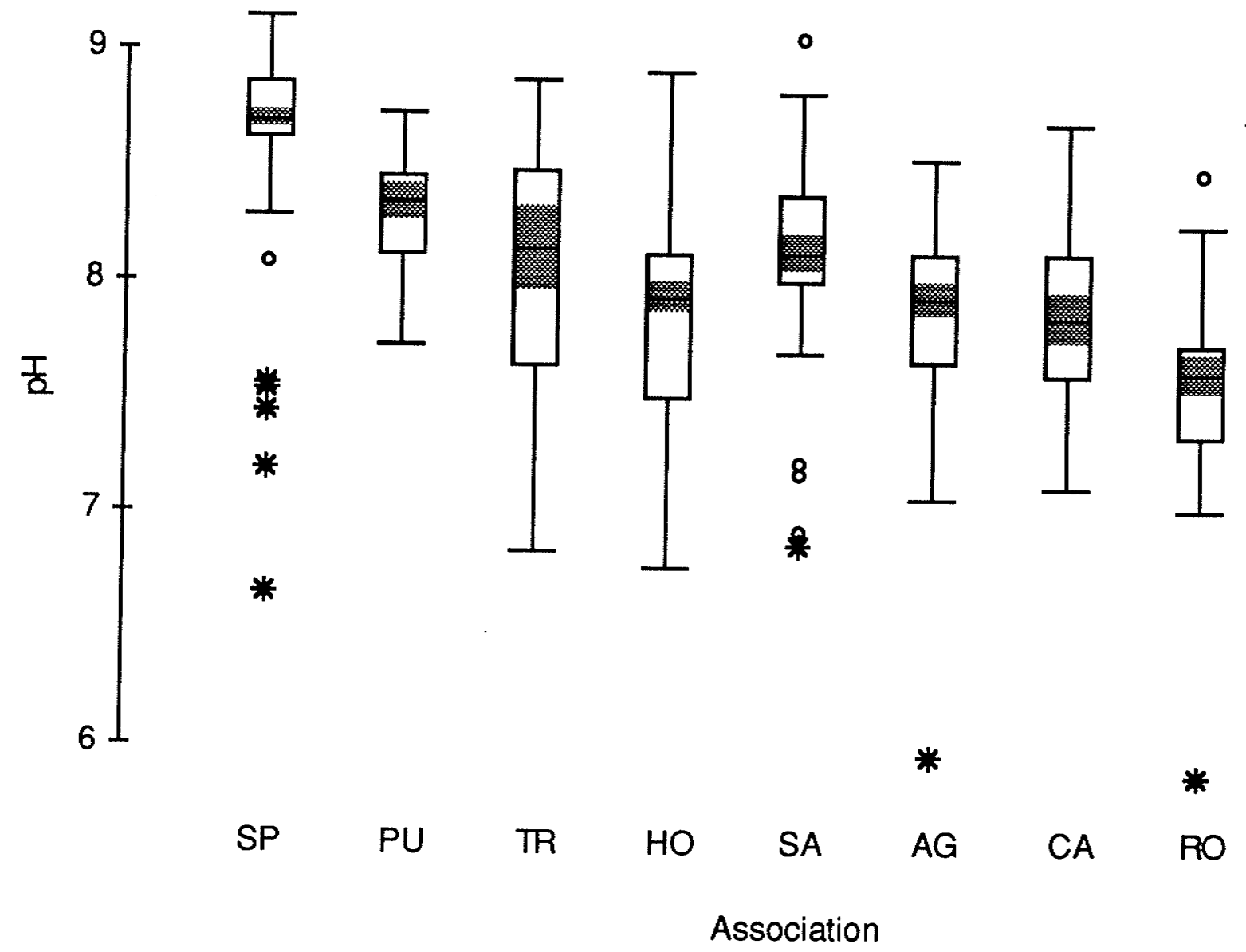

Boxplots summarizing soil $\mathrm{pH}$ variation among associations. Shaded areas represent the $95 \%$ confidence interval of the median. Boxes represent the interquartile range; the horizontal line within each box is the median. Whiskers extend from the box to the nearest point within $\pm 1.5 *$ interquartile range. Circles represent outliers less than $\pm 3.0 *$ interquartile range and stars are outliers greater than $\pm 3.0 *$ interquartile range. Associations: SP - Salt Pan, PU - Puccinellia, TR - Triglochin, HO - Hordeum, SA Spartina, AG - Agropyron, CA - Calamagrostis, RO - Rosa. 